Prepared in cooperation with the Bureau of Land Management

\title{
A 30-Year Chronosequence of Burned Areas in Arizona- Effects of Wildfires on Vegetation in Sonoran Desert Tortoise (Gopherus morafkai) Habitats
}

\section{Open-File Report 2015-1060}

\section{U.S Departinient of the interior U.S. Geological Surver}


Cover: Photograph showing burned habitat for the Sonoran Desert Tortoise (Gopherus morafkai) within the perimeter of the Gost Fire, Maricopa County, Arizona. This site burned in 2005 and is representative of burned areas in the Arizona Upland subdivision of the Sonoran Desert. The burned saguaro cactus

(Carnegiea gigantea) is evident by scarring (beige) and charring (blackened) at the base and is surrounded by several species of short-lived perennials, as well as a few long-lived perennials that persisted through the fire. Photograph taken by Felicia Chen, U.S. Geological Survey, October 24, 2013. 


\section{A 30-Year Chronosequence of Burned Areas in Arizona- Effects of Wildfires on Vegetation in Sonoran Desert Tortoise (Gopherus morafkai) Habitats}

By Daniel F. Shryock, Todd C. Esque, and Felicia C. Chen

Prepared in cooperation with the Bureau of Land Management

Open-File Report 2015-1060

U.S. Department of the Interior

U.S. Geological Survey 


\section{U.S. Department of the Interior \\ SALLY JEWELL, Secretary}

\section{U.S. Geological Survey \\ Suzette M. Kimball, Acting Director}

U.S. Geological Survey, Reston, Virginia: 2015

For more information on the USGS—-the Federal source for science about the Earth, its natural and living resources, natural hazards, and the environment-visit http://www.usgs.gov/ or call 1-888-ASK-USGS (1-888-275-8747).

For an overview of USGS information products, including maps, imagery, and publications, visit http://www.usgs.gov/pubprod/.

To order USGS information products, visit http://store.usgs.gov/.

Any use of trade, firm, or product names is for descriptive purposes only and does not imply endorsement by the U.S. Government.

Although this information product, for the most part, is in the public domain, it also may contain copyrighted materials as noted in the text. Permission to reproduce copyrighted items must be secured from the copyright owner.

Suggested citation:

Shryock, D.F., Esque, T.C., and Chen, F.C., A 30-year chronosequence of burned areas in Arizona-Effects of wildfires on vegetation in Sonoran Desert Tortoise (Gopherus morafkai) habitats: U.S. Geological Survey Open-File Report 2015-1060, 61 p., http://dx.doi.org/10.3133/ofr20151060.

ISSN 2331-1258 (online) 


\section{Contents}

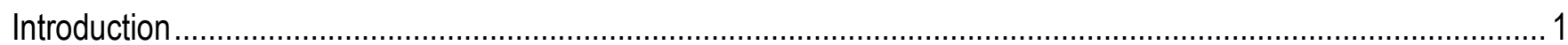

Sonoran Desert Tortoises and Wildfire .................................................................................................

Environmental Determinants of Vegetation Recovery Following Desert Wildfires.............................................

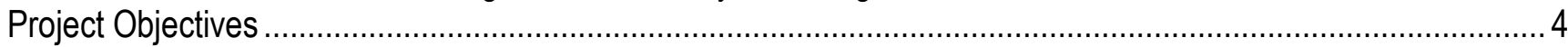

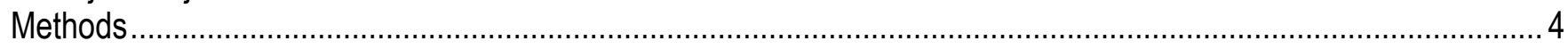

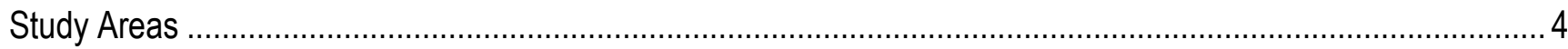

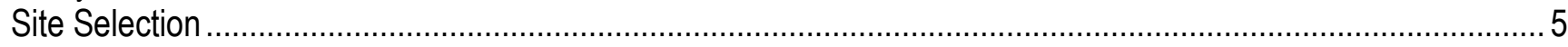

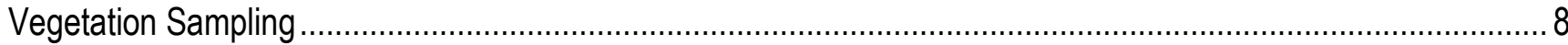

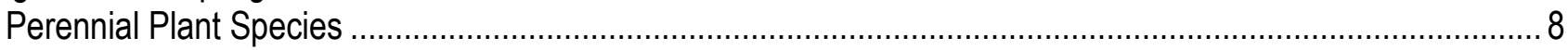

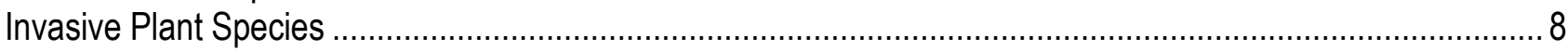

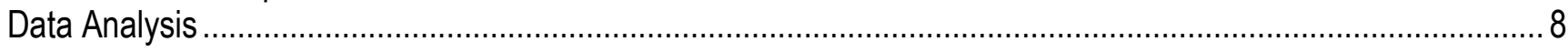

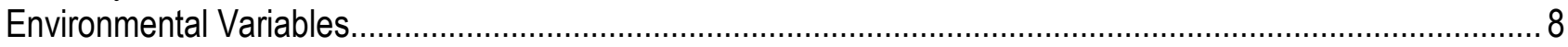

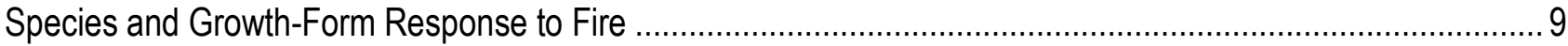



Landscape Scale Vegetation Recovery.................................................................................................... 11

Wildfire Effects on Sonoran Desert Tortoise Food and Cover Species ........................................................11

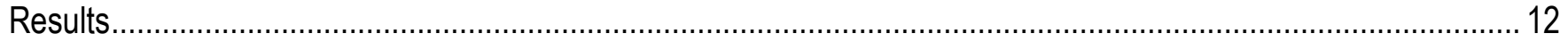

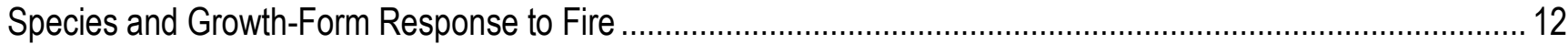

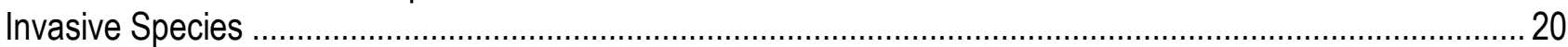

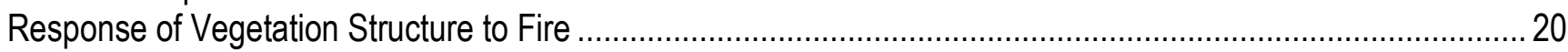

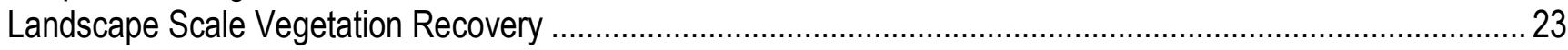

Long-Term Influences of Fire on Desert Tortoise Habitat ......................................................................... 26

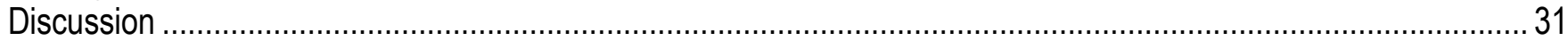

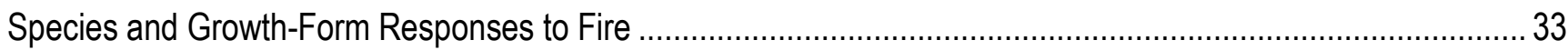

Vegetation Recovery from Fire at the Structural and Landscape Scales .......................................................34

Perspectives on Post-Fire Vegetation Change and the Sonoran Desert Tortoise ...............................................36

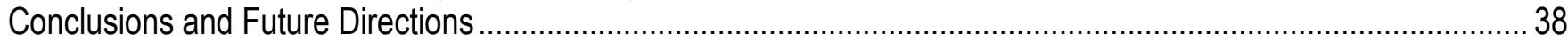







Appendix A. Model Averaged Coefficients............................................................................................... 47

Appendix B. Sonoran Desert Tortoise Food and Cover Plants ……............................................................. 49

Appendix C. Cover and Density for Perennial Plant Species .............................................................................. 53

Appendix D. Frequencies of Invasive Annual Species Observed .................................................................... 61 


\section{Figures}

Figure 1. Perimeters of fires sampled in the Sonoran Desert ecoregion of central Arizona, 2013 ........................ 7

Figure 2. Examples of fire boundary development from remote sensing of the White Canyon fire (1995; left image) and the Nuke fire (2005; right image)

Figure 3. Principal response curves showing the rate of change relative to unburned areas as a function of TimeSince-Fire (TSF) in burned (a) species composition and (b) growth form composition.

Figure 4. Effect plot displays for modal-averaged parameters in candidate model sets predicting cover of individual growth forms with respect to fire, topography, climate, or Time-Since-Fire.

Figure 5. Effect plot displays of model-averaged parameters in candidate model sets for (a) vegetation percentage cover, and (b) vegetation density with respect to burn status, topography, climate, or Time-Since-Fire

Figure 6. Effect plot displays of model-averaged parameters in candidate model sets for average vegetation height with respect to burn status, topography, climate, or time-since-fire 23

Figure 7. Linear regression models comparing the influence of Time-Since-Fire (TSF, shown as year of fire) and environmental variables on the ratios of burned-to- unburned vegetation cover (a), height (b), and density (c)

Figure 8. Burned/unburned ratios of percentage cover for perennial plant species aggregated into tortoise-use categories: cover species (left panel) and food species (right panel)

Figure 9. Outlying Mean Index (OMI) ordination analysis of perennial species response to fire through time (Time-Since-Fire, or TSF).

Figure 10. Breadth of perennial species distributions in relation to Time-Since-Fire (x-axis, left) and burn status (y-axis, right)

Figure 11. Conceptual model showing the relative influence of environmental filters and Time-Since-Fire (TSF) in shaping the response of community-scale vegetation attributes (cover, height, density) and perennial growth forms to fire, based on a chronosequence of once-burned areas ranging in TSF from 8 to 33 years

\section{Tables}

Table 1. List of burned sites sampled in Arizona, 2013.

Table 2. Environmental variables extracted at each transect location and included in analyses of the effects of fire on Sonoran Desert perennial vegetation

Table 3. Percentage relative cover by plant species averaged across 13 fires with a range in Time-Since-Fire (8-33 years) and spanning the Arizona Upland subdivision of the Sonoran Desert, Arizona........ 13 Table 4. Influence of burn treatment, topography, and climate on post-fire composition of species and growth forms in the Sonoran Desert based on PerMANOVA tests 14

Table 5. Candidate models ranked by bias-corrected Akaike's Information Criterion (AICC) showing the influence of fire, topography, and climate on perennial growth form cover

Table 6. Candidate model sets $(\triangle \mathrm{AIC}<<4)$ showing the influence of fire, topography, and climate on vegetation cover, height, and density, respectively.....

Table 7. Linear regression models explaining the ratio of burned to unburned vegetation cover, height, and density, ranked by bias-corrected Akaike's Information Criterion (AICC).

Table 8. Tortoise food species (derived from Van Devender and others, 2002) observed on burned and unburned plots at 13 study areas in the Arizona Upland Subdivision of the Sonoran Desert, Arizona 27

Table 9. Indicator species analysis for perennial plant species partitioned by burn status (burned or unburned). .. 28 


\section{Conversion Factors}

International System of Units to Inch/Pound

\begin{tabular}{lcl}
\hline \multicolumn{1}{c}{ Multiply } & \multicolumn{1}{c}{ By } & \multicolumn{1}{c}{ To obtain } \\
\hline & Length & \\
\hline centimeter $(\mathrm{cm})$ & 0.3937 & inch (in.) \\
millimeter $(\mathrm{mm})$ & 0.03937 & inch (in.) \\
meter $(\mathrm{m})$ & 3.281 & foot (ft) \\
kilometer $(\mathrm{km})$ & 0.6214 & mile (mi) \\
kilometer $(\mathrm{km})$ & 0.5400 & mile, nautical (nmi) \\
meter $(\mathrm{m})$ & 1.094 & yard (yd) \\
\hline & Area & \\
\hline square meter $\left(\mathrm{m}^{2}\right)$ & 0.0002471 & acre \\
square kilometer $\left(\mathrm{km}^{2}\right)$ & 247.1 & acre \\
square meter $\left(\mathrm{m}^{2}\right)$ & 10.76 & square foot $\left(\mathrm{ft}^{2}\right)$ \\
square kilometer $\left(\mathrm{km}^{2}\right)$ & 0.3861 & square mile $\left(\mathrm{mi}^{2}\right)$ \\
\hline
\end{tabular}

Temperature in degrees Celsius $\left({ }^{\circ} \mathrm{C}\right)$ may be converted to degrees Fahrenheit $\left({ }^{\circ} \mathrm{F}\right)$ as ${ }^{\circ} \mathrm{F}=\left(1.8 \times{ }^{\circ} \mathrm{C}\right)+32$.

\section{Datums}

Horizontal coordinate information is referenced to the North American Datum of 1983 (NAD 83).

Vertical coordinate information is referenced to the North American Vertical Datum of 1988 (NAVD 88).

Elevation, as used in this report, refers to distance above the vertical datum.

\section{Abbreviations}

$\begin{array}{ll}\text { ANOVA } & \text { Analysis of Variance } \\ \text { AICC } & \text { bias-corrected Akaike's Information Criterion } \\ \text { BLM } & \text { Bureau of Land Management } \\ \text { ISA } & \text { Indicator Species Analysis } \\ \text { LME } & \text { Linear Mixed-Effects models } \\ \text { OMI } & \text { Outlying Mean Index ordination } \\ \text { PerMANOVA } & \text { permutational Multivariate Analysis of Variance using distance matrices } \\ \text { PRC } & \text { Principal Response Curve } \\ \text { PRISM } & \text { Parameter-elevation Relationships on Independent Slopes Model } \\ \text { RDA } & \text { Redundancy Analysis } \\ \text { TSF } & \text { Time-Since-Fire } \\ \text { UTM } & \text { Universal Transverse Mercator }\end{array}$


This page left intentionally blank 


\title{
A 30-Year Chronosequence of Burned Areas in Arizona- Effects of Wildfires on Vegetation in Sonoran Desert Tortoise (Gopherus morafkai) Habitats
}

\author{
By Daniel F. Shryock, Todd C. Esque, and Felicia C. Chen
}

\section{Introduction}

Fire is widely regarded as a key evolutionary force in fire-prone ecosystems, with effects spanning multiple levels of organization, from species and functional group composition through landscape-scale vegetation structure, biomass, and diversity (Pausas and others, 2004; Bond and Keeley 2005; Pausas and Verdu, 2008). Ecosystems subjected to novel fire regimes may experience profound changes that are difficult to predict, including persistent losses of vegetation cover and diversity (McLaughlin and Bowers, 1982; Brown and Minnich, 1986; Brooks, 2012), losses to seed banks (Esque and others, 2010a), changes in demographic processes (Esque and others, 2004; DeFalco and others, 2010), increased erosion (Soulard and others, 2013), changes in nutrient availability (Esque and others, 2010b), increased dominance of invasive species (Esque and others, 2002; Brooks and others, 2004), and transitions to alternative community states (Davies and others, 2012). In the deserts of the Southwestern United States, fire size and frequency have increased substantially over the last several decades because of an invasive grass/fire feedback cycle (Schmid and Rogers, 1988; D'Antonio and Vitousek, 1992; Swantek and others, 1999; Brooks and Matchett, 2006; Esque and others, 2010a), in which invasive annual species are able to establish fuel loads capable of sustaining large-scale wildfires following years of high rainfall (Esque and Schwalbe, 2002). Native perennial vegetation is not welladapted to fire in these environments, and widespread, physiognomically dominant species such as creosote bush (Larrea tridentata), Joshua tree (Yucca brevifolia), giant saguaro cactus (Carnegiea gigantea), and paloverde (Parkinsonia spp.) may be reduced or eliminated (Brown and Minnich, 1986; Esque and others, 2006; DeFalco and others, 2010), potentially affecting wildlife populations including the Sonoran and federally threatened Mojave Desert Tortoises (Gopherus morafkai and Gopherus agassizii, respectively; Brooks and Esque, 2002; Esque and others, 2003; Drake and others, in press).

\section{Sonoran Desert Tortoises and Wildfire}

Sonoran Desert Tortoises generally occupy the Arizona Upland and the Lower Colorado River Valley vegetation subdivisions of the Sonoran Desert, and neither vegetation type is thought to have evolved with wildfire as a common phenomenon (Esque and others, 2003, 2013); however, one recent large fire has resulted from large fuel loads created by native annuals in the Lower Colorado River Valley subdivision of the Sonoran Desert (Esque and others, 2013). Although desert wildfires likely occurred across the Southwestern United States for millennia, unforested desert regions do not provide records of such phenomena (Esque and Schwalbe, 2002). The historical record of newspapers and 
scientific literature provided only rare documentation of desert fires until the early 1980s (Rogers and Vint, 1987; Bahre, 1991). Furthermore, historical fires do not appear to have been large or widespread in the Arizona Upland subdivision of the Sonoran Desert because the nominal species of the regionsaguaro cactus (Carnegiea gigantea) and paloverde (Parkinsonia spp.) - do not respond well to fire and require centuries to return; yet they are widespread and their distributions do not indicate losses to wildfires.

An apparent increase in desert wildfires post-1980 may correspond to a regional climate shift in the late 20th century that resulted in the wettest period in recorded history for the Southwestern United States (Hereford and others, 2006). In the late 1970s and early 1980s, El Niño/La Niña phenomena changed from obscure concepts found in ecology textbooks to common topics for the evening weather on media outlets. These wet/dry weather patterns, coupled with the invasion of Mediterranean brome grasses (Bromus rubens and Bromus tectorum) that engulfed the entire Western United States over the last 150 years (Brooks and others, 2004) and increased ignitions brought on by a surge in human populations, led to increased wildland fire frequencies (Brooks and Matchett, 2006). Heavy precipitation events facilitated widespread and abundant production of the winter invasive annual grass, red brome (Bromus rubens). Because red brome is less susceptible to decomposition than native annual species, a build-up of persistent fine fuels following the wet period resulted in several fires in Sonoran Desert Tortoise habitat that were documented in the literature (McLaughlin and Bowers, 1982; Cave and Patten, 1984; McAuliffe, 1995; Brooks and Esque, 2002; Esque and others, 2003; Nussear and Tuberville, 2014).

Earlier studies of desert tortoise habitat recorded losses to tortoise populations because of acute exposure to fire and fire-caused mortality has occurred in all size classes of tortoises, whether in the Mojave or Sonoran Deserts (Esque and others, 2003). However, questions have been raised about how potential long-term changes in desert tortoise habitat caused by fire affect surviving tortoises. Hypothetically, changes in food availability and cover for thermal/predator protection could influence localized tortoise populations (Esque and others, 2003; Snyder, 2014; Drake and others, in press). Recent research has shed new light on these hypotheses, and will be explored in the context of new information from the present study in the section, "Discussion."

\section{Environmental Determinants of Vegetation Recovery Following Desert Wildfires}

The short-term effects of wildfire in Sonoran Desert vegetation communities are previously documented in several studies (McLaughlin and Bowers, 1982; Cave and Patton, 1984; Brown and Minnich 1986) and include reductions in vegetation cover and losses of dominant shrub, tree, and cacti species, which rarely resprout. However, only one existing study has examined long-term effects of wildfire in Arizona Upland vegetation (Alford, 2001) - the primary habitat for the Sonoran Desert Tortoise. Hence, many aspects of post-fire vegetation recovery remain poorly understood in this and similar desert ecosystems (Abella, 2009; Engel and Abella, 2011). In particular, knowledge concerning the degree to which topographic and climatic gradients influence vegetation recovery patterns is extremely limited, although growing evidence indicates that such factors drive variability in fire severity and vegetation recovery in non-desert environments (Grace and Keeley, 2006; Diouf and others, 2012; Levick and others, 2012; Clarke and others, 2014).

The "environmental-filter" hypothesis stipulates that post-fire vegetation recovery primarily is influenced by variations in abiotic conditions, including climatic, topographic, or edaphic gradients (Keeley and others, 2005). Therefore, individual species and vegetation community responses to fire are sorted along spatially variable environmental gradients that together account for most of the variability in post-fire vegetation structure and composition. In contrast, the "fire-interval" hypothesis stipulates 
that variation in the fire-return interval (that is, Time-Since-Fire [TSF] or recovery time) is the primary determinant of species and vegetation community recovery (Bond and van Wilgen, 1996; Keeley and others, 2005). Under this hypothesis, species composition is expected to have a directional response with increasing TSF, becoming either more or less similar to pre-burned conditions. Directional responses are repeatable patterns of species turnover that may result from intraspecific differences in species traits (for example, resprouting and [or] reproductive potential, growth rate, and generation time) or from biotic interactions, including competition and facilitation - also referred to as "autogenic" or "self-regulatory" processes (Barbour and others, 1999; Keeley and others, 2005). In extreme cases, fire may create an alternative stable vegetation state that is subsequently maintained by biotic interactions; as a result, vegetation becomes less similar to pre-burned conditions through time (Davies and others, 2012). The two hypotheses need not be viewed as mutually exclusive, however, and the importance of fire-interval and environmental-filtering processes may vary across different attributes of the vegetation community (for example, vegetation cover and density), across different levels of organization (for example, species composition and overall cover), or at different temporal scales. Understanding the relative influences of TSF and abiotic conditions is important for managing burned desert landscapes, particularly in terms of prioritizing restoration activities or evaluating effects on habitat for threatened species such as the Sonoran Desert Tortoise.

Evidence from arid environments may support both the environmental-filter and fire-interval hypotheses. For example, vegetation cover of burned areas in the Mojave Desert is strongly correlated with TSF (Abella, 2009; Vamstad and Rotenberry, 2010), and species composition of burned Larrea tridentata communities has shown partial return to pre-fire vegetation composition following several decades of recovery (Engel and Abella, 2011). Hence, evidence supports the importance of TSF in shaping long-term vegetation recovery following desert wildfires. However, regional climatic gradients also are known to determine the level of post-fire resprouting for perennial species within arid and semiarid environments (Clarke and others, 2005; Pausas and Bradstock, 2007; Nano and Clarke, 2011), with long-term consequences for community structure (Arnan and others, 2007). Additionally, elevation and soil characteristics have been found to explain a large proportion of variability in burned species composition across vegetation communities in the Mojave Desert (Engel and Abella, 2011), whereas in the Sonoran Desert, xeroriparian vegetation communities recover faster than drier uplands (Esque and others, 2013). Empirical evidence, therefore, suggests that abiotic conditions of burned sites also are a strong determinant of post-fire vegetation recovery in deserts.

Although existing evidence supports both hypotheses, the primary questions remain-Is postfire vegetation influenced more by environmental filters or TSF, and do these influences vary across different levels of community organization? At present, this is difficult to evaluate because most studies have focused on the short-term response of desert vegetation to fire (for example, McLaughlin and Bowers, 1982; Cave and Patton, 1984; Brooks and Matchett, 2003), or, if including longer TSFs, have involved relatively few sites or limited geographic extents (for example, Minnich, 1995; Turner and others, 2010; Vamstad and Rotenberry, 2010; Steers and Allen, 2011; but see Engel and Abella, 2011). Studies also have adopted experimental designs that minimize environmental heterogeneity in order to isolate the effects of TSF (for example, Callison and others, 1985; Alford, 2001), thereby ignoring the influence of abiotic conditions. Regional scale analyses incorporating both environmental heterogeneity and a range in TSF are required to parse out the relative influence of abiotic conditions and recovery time. 
The Sonoran Desert is an important environment within which to evaluate the relative strengths of the fire-interval and environmental-filter hypotheses to predict post-fire vegetation recovery. First, the region is subjected to a novel fire regime, with an increased frequency of large, invasive-speciesdriven wildfires occurring over the last several decades (Schmid and Rogers, 1988; Alford, 2001). Therefore, the vegetation response — whether time-dependent or driven by environmental filters - is observed to be highly pronounced. Second, both biotic and abiotic factors exert a powerful influence on Sonoran Desert vegetation. Perennial species are strongly differentiated by life-history strategy and consequent demographic patterns (for example, reproductive rate; Goldberg and Turner, 1986) that, along with facilitative and competitive interactions (Butterfield and others, 2010), drive temporal population dynamics. At the same time, Sonoran Desert vegetation communities - particularly the wellknown foothill paloverde/saguaro cactus association - occupy a diverse landscape in which vegetation is structured by spatiotemporal climatic patterns (Medeiros and Drezner, 2012; Munson and others, 2012), along with fine-scale topographic and edaphic gradients (Parker, 1991; Turner and Brown, 1994). We, therefore, expect that each of these factors influences vegetation response to fire, but that the overall response will vary depending on whether abiotic conditions or TSF is the primary determinant.

\section{Project Objectives}

The objectives of this project were to analyze a chronosequence of sites replicated in time to compare the change between and within burned and nearby unburned areas. The goal of acquiring this information was to inform managers about vegetation recovery in relation to the use of habitat by the Sonoran Desert Tortoise. Because no fieldwork was conducted on Sonoran Desert Tortoises during this study, we draw on previous work to interpret our results in relation to vegetation changes that may affect how tortoises are able to use burned habitat. We used a space-for-time approach to evaluate the relative influences of abiotic conditions (climate and topography), and TSF on post-fire vegetation recovery in the Sonoran Desert. We sampled perennial vegetation from a chronosequence of 13 fires ranging from 8 to 33 years TSF and occupying a broad regional gradient. The analysis spans different levels of community organization, from responses of individual species and growth forms to landscapescale vegetation recovery patterns, and considers different vegetation attributes (cover, height, and density). We hypothesized that (1) species and growth form composition primarily would represent the filtering influence of abiotic conditions, whereas overall vegetation attributes (percentage cover, height, and density) would more strongly relate to TSF; and (2) differences between burned and unburned vegetation would persist at all levels of analysis. Finally, we discuss the ramifications of the vegetation changes that were quantified relative to habitat quality for the Sonoran Desert Tortoise.

\section{Methods}

\section{Study Areas}

The Sonoran Desert spans about 275,000 $\mathrm{km}^{2}$ in the Southwestern United States and Mexico and is considered to be the third largest desert in North America (MacMahon, 2000). Precipitation across much of the region is bimodal and nearly evenly split between winter and summer, but with annual precipitation ranging from less than 130 to more than $400 \mathrm{~mm}$ (Turner and Brown, 1994). Although at least five distinct vegetation subdivisions have been recognized within this ecoregion (Turner and Brown, 1994; MacMahon, 2000), we sampled vegetation from fires occurring in the Arizona Upland and Lower Colorado River Valley subdivisions of the Sonoran Desert. Arizona Upland vegetation is characterized by sub-trees (paloverde spp., mesquite spp. [Prosopis spp.], ironwood [Olneya tesota], 
crucifixion thorn [Canotia holacantha], and ocotillo [Fouquieria splendens]), along with shrubs (creosote bush, triangle-leaf bursage [Ambrosia deltoidea], acacia spp. [Acacia spp.], and jojoba [Simmondsia chinensis]), and the iconic saguaro cactus. Lower Colorado River Valley vegetation is dominated by shrubs (Larrea tridentata, Ambrosia spp., and brittlebush [Encelia farinosa]), with those sub-trees also found in the Arizona Upland primarily restricted to drainages. Various species of cacti (Cholla spp. [Cylindropuntia spp.], prickly pear [Opuntia spp.], and barrel cactus [Ferocactus spp.]) and grasses (galleta grass [Pleuraphis spp.], three-awns [Aristida spp.], grama grasses [Bouteloua spp.], and Muhly grasses [Muhlenbergia spp.]) occur in both subdivisions, but the dominant physiognomy is shrubland. Diverse spring and summer annual floras also are present in wetter years (Turner and Brown, 1994); however, only a few invasive annuals are considered in this report because of the short duration of the study and poor annual growth during this period.

The Arizona Upland subdivision of the Sonoran Desert has a mean annual precipitation of about $290 \mathrm{~mm}$ and mean summer temperatures of $29^{\circ} \mathrm{C}$ (Turner and Brown, 1994). Lower Colorado River Valley sites generally are lower in elevation and have less annual precipitation $(130 \mathrm{~mm})$, along with warmer summer temperatures (mean of $30^{\circ} \mathrm{C}$ ). Sonoran Desert soils are derived primarily from igneous materials, including granite, basalt, and rhyolitic tuff. Metamorphic schists and gneiss also are common along slopes, whereas conglomerate may occur in drainages (McMahon, 2000). Arizona Upland sites generally are mountainous and topographically complex, with steep gradients in elevation, slope, and aspect occurring over relatively small areas. Common geomorphic features include slopes, ridges, ballenas, bajadas, and washes.

\section{Site Selection}

Potential study areas were pre-screened by Bureau of Land Management (BLM) staff to identify prospects for a replicated chronosequence of burned areas across Sonoran Desert Tortoise habitats, primarily in the Arizona Upland subdivision of the Sonoran Desert (Turner and Brown, 1994; Nussear and Tuberville, 2014). Prospective study areas had to meet the criterion of providing a burned site and a comparable unburned site. The prospective study areas were communicated to U.S. Geological Survey staff, and we reconnoitered all sites to determine their value as study areas depending on these additional selection criteria:

1. Charcoal had to be present in the burned sites and absent in the unburned site on preliminary inspection;

2. Burn scars had to be discernible in remotely sensed satellite imagery from the year of the fire (for burned sites);

3. Topography (for example, elevation, slope, and aspect), geologic substrate, and soil texture had to be similar in both burned and unburned sites upon visual inspection; and

4. Unburned sites meeting the previous criteria had to be immediately adjacent to burned sites.

Based on field reconnaissance of 18 prospective sites in spring of 2013, we selected 13 sites meeting these criteria (table 1). Because of insufficient replication of the oldest sites on BLM properties, we secured permission and added sites to the study area that occurred on U.S. Forest Service lands. 
Table 1. List of burned sites sampled in Arizona, 2013.

[Coordinates are projected into Universal Transverse Mercator (UTM) Zone 12N, North American Datum of 1983 (NAD 83), and represent the midpoint of each digital fire polygon. Elevations reported are the average elevation of sampled transects within each fire]

\begin{tabular}{lclccrr}
\hline \multicolumn{1}{c}{ Fire name } & Year & $\begin{array}{c}\text { Ignition } \\
\text { date }\end{array}$ & $\begin{array}{c}\text { Area burned } \\
\text { (acres) }\end{array}$ & $\begin{array}{c}\text { UTM } \\
\text { easting }\end{array}$ & $\begin{array}{c}\text { UTM } \\
\text { northing }\end{array}$ & $\begin{array}{c}\text { Elevation } \\
\text { (meters) }\end{array}$ \\
\hline Wades & 1980 & June 17 & 753 & 339066 & 3769857 & 779 \\
Bootleg & 1980 & June 27 & 6,634 & 437359 & 3744201 & 900 \\
Hualapai & 1980 & August 11 & 281 & 232530 & 3858322 & 1,268 \\
Jacket & 1988 & July 2 & 9,018 & 447951 & 3738200 & 910 \\
Rock & 1989 & June 28 & 345 & 290490 & 3748608 & 1,005 \\
San Tan & 1993 & April 20 & 959 & 438446 & 3671582 & 542 \\
Harquahala & 1993 & July 14 & 3,876 & 286340 & 3747335 & 843 \\
White Canyon & 1995 & June 24 & 5,712 & 489983 & 3661172 & 807 \\
Harcuvar & 1999 & May 27 & 16,563 & 281244 & 3773413 & 850 \\
Arrastra & 1999 & June 18 & 2,621 & 209080 & 3831333 & 883 \\
Nuke & 2005 & May 21 & 565 & 311321 & 3698752 & 389 \\
Gost & 2005 & June 29 & 865 & 455153 & 3705481 & 672 \\
Edge Complex & 2005 & July 16 & 69,238 & 462952 & 3739169 & 813 \\
\hline
\end{tabular}

Among the 13 selected sites, years of fire occurrence ranged from 1980 to 2005 (33-8 years TSF, respectively; fig. 1). Ignition dates, area burned, and spatial coordinates for each fire are shown in table 1. We obtained geospatial polygons of fire perimeters from the Monitoring Trends in Burn Severity database (http://www.mtbs.gov) prior to field sampling. When existing perimeters were not available (for about one-half of the 13 fires), we calculated the difference in Normalized Burn Ratio (dNBR) from Landsat 5 Thematic Mapper satellite images recorded immediately pre- and post-fire (Key and Benson, 2005) and used those outputs to guide our transect placement for burned and unburned sites (fig. 2). Once the fire perimeters were established, we generated random points within each burned area using the "create random points" tool in ArcGIS ${ }^{\mathrm{TM}}$ software, version 9.3. 


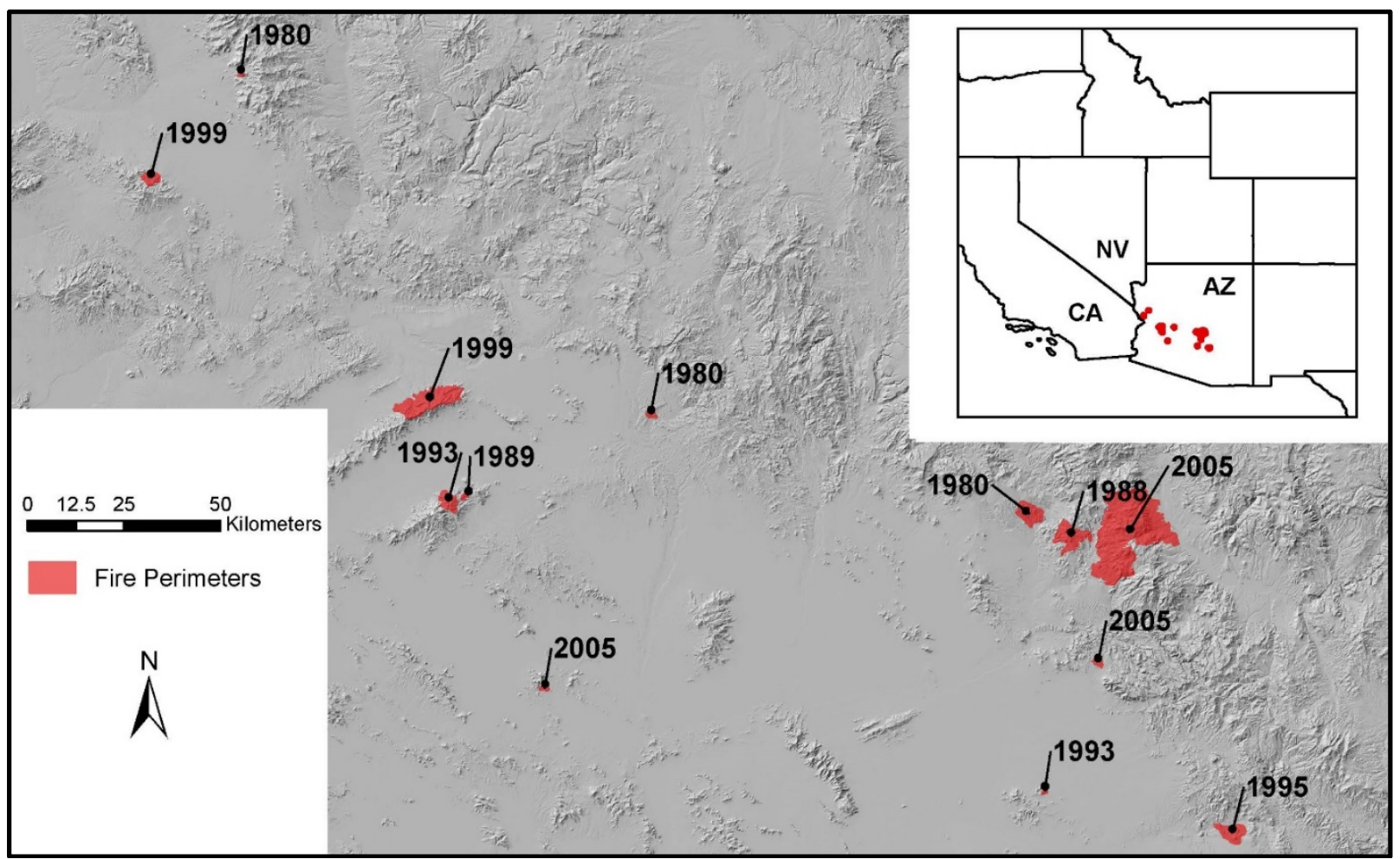

Figure 1. Perimeters of fires sampled in the Sonoran Desert ecoregion of central Arizona, 2013. Perennial vegetation was sampled at each burned area between March and November 2013.

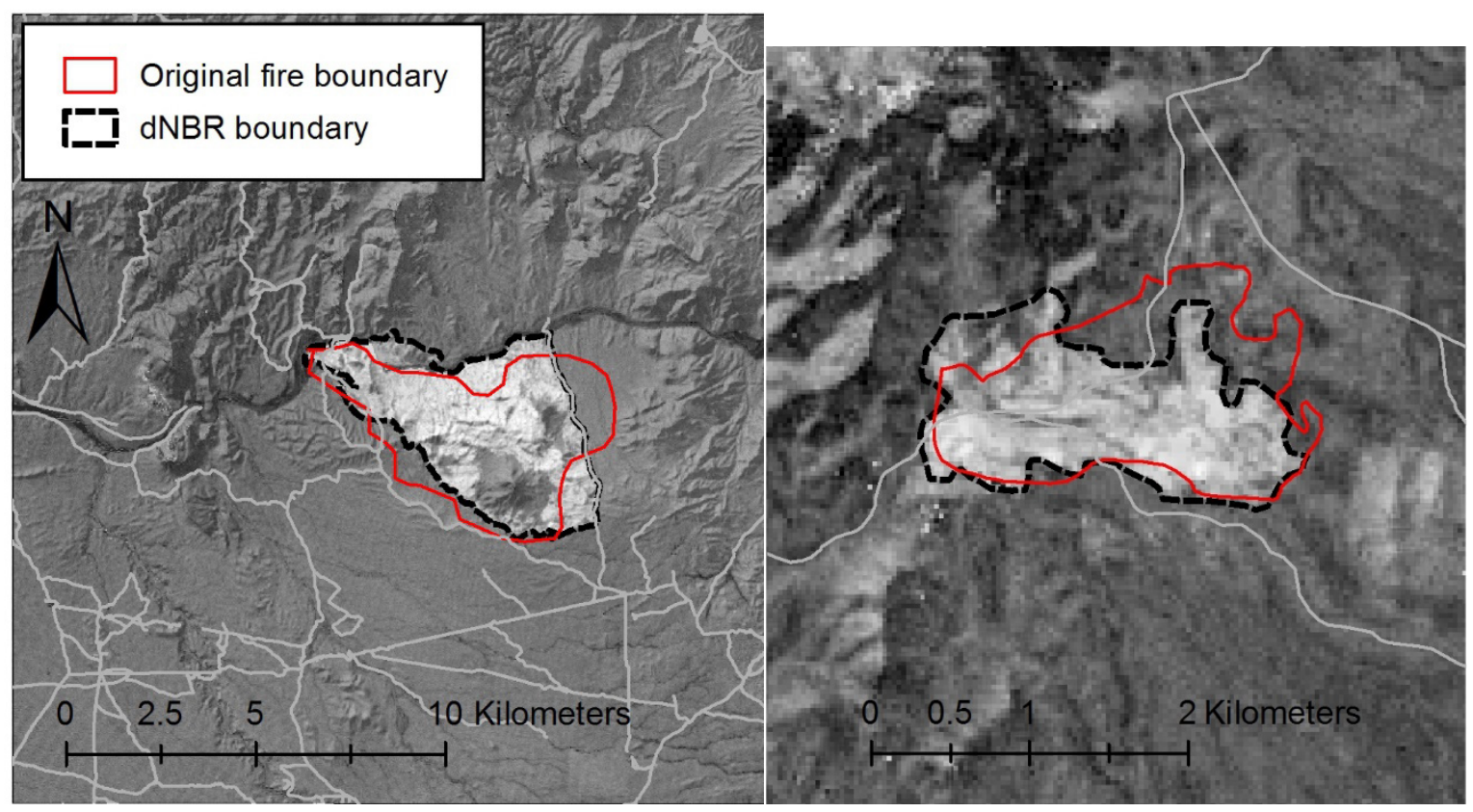

Figure 2. Examples of fire boundary development from remote sensing of the White Canyon fire (1995; left image) and the Nuke fire (2005; right image). The figures illustrate the relative positions of boundaries from the original Federal fire database and the dNBR - derived boundaries from Landsat. 


\section{Vegetation Sampling}

\section{Perennial Plant Species}

At each random transect point, we measured perennial vegetation cover, height, and density on a 50-m transect line whose azimuth was randomly selected. Vegetation cover was measured using the line-intercept technique, in which the lengths of all perennial plants intersecting the transect line, identified to the species level, were recorded. The height of each individual that intersected the transect line also was measured at its tallest point on or off the line-intercept. Plant density was measured on each transect by counting each individual perennial plant rooted inside $252-\mathrm{m} \times 1$-m quadrats centered at equal intervals along the 50-m transect line. Overall plant density for each transect was calculated as the sum of perennial plants per $100-\mathrm{m}^{2}$ belt transect. We sampled from 12 to 24 transects at each study area (depending on the size of the burned area), evenly divided between burned and unburned control areas, with more transects in the larger burned areas. Field sampling was conducted between March and November 2013.

\section{Invasive Plant Species}

Within each of the $252-\mathrm{m} \times 1$-m quadrats used to quantify perennial plant density, we documented presence or absence of invasive annual plant species to acquire frequencies of these plant species across the study areas. The abundance of one invasive perennial, buffelgrass (Cenchrus ciliaris), was recorded following the above methods for perennial species.

\section{Data Analysis}

\section{Environmental Variables}

We derived a set of environmental variables for analysis that represent the steep topographic and climatic gradients of our study region and that we hypothesized would serve as environmental filters affecting post-fire vegetation recovery (see table 2 for definitions). Elevation, slope, and aspect were based on a 30-m Digital Elevation Model (DEM) obtained from the National Elevation Dataset (http://ned.usgs.gov/) and were calculated using standard functions in $\operatorname{ArcGIS}^{\mathrm{TM}}$ version 9.3. Precipitation variables were based on the Parameter-elevation Relationships on Independent Slopes Model (PRISM) climate model (Daly and others, 2008; http://prism.oregonstate.edu).

Table 2. Environmental variables extracted at each transect location and included in analyses of the effects of fire on Sonoran Desert perennial vegetation.

[DEM, Digital Elevation Model; km, kilometer; m, meter; mm, millimeter; ${ }^{\circ}$, degrees; PRISM; Parameter-elevation Relationships on Independent Slopes Model]

\begin{tabular}{lll}
\multicolumn{1}{c}{$\begin{array}{c}\text { Variable } \\
\text { (units) }\end{array}$} & \multicolumn{1}{c}{ Code } & Source \\
\hline Elevation $(\mathrm{m})$ & Elevation & 30 -m DEM \\
Slope $\left(^{\circ}\right)$ & Slope & 30 -m DEM \\
Aspect northness & Asp.N & Cos $($ Aspect $\times \pi / 180)$, calculated from 30-m DEM \\
Annual precipitation $(\mathrm{mm})$ & Ann.Prcp & PRISM $^{1} 800 \mathrm{~m}$ interpolated climatic normal, 1981-2010 \\
Post-fire precipitation $(\mathrm{mm})$ & PF.Prcp & PRISM $^{1} 4 \mathrm{~km}$ interpolated historical climate grids. Total precipitation \\
& & received from January to December of first year following fire. \\
\hline
\end{tabular}

\footnotetext{
${ }^{1}$ Daly and others (2008), available at http://prism.oregonstate.edu.
} 


\section{Species and Growth-Form Response to Fire}

We tested whether fire altered the composition of species or growth-forms and whether such changes could be primarily attributed to TSF (fire-interval hypothesis) or abiotic conditions (environmental-filter hypothesis) using distance-based permutational Multivariate Analysis of Variance (perMANOVA; Anderson, 2001). In separate analyses, we partitioned the variability in perennial species composition or composition of perennial growth forms (trees, shrubs, subshrubs, forbs, grasses, and cacti) into components explained by burn treatment (burned or unburned), environmental variables (table 2), and TSF. These models partition the multivariate variability of response variables into separate additive components explained by each explanatory variable, and can involve interactions between terms. TSF was represented as a burn treatment $\times$ decade interaction, where burned and unburned transects from each fire were grouped according to the decade in which the fire occurred (2000s, 1990s, and 1980s). Models also included two-way interactions between burn treatment and environmental variables, but not interactions between environmental variables alone. Additionally, to determine whether there were persistent but non-directional changes in species or growth form composition, we computed separate perMANOVA models for fires in each decade (2000s, 1990s, and 1980s) with burn treatment as the sole predictor. Model significance was assessed by pseudo- $F$ ratios and permuted $P$ values (10,000 permutations). All tests were performed using the Bray-Curtis distance measure and the "vegan" package in R version 3.0.3 (Oksanen and others, 2013). Species that occurred on fewer than five transects were excluded prior to analysis.

To further evaluate whether differences in species composition between burned and unburned areas exhibited a directional response with increasing TSF, as expected under the fire-interval hypothesis, we conducted a Principal Response Curve (PRC) analysis on the dataset. This multivariate technique is analogous to the constrained ordination method Redundancy Analysis (RDA), but uses a single axis to express the rate of compositional change through time with respect to a reference condition (van den Brink and ter Braak, 1998, 1999). In PRC diagrams, this reference condition (here represented by unburned reference transects) is fixed at zero and indicated by a horizontal line, whereas separate lines show departure from the reference condition for each treatment (burned transects) as a function of time. Species scores along this axis can be calculated to reflect the influence of particular species on the overall community response. In other words, the species scores show the change in abundance of each particular species in the treatments relative to the control. To represent time in this analysis, we coded TSF as a factor with five levels: 10, 15, 20, 25, and 30 years post-fire. As with ordinary RDA, the significance of both treatment (burn) and time (TSF) terms in PRC models can be evaluated by permutations of the raw data. Separate PRC models for overall species composition and for composition of growth forms were fit using the "prc" function in the R version 3.0.3 package "vegan" (Oksanen and others, 2013). 
Because growth forms often show disparate responses to fire (for example, Keeley and others, 2006; Shryock and others, 2014), we modeled transect-level percentage cover of each growth form against environmental variables and TSF using Linear Mixed-Effects models (LME) ranked by biascorrected Akaike's Information Criterion (AICc). Fire location was treated as a random effect in all models, whereas burn treatment (burned or unburned) and the set of environmental variables (excluding post-fire precipitation; table 2) were treated as fixed effects. As in the perMANOVA models, we expressed TSF as a burn treatment $\times$ decade interaction and included two-way interactions between burn treatment and environmental variables. Candidate model sets were calculated using all combinations of the selected explanatory variables and ranked according to $\triangle \mathrm{AICc}$ values and model weights ( $w_{i}$; Anderson, 2008). Prior to identifying a candidate set of best-supported models, we removed overly complex models when a nested model (that is, containing a subset of the parameters) had a low AICc (Richards, 2008; Grueber and others, 2011). We then retained models with $\triangle \mathrm{AICc}$ of less than 4 and calculated the model weights for this set of best-supported models. We also calculated goodness-offit measures for the best-supported models relating to each growth form following the technique proposed in Nakagawa and Schielzeth (2013) including: $R_{m}^{2}$, or the variability explained by fixed-effect terms, and $R_{c}^{2}$, the variability explained by the full model including random effects. To visualize the separate influences of fixed-effect terms in the candidate model set $(\triangle \mathrm{AICc}<4)$ for each growth form, we calculated variable effect plots (Fox, 2003) with 95-percent confidence intervals surrounding modelaveraged predictions for each parameter in the candidate model set. In these displays, the explanatory variable of interest is varied across the range of its observed values while other terms are held at their median value. However, we chose not to display effect plots for interaction terms when the respective main effects were better supported (that is, higher Akaike weight) and occurred more frequently in the candidate model set. Standardized model-averaged coefficients (parameter estimates) for all terms in the candidate model sets for each growth form are provided in appendix A, table A1. All calculations were performed using R (version 3.0.3) with the "lme4," "AICcmodavg," and "effects" packages (Fox, 2003; Mazerolle, 2013; Bates and others, 2014).

\section{Response of Vegetation Structure to Fire}

To investigate influences operating at the level of vegetation structure, we modeled changes in transect-level vegetation cover, height, and density using LME models with fire identity treated as a random effect and the set of environmental variables (excluding post-fire precipitation; table 2), along with TSF (burn treatment $\times$ decade interaction), treated as fixed effects. In the same manner as described above (Species and Growth-Form Response to Fire), candidate model sets were identified, which included models with $\triangle \mathrm{AICc}$ of less than 4 (after removing overlay complex models through the nesting criterion), and goodness-of-fit values $\left(R_{m}^{2}\right.$ and $R_{c}^{2}$; Nakagawa and Schielzeth, 2013) were calculated for each of the candidate models, along with variable affect plots (Fox, 2003) for the modelaveraged parameters. Two-way interactions between burn treatment and environmental variables were included among the possible models, as above (Species and Growth-Form Response to Fire). Vegetation height and density measures were square root transformed prior to analysis to meet model assumptions. Standardized model-averaged coefficients for all terms in the candidate model sets are shown in appendix A, table A2. 


\section{Landscape Scale Vegetation Recovery}

We calculated burned/unburned ratios for average vegetation cover, height, and density as a means of expressing the level of vegetation recovery - or, conversely, departure from undisturbed conditions - for each fire $(n=13)$. These ratios were derived by averaging values for each vegetation attribute across burned and unburned reference transects for each fire, and then dividing the burned estimates by the unburned estimates. The importance of TSF on landscape-scale recovery patterns (representing the fire-interval hypothesis) was first evaluated by fitting linear regression models with fire year as predictor of each burned/unburned ratio. We then evaluated a set of candidate models including all combinations $(n=16)$ of TSF and three other environmental variables (representing environmental filters) that were averaged across transects for each fire: elevation, annual precipitation, and post-fire precipitation (table 2). Interaction terms were not included in these models to conserve degrees of freedom. Models were ranked according to $\triangle \mathrm{AICc}$, and adjusted $R^{2}$ values for the bestranked models are reported.

\section{Wildfire Effects on Sonoran Desert Tortoise Food and Cover Species}

A primary goal of this research is to identify how changes in desert vegetation wrought by fires affect desert tortoise habitat. To accomplish this goal within the financial resources and time that were available, we related how fire-driven changes in the vegetation documented in this study pertained to food or cover species identified in published accounts as relevant to desert tortoises. To assess the influence of vegetation changes on food species, we consulted the most comprehensive syntheses of desert tortoise food plants to date (Van Devender and others, 2002; Esque and others, 2014). Because a comparable synthesis does not exist for Sonoran Desert plants that are used as cover by desert tortoises, we developed a list of potential cover plants based on our experience working with desert tortoises over the past 30 years. We evaluated plant species responses to fire and environmental conditions through time for their value as food and cover plants (appendix B). Thus, our analyses of changes in food plants is a quantitative analysis based on the literature, whereas our analysis of cover plants primarily is based on expert opinion. We ranked cover species on a scale from 0 to 3 (3 being of highest importance for cover).

We identified indicator species that distinguished burned and unburned areas within each TSF category (1980s, 1990s, and 2000s fires) using Indicator Species Analysis (ISA; Dufrêne and Legendre, 1997). This technique is based on the relative frequency and abundance of species and shows their faithfulness and exclusivity to particular treatment groups (in this case, burn status). We conducted ISA hierarchically with 5,000 permutations and burn status as the treatment factor, first by overall burned/unburned status and then within each TSF category. Species were considered indicators of either treatment group at a significance level of $P$ less than 0.05 . We then identified which species among the significant indicators were tortoise food or cover species. 
The distributions of perennial species in relation to burn status (burned/unburned) and TSF (833 years post-fire) were further assessed with an Outlying Mean Index ordination (OMI; Dolédec and others, 2000) to analyze how food and cover plants varied in relation to unburned and burned areas. This multivariate technique measures the breadth of species distributions in relation to constraining environmental characteristics (in this case, burn status and TSF), and determines which species are significantly restricted in their abundance (compared to a hypothetical ubiquitous species with a distribution that is unaffected by the environmental constraints). In biological terms, this means that species with a high score on an OMI axis are exhibiting a strong response to the environmental variables representing that axis, whereas species located near the origin are exhibiting a weak response to these variables (that is, generalist species). Significance levels are determined through permutation and assessed at $P$ less than 0.05 .

\section{Results}

\section{Species and Growth-Form Response to Fire}

We identified 127 perennial plant taxa, with 115 species on unburned sites and 111 on burned sites (appendix C). Seven species were present in unburned areas and were absent in burned areas: Cercocarpus montanus; Ericameria linearifolia; Acamptopappus sphaerocephalus; Elymus elymoides; Ziziphus obtusifolia; Xylorhiza tortifolia; and Penstemmon subulatus. There were 6 species that were present in burned areas but were absent in unburned areas: Calochortus sp.; Nolina microcarpa; Parkinsonia florida; Baileya multiradiata, Hymenoclea salsola, and Pellaea truncata. There were 20 species that showed significant differences between burned and unburned sites when averaged across time, with 9 species that had significantly greater cover on unburned sites, and 11 species with significantly greater cover on burned sites (table 3 ). 
Table 3. Percentage relative cover by plant species averaged across 13 fires with a range in Time-Since-Fire (8-33 years) and spanning the Arizona Upland subdivision of the Sonoran Desert, Arizona.

[Bold values highlight whether unburned or burned sites had greater average cover. F-values are from one-way Analysis of Variance (ANOVA) with burn treatment (burned, unburned) and transect-level cover for each species. SE, standard error]

\begin{tabular}{|c|c|c|c|c|c|c|}
\hline \multirow{2}{*}{ Species } & \multirow{2}{*}{$\begin{array}{l}\text { Growth } \\
\text { form }\end{array}$} & \multicolumn{2}{|c|}{ Unburned } & \multicolumn{2}{|c|}{ Burned } & \multirow{2}{*}{ F-value } \\
\hline & & Cover & SE & Cover & SE & \\
\hline Parkinsonia microphylla & Tree & 4.715 & 0.689 & 2.603 & 0.459 & ${ }^{1} 6.59$ \\
\hline Eriogonum fasciculatum & Shrub & 4.103 & 0.794 & 1.424 & 0.422 & ${ }^{2} 9.06$ \\
\hline Ambrosia deltoidea & Shrub & 2.110 & 0.573 & 0.701 & 0.220 & ${ }^{1} 5.39$ \\
\hline Encelia farinosa & Shrub & 1.940 & 0.483 & 3.402 & 0.656 & ${ }^{3} 3.18$ \\
\hline Larrea tridentata & Shrub & 1.847 & 0.454 & 0.535 & 0.156 & ${ }^{2} 7.68$ \\
\hline Cylindropuntia acanthocarpa & Cactus & 1.043 & 0.228 & 0.450 & 0.109 & ${ }^{1} 5.61$ \\
\hline Pleuraphis rigida & Grass & 0.830 & 0.201 & 1.960 & 0.554 & ${ }^{3} 3.58$ \\
\hline Yucca baccata & Shrub & 0.548 & 0.196 & 0.087 & 0.066 & ${ }^{1} 5.08$ \\
\hline Ericameria laricifolia & Shrub & 0.516 & 0.244 & 0.055 & 0.037 & ${ }^{1} 3.60$ \\
\hline \multirow[t]{2}{*}{ Fouquieria splendens } & Shrub & 0.336 & 0.084 & 0.087 & 0.035 & ${ }^{2} 7.64$ \\
\hline & Grass & 0.290 & 0.087 & 0.764 & 0.255 & ${ }^{3} 2.99$ \\
\hline Muhlenbergia porteri & Grass & 0.251 & 0.118 & 0.043 & 0.024 & ${ }^{3} 3.07$ \\
\hline Sphaeralcea ambigua & Forb & 0.233 & 0.067 & 0.507 & 0.134 & ${ }^{3} 3.28$ \\
\hline Lotus rigidus & Forb & 0.084 & 0.038 & $\mathbf{0 . 3 0 7}$ & 0.112 & ${ }^{3} 3.45$ \\
\hline Stephanomeria sp. & Subshrub & 0.072 & 0.023 & 0.177 & 0.046 & ${ }^{1} 4.09$ \\
\hline Adenophyllum porophylloides & Subshrub & 0.057 & 0.022 & 0.428 & 0.127 & ${ }^{2} 7.97$ \\
\hline Bebbia juncea & Shrub & 0.024 & 0.016 & 0.141 & 0.058 & ${ }^{1} 3.67$ \\
\hline Lycium berlandieri & Shrub & 0.008 & 0.008 & 0.118 & 0.053 & ${ }^{1} 3.99$ \\
\hline Senna covesii & Forb & 0.003 & 0.003 & 0.052 & 0.025 & ${ }^{3} 3.61$ \\
\hline Dichelostemma capitatum & Forb & 0.002 & 0.001 & 0.013 & 0.006 & ${ }^{3} 3.37$ \\
\hline
\end{tabular}

${ }^{1} P<0.05$.

${ }^{2} P<0.01$.

${ }^{3} P<0.1$. 
Species composition differed significantly between burned and unburned areas in the perMANOVA model, but the interaction between burn treatment (burned or unburned) and time (decade) was not statistically significant (table 4). However, within decades, species composition differed significantly between burned and unburned areas for the recent fires from the 2000s and 1990s, but not for 1980s fires. Comparison of patterns among decades suggests persistent but non-directional shifts in species composition for at least the first 2 decades following a fire. Annual precipitation explained the greatest amount of variability in species composition, whereas elevation and aspect (northness) explained the second and third most variability, respectively (table 4). Post-fire precipitation also explained a smaller but significant amount of variability in species composition. Of the interaction terms, only burn $\times$ elevation explained a significant amount of variability, suggesting that elevation mediates the effects of fire on species composition.

Table 4. Influence of burn treatment, topography, and climate on post-fire composition of species and growth forms in the Sonoran Desert based on PerMANOVA tests.

[PF.Prcp denotes post-fire precipitation; Ann.Prcp denotes annual precipitation; $p s e u d o-F$ refers to PerMANOVA test statistics, which are sum-of-squares ratios as in classical ANOVA]

\begin{tabular}{|c|c|c|c|c|}
\hline & \multicolumn{2}{|c|}{ Species composition } & \multicolumn{2}{|c|}{ Growth forms } \\
\hline & Terms & pseudo-F & Terms & pseudo-F \\
\hline $\begin{array}{l}\text { 2000s } \\
1990 s \\
1980 s\end{array}$ & $\begin{array}{l}\text { Burn } \\
\text { Elevation } \\
\text { Slope } \\
\text { Northness } \\
\text { Ann.Prcp } \\
\text { PF.Prcp } \\
\text { Burn } \times \text { Decade } \\
\text { Burn } \times \text { Elevation } \\
\text { Burn } \times \text { Ann.Prcp } \\
\text { Burn } \times \text { Slope } \\
\text { Burn } \\
\text { Burn } \\
\text { Burn }\end{array}$ & $\begin{array}{r}4.75 \\
{ }^{1} 13.45 \\
{ }^{2} 2.71 \\
{ }^{1} 7.87 \\
{ }^{1} 20.11 \\
{ }^{1} 3.13 \\
1.38 \\
{ }^{3} 2.12 \\
1.48 \\
1.12 \\
{ }^{3} 2.41 \\
{ }^{3} 2.501 \\
1.285\end{array}$ & $\begin{array}{l}\text { Burn } \\
\text { Elevation } \\
\text { Slope } \\
\text { Northness } \\
\text { Ann.Prcp } \\
\text { PF.Prcp } \\
\text { Burn } \times \text { Decade } \\
\text { Burn } \times \text { Elevation } \\
\text { Burn } \times \text { Ann.Prcp } \\
\text { Burn } \times \text { Slope } \\
\text { Burn } \\
\text { Burn } \\
\text { Burn }\end{array}$ & $\begin{array}{c}11.20 \\
{ }^{1} 23.68 \\
{ }^{1} 3.22 \\
24.4 \\
{ }^{2} 17.73 \\
{ }^{1} 173.35 \\
{ }^{3} 2.35 \\
0.83 \\
2.10 \\
{ }^{3} 2.51 \\
0.34 \\
2.077 \\
24.813 \\
{ }^{3} 3.038\end{array}$ \\
\hline
\end{tabular}

${ }^{1} P<0.001$.

${ }^{2} P<0.01$.

${ }^{3} P<0.05$. 
Tests for differences in growth form response to fire through time and abiotic variables followed a pattern similar to patterns for overall species composition. However, burn treatment explained a larger amount of variability in growth form composition than in species composition (table 4). Elevation and annual precipitation explained the most variability in growth form composition, while aspect (northness) and slope also had a significant influence. Of the interaction terms, only burn $\times$ annual precipitation exerted a significant influence, suggesting a mediating effect of annual precipitation on the response of growth forms to fire. As with overall species composition, persistent but non-directional shifts in growth from composition were suggested - differences between burned and unburned transects from 1990s and 1980s fires were significant, but no significant burn $\times$ decade interaction was detected.

Principal response curves (PRC) provided further evidence that fire changed the composition of plant species and growth forms; however, burned areas did not become either more or less similar to unburned control areas through time (fig. 3a and $\mathrm{b}$ ). The PRC model for species composition included a significant effect of burn treatment $(F=4.48, P<0.001)$ but not TSF $(F=1.04, P=0.388)$. Similarly, growth form composition was significantly different between burned areas and unburned reference sites $(F=13.08, P<0.001)$, but no directional trend occurred through time (TSF: $F=0.55, P=0.876)$. Based on the species scores (fig. 3a), Parkinsonia microphylla, Ambrosia deltoidea, and Eriogonum fasciculatum were most reduced in burned areas relative to unburned reference sites. In contrast, Encelia farinosa and Pleuraphis rigida had the largest increases in cover in burned areas. Overall, a large number of species $(n=8)$ had highly negative scores on the PRC axis $(<-0.5$, fig. $3 a)$, indicating lower relative abundance in burned areas than those species that had highly positive scores $(>0.5 ; n=5)$. Among growth forms, shrubs were by far the most reduced in burned areas relative to unburned reference sites, followed by trees and cacti. In contrast, forbs, subshrubs, and grasses all showed greater relative abundance in burned areas (fig. 3b). PRC scores for all species are provided in appendix C, table $\mathrm{C} 1$.


Figure 3. Principal response curves showing the rate of change relative to unburned areas as a function of TimeSince-Fire (TSF) in burned (a) species composition and (b) growth form composition. Individual species and growth form scores are shown on the right axis (high scores indicate a strong response). Plant codes: ENFA, Encelia farinosa; PLRI, Pleuraphis rigida; CAER, Calliandra eriophylla; ARPU, Aristida purpurea; GUSA, Gutierrezia sarothrae; YUBA, Yucca baccata; ERLA, Ericameria laricifolia; CYAC, Cylindropuntia acanthocarpa; SICH, Simmondsia chinensis; LATR, Larrea tridentata; AMDE, Ambrosia deltoidea; PAMI, Parkinsonia microphylla; and ERFA, Eriogonum fasciculatum. 
LME models for individual growth forms suggest that environmental filters and, to a lesser extent, TSF (burn $\times$ decade interaction) influenced transect-level cover (table 5). The best-fitting models $\left(R^{2} m>0.40\right)$ were obtained for grass and shrub cover, whereas models for tree cover explained relatively little variability $\left(R^{2} m<0.10\right)$. Shrub cover increased with higher elevation and greater annual precipitation, but cover in burned areas was lowest relative to unburned reference sites where annual precipitation was high (fig. 4a). Forb cover was highest in burned areas of the recent fires (2000s), but did not differ between burned and unburned areas for older fires (fig. 4f). Increased forb cover in burned relative to unburned areas was most pronounced at higher elevations (fig. 4f). Cactus cover also was related to TSF; however, in contrast to forbs, cover was reduced in burned areas in the recent fires, but no differences were found in older decades (fig. 4c). Tree cover was reduced in burned relative to unburned areas, but did not show a strong response to either TSF or environmental conditions, though decreasing slightly with more northerly aspects (fig. 4d). Grass cover increased with elevation at a greater rate in burned areas relative to unburned areas, and increased with more northerly aspects (fig. 4e). Finally, subshrub cover increased with slope and aspect at a greater rate in burned than unburned areas (fig. 4b). Subshrub cover also increased with higher elevation and annual precipitation. 
Table 5. Candidate models ranked by bias-corrected Akaike's Information Criterion (AICc) showing the influence of fire, topography, and climate on perennial growth form cover.

$\left[\triangle \mathrm{AICc}\right.$ refers to the difference in bias-corrected Akaike's Information Criterion between models, $w_{i}$ refers to model weights calculated based on the models in the candidate set, $R_{m}^{2}$ refers to the marginal variability explained by fixed-effect terms alone, $R_{c}^{2}$ refers to the variability explained by the full model. LME, Linear Mixed-Effects models]

\begin{tabular}{|c|c|c|c|c|}
\hline \multirow{2}{*}{ LME models: growth forms } & \multicolumn{4}{|c|}{ Evaluation criteria } \\
\hline & $\triangle \mathrm{AICc}$ & $w_{i}$ & $R^{2} m$ & $R^{2}{ }_{c}$ \\
\hline \multicolumn{5}{|c|}{ Tree cover } \\
\hline Burn + Asp.N & 0.000 & 0.83 & 0.070 & 0.284 \\
\hline Burn & 3.180 & 0.17 & 0.038 & 0.231 \\
\hline Null (intercept only) & 9.364 & 0.00 & NA & 0.180 \\
\hline \multicolumn{5}{|c|}{ Shrub cover } \\
\hline Burn $\times$ Ann.Prcp + Burn $\times$ Asp. $N+$ Elevation & 0.000 & 0.25 & 0.404 & 0.447 \\
\hline Burn $\times$ Ann.Prcp + Elevation & 0.500 & 0.19 & 0.389 & 0.435 \\
\hline Burn $\times$ Asp. $N+$ Elevation + Ann.Prcp & 1.620 & 0.11 & 0.394 & 0.437 \\
\hline Burn $\times$ Ann.Prcp + Burn $\times$ Asp.N & 1.690 & 0.11 & 0.373 & 0.455 \\
\hline Burn $\times$ Elevation + Ann.P & 1.760 & 0.10 & 0.387 & 0.433 \\
\hline Burn + Elevation + Ann.P & 1.850 & 0.10 & 0.378 & 0.425 \\
\hline Burn $\times$ Ann.Prcp & 1.890 & 0.10 & 0.361 & 0.440 \\
\hline Burn + Ann.Prcp & 3.27 & 0.05 & 0.352 & 0.431 \\
\hline Null (intercept only) & 45.06 & 0.00 & NA & 0.309 \\
\hline \multicolumn{5}{|c|}{ Subshrub cover } \\
\hline Burn $\times$ Slope + Burn $\times$ Asp. $N+$ Ann.Prcp & 0.000 & 0.29 & 0.212 & 0.330 \\
\hline Burn $\times$ Slope + Asp. $N+$ Ann.Prcp & 0.540 & 0.22 & 0.200 & 0.320 \\
\hline Burn $\times$ Asp. $N+$ Elevation + Slope + Ann.Prcp & 0.900 & 0.18 & 0.240 & 0.332 \\
\hline Burn $\times$ Asp. $. N+$ Slope + Ann.Prcp & 1.550 & 0.13 & 0.203 & 0.313 \\
\hline Burn + Slope + Asp. $. N+$ Elevation + Ann.Prcp & 2.380 & 0.09 & 0.223 & 0.319 \\
\hline Burn + Slope + Asp. $. N+$ Ann.Prcp & 2.550 & 0.08 & 0.188 & 0.299 \\
\hline Null (intercept only) & 20.678 & 0.00 & NA & 0.102 \\
\hline \multicolumn{5}{|c|}{ Forb cover } \\
\hline Burn $\times$ Decade + Burn $\times$ Elevation + Asp..$N$ & 0.000 & 0.35 & 0.246 & 0.352 \\
\hline Burn $\times$ Decade + Burn $\times$ Elevation & 1.006 & 0.21 & 0.218 & 0.332 \\
\hline Burn $\times$ Decade + Burn $\times$ Asp. $N+$ Elevation & 1.641 & 0.15 & 0.243 & 0.337 \\
\hline Burn $\times$ Decade + Asp. $N+$ Elevation & 1.675 & 0.15 & 0.233 & 0.330 \\
\hline Burn $\times$ Decade + Elevation & 1.920 & 0.13 & 0.211 & 0.315 \\
\hline Null (intercept only) & 11.57 & 0.00 & NA & 0.170 \\
\hline \multicolumn{5}{|c|}{ Grass cover } \\
\hline Burn $\times$ Elevation + Asp. $N$ & 0.000 & 0.86 & 0.417 & 0.484 \\
\hline Burn $\times$ Elevation & 3.70 & 0.14 & 0.381 & 0.462 \\
\hline Null (intercept only) & 37.54 & 0.00 & NA & 0.261 \\
\hline \multicolumn{5}{|c|}{ Cactus cover } \\
\hline Burn $\times$ Decade + Slope + Ann.Prcp & 0.000 & 0.34 & 0.310 & 0.498 \\
\hline Burn $\times$ Decade + Ann.Prcp + Elevation & 1.074 & 0.20 & 0.337 & 0.499 \\
\hline Burn $\times$ Decade + Slope & 1.300 & 0.18 & 0.293 & 0.493 \\
\hline Burn $\times$ Decade + Ann.Prcp & 2.410 & 0.10 & 0.289 & 0.483 \\
\hline Burn $\times$ Decade + Elevation + Asp.. $\mathrm{N}$ & 3.370 & 0.06 & 0.280 & 0.487 \\
\hline Burn $\times$ Decade + Elevation & 3.380 & 0.06 & 0.255 & 0.479 \\
\hline Burn $\times$ Decade & 3.720 & 0.05 & 0.219 & 0.485 \\
\hline Null (intercept only) & 12.82 & 0.00 & NA & 0.329 \\
\hline
\end{tabular}


(a)
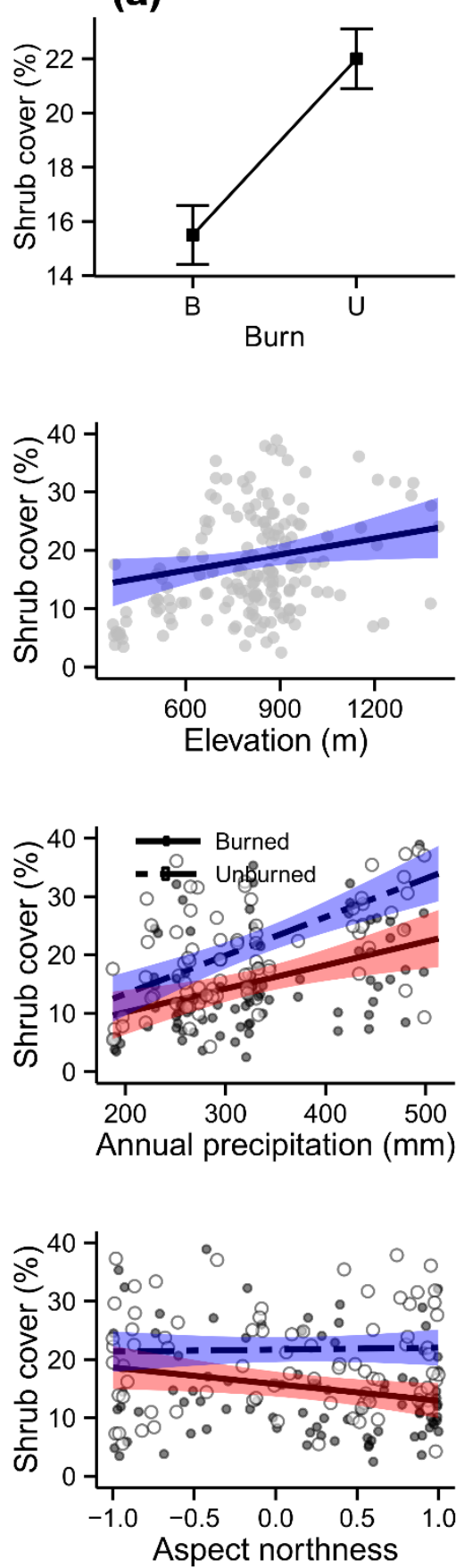

(b)
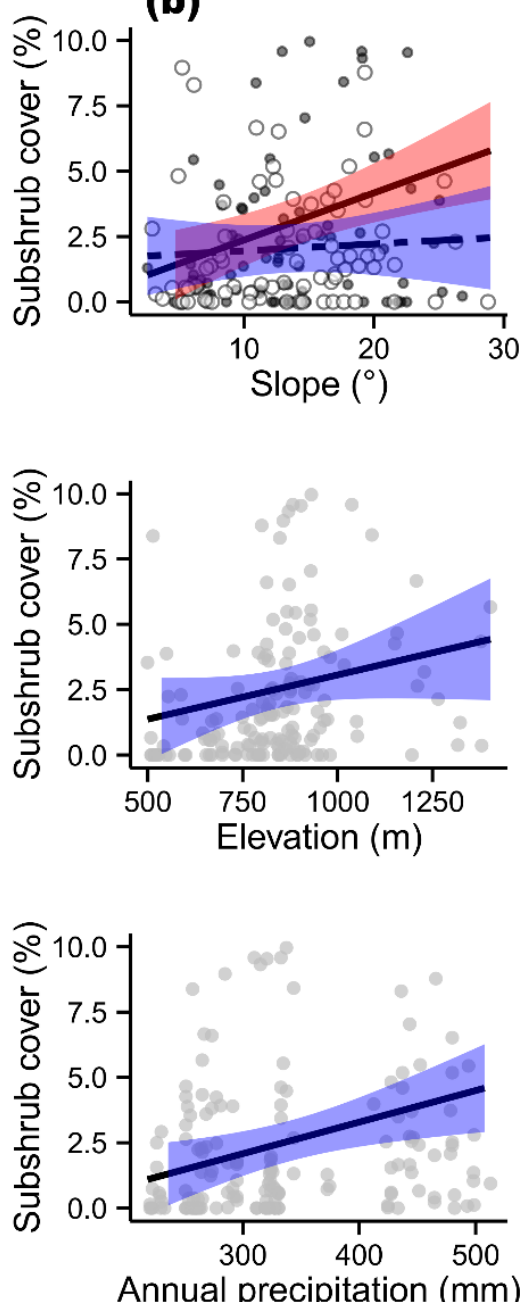

Annual precipitation ( $\mathrm{mm}$ )

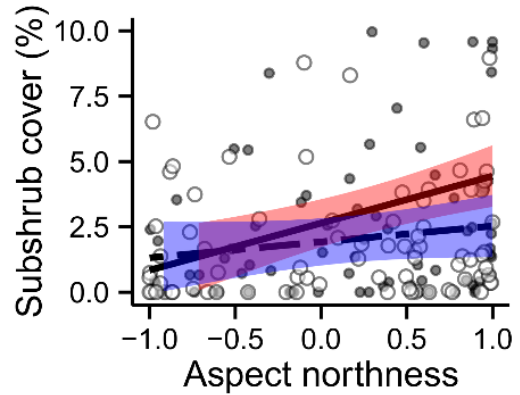

(c)
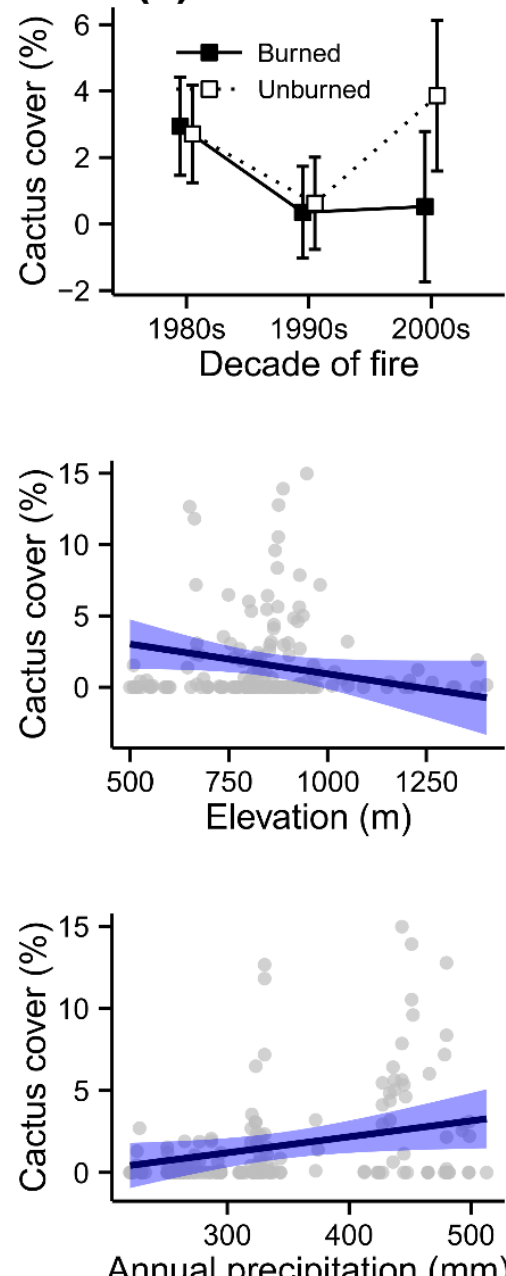

Annual precipitation ( $\mathrm{mm}$ )

Figure 4. Effect plot displays for modal-averaged parameters in candidate model sets predicting cover of individual growth forms with respect to fire, topography, climate, or Time-Since-Fire. Shaded bands indicate 95-percent confidence intervals for model predictions. Plots with separate predictions for burned and unburned areas (see plot explanations) indicate interaction terms. Growth form responses are organized by column: (a) shrub, (b) subshrub, (c) cactus, (d) tree, (e) grass, and (f) forb. 

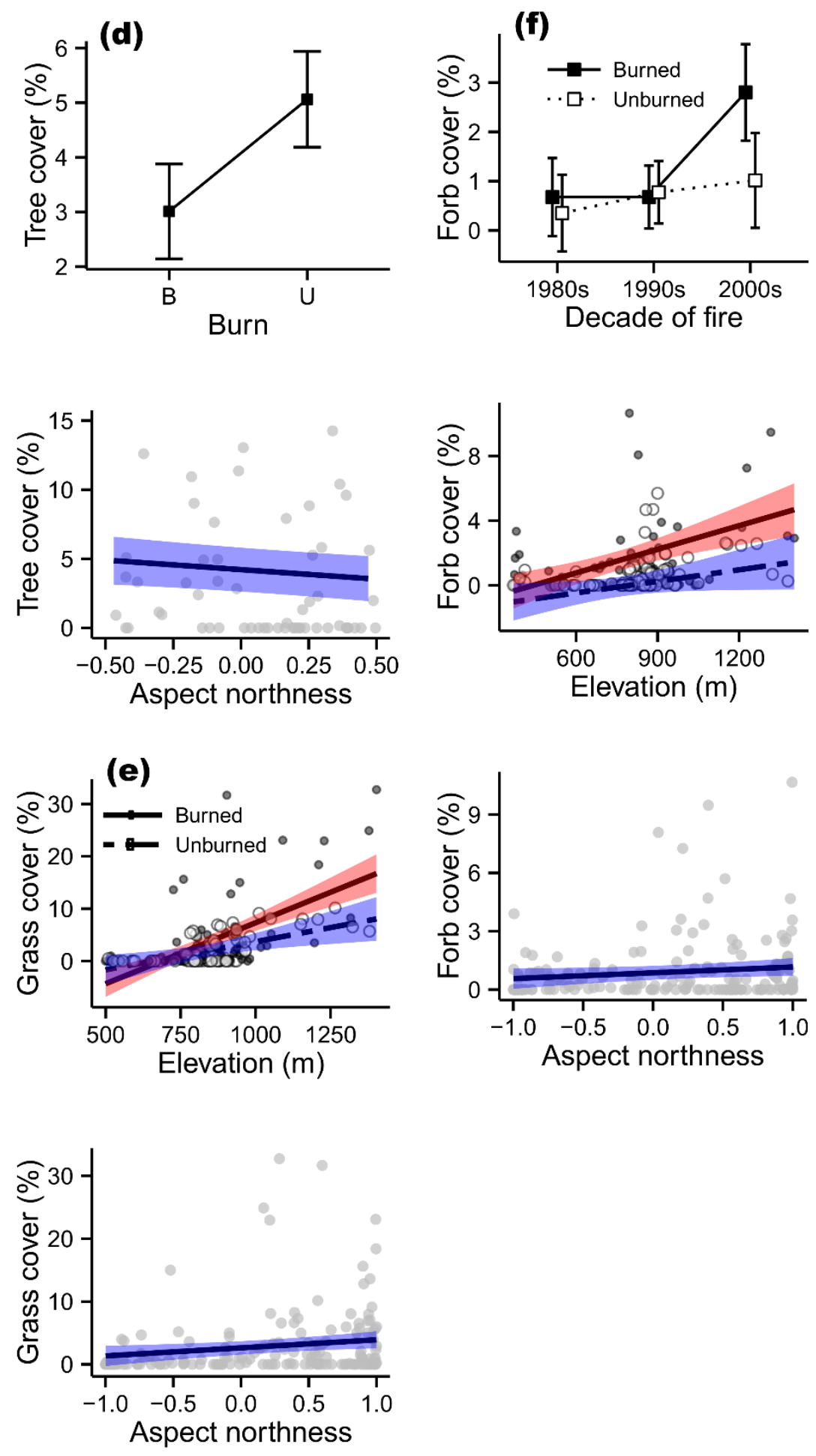

Figure 4.-Continued 


\section{Invasive Species}

Four invasive plant species were observed on transects including the annuals Bromus madritensis, Schismus spp., and Erodium cicutarium, and the perennial invasive Cenchrus ciliaris. Bromus and Schismus were both observed on transects at 8 of the 13 study areas. The frequency of observations was highly variable because these species are annual plants and the project was field surveyed during only 1 year. Furthermore, some of the study areas were visited in the autumn during a period when these species are present primarily as dormant seed. The frequencies of observation for Bromus were not significantly different between burned and unburned areas at $P$-values of 0.05 , or 0.1 (appendix D). Bromus was present in about one-half of all quadrats in both burned and unburned areas. There were significantly more frequent observations of Schismus in unburned areas than in burned areas, but this relationship was owing largely to a single fire (White Canyon). Erodium cicutarium was observed with slightly higher frequency in burned areas than in unburned areas, but the difference was not statistically significant. Cenchrus was observed only at the San Tan site and there was no significant difference between the burned and unburned habitat for this species (Unburned Mean Percent Cover $=0.185 \mathrm{~cm}, 0.17 \mathrm{SE}$; Burned Mean Percent Cover=0.01 cm, 0.01 SE; $F=0.97 ; P>0.10$ ).

\section{Response of Vegetation Structure to Fire}

Mean percentage vegetation cover was reduced overall in burned areas (27.21 \pm 1.47 percent) relative to unburned reference sites ( $33.05 \pm 1.48$ percent). Although no single candidate model for vegetation cover received overwhelming support from the analyses, based on Akaike weights $\left(w_{i}\right)$, the model with the lowest AICc value (that is, the highest likelihood) included burn treatment, elevation, slope, and average annual precipitation as explanatory variables $\left(R_{m}^{2}=0.523, R_{c}^{2}=0.629\right.$; table 6). Cover increased with increasing elevation, slope, and annual precipitation (fig. 5a). However, the burn treatment $\times$ decade interaction, reflecting TSF, was absent among the highest ranked models and first appeared in a model with $\triangle \mathrm{AICc}=4.72$, outside of the candidate model set.

In contrast to vegetation cover, vegetation density (plants $\left./ \mathrm{m}^{2}\right)$ was greater in burned $(3.00 \pm 0.22$ plants $\left./ \mathrm{m}^{2}\right)$ than in unburned reference sites $\left(2.35 \pm 0.18\right.$ plants $\left./ \mathrm{m}^{2}\right)$, and was strongly influenced by TSF, as the burn $\times$ decade interaction occurred in both the first and third-ranked models $(\triangle \mathrm{AICc}=0,0.67$, respectively). Burned areas in the first decade following fire showed larger differences in density relative to unburned areas (burned, $4.19 \pm 0.16$ plants $/ \mathrm{m}^{2}$; unburned, $2.78 \pm 0.16 \mathrm{plants} / \mathrm{m}^{2}$ ) than burned areas 2 decades (burned, $2.18 \pm 0.11$ plants $/ \mathrm{m}^{2}$; unburned: $1.59 \pm 0.11 \mathrm{plants} / \mathrm{m}^{2}$ ) and 3 decades (burned, $2.47 \pm 0.13$ plants $/ \mathrm{m}^{2}$; unburned, $2.35 \pm 0.13$ plants $/ \mathrm{m}^{2}$ ) following fire (fig. $5 \mathrm{~b}$ ). Burned areas in the first post-fire decade also showed the highest overall plant density. Based on the candidate model set, overall vegetation density also increased with elevation and along more northerly aspects (table 6). A burn $\times$ annual precipitation interaction in the second-ranked model indicated that vegetation density decreased with greater annual precipitation in burned areas, but increased with greater annual precipitation in unburned areas (fig. 5b). 
As with vegetation cover, average vegetation height was less in burned areas $(53.90 \pm 0.28 \mathrm{~cm})$ than in unburned reference sites $(75.35 \pm 0.28 \mathrm{~cm})$. Again, no single candidate model received overwhelming support. The highest-ranked model included burn treatment $\times$ slope interactions and burn treatment $\times$ annual precipitation, along with aspect northness $\left(R_{m}^{2}=0.260, R_{c}^{2}=0.522\right.$; table 6). Vegetation height remained relatively constant with increasing slope in burned areas, but decreased with increasing slope in unburned areas (fig. 6), such that the largest disparities in height between burned and unburned areas occurred on relatively flat surfaces. Vegetation height also increased with greater annual precipitation in burned areas, but decreased with greater annual precipitation in unburned areas, resulting in larger differences where annual precipitation was low (fig. 6). The burn $\times$ decade interaction occurred only in the third-ranked model $(\triangle \mathrm{AICc}=0.369)$, indicating a slight TSF influence — differences in vegetation height between burned and unburned areas were greater in the first decade following fire (burned, $34.95 \pm 0.54 \mathrm{~cm}$; unburned, $66.97 \pm 0.52 \mathrm{~cm}$ ) than in the second (burned, $59.10 \pm 0.34 \mathrm{~cm}$; unburned, $76.82 \pm 0.37 \mathrm{~cm}$ ) and third (burned, $61.98 \pm 0.43 \mathrm{~cm}$; unburned, $80.24 \pm 0.42 \mathrm{~cm}$ ) post-fire decades (fig. 6).

Table 6. Candidate model sets $(\triangle \mathrm{AIC}<4)$ showing the influence of fire, topography, and climate on vegetation cover, height, and density, respectively.

[ $\triangle \mathrm{AICc}$ refers to the difference in bias-corrected Akaike's Information Criterion between models, $w_{i}$ refers to model weights calculated based on the models in the candidate set, $R_{m}^{2}$ refers to the marginal variability explained by fixed-effect terms alone, and $R_{c}^{2}$ refers to the variability explained by both fixed and random effects in each model]

\begin{tabular}{|c|c|c|c|c|}
\hline \multirow{2}{*}{ LME models: vegetation attributes } & \multicolumn{4}{|c|}{ Evaluation criteria } \\
\hline & $\Delta \mathrm{AlCc}$ & $w_{i}$ & $R_{m}^{2}$ & $R_{c}^{2}$ \\
\hline \multicolumn{5}{|c|}{ Vegetation cover } \\
\hline Burn + Elevation + Slope + Ann.Prcp & 0.000 & 0.55 & 0.523 & 0.629 \\
\hline Burn + Elevation + Ann.Prcp & 0.376 & 0.45 & 0.524 & 0.599 \\
\hline Null (intercept only) & 44.960 & 0.00 & NA & 0.414 \\
\hline \multicolumn{5}{|c|}{ Vegetation height } \\
\hline Burn $\times$ Slope + Burn $\times$ Ann.Prcp + Asp.N & 0.000 & 0.22 & 0.260 & 0.522 \\
\hline Burn $\times$ Ann.Prcp + Burn $\times$ Slope & 0.347 & 0.19 & 0.247 & 0.513 \\
\hline Burn $\times$ Decade + Burn $\times$ Ann.Prcp + Elevation + Asp. $N$ & 0.369 & 0.18 & 0.348 & 0.509 \\
\hline Burn $\times$ Asp. $N+$ Burn $\times$ Ann.Prcp & 0.501 & 0.17 & 0.251 & 0.501 \\
\hline Burn $\times$ Ann.Prcp + Asp. $N$ & 1.090 & 0.13 & 0.242 & 0.494 \\
\hline Burn $\times$ Ann.Prcp & 1.334 & 0.11 & 0.230 & 0.487 \\
\hline Null (intercept only) & 55.570 & 0.00 & NA & 0.211 \\
\hline \multicolumn{5}{|c|}{ Vegetation density } \\
\hline Burn $\times$ Decade + Elevation + Asp.N & 0.000 & 0.34 & 0.405 & 0.537 \\
\hline Burn $\times$ Ann.Prcp + Elevation & 0.459 & 0.27 & 0.257 & 0.516 \\
\hline Burn $\times$ Decade + Elevation & 0.666 & 0.24 & 0.377 & 0.523 \\
\hline Burn + Elevation & 1.521 & 0.16 & 0.253 & 0.504 \\
\hline Null (intercept only) & 19.261 & 0.00 & NA & 0.384 \\
\hline
\end{tabular}





Figure 5. Effect plot displays of model-averaged parameters in candidate model sets for (a) vegetation percentage cover, and (b) vegetation density with respect to burn status, topography, climate, or Time-Since-Fire. Shaded bands indicate 95-percent confidence intervals for model predictions. Plots with separate predictions for burned and unburned areas (see plot explanations) indicate interaction terms. 

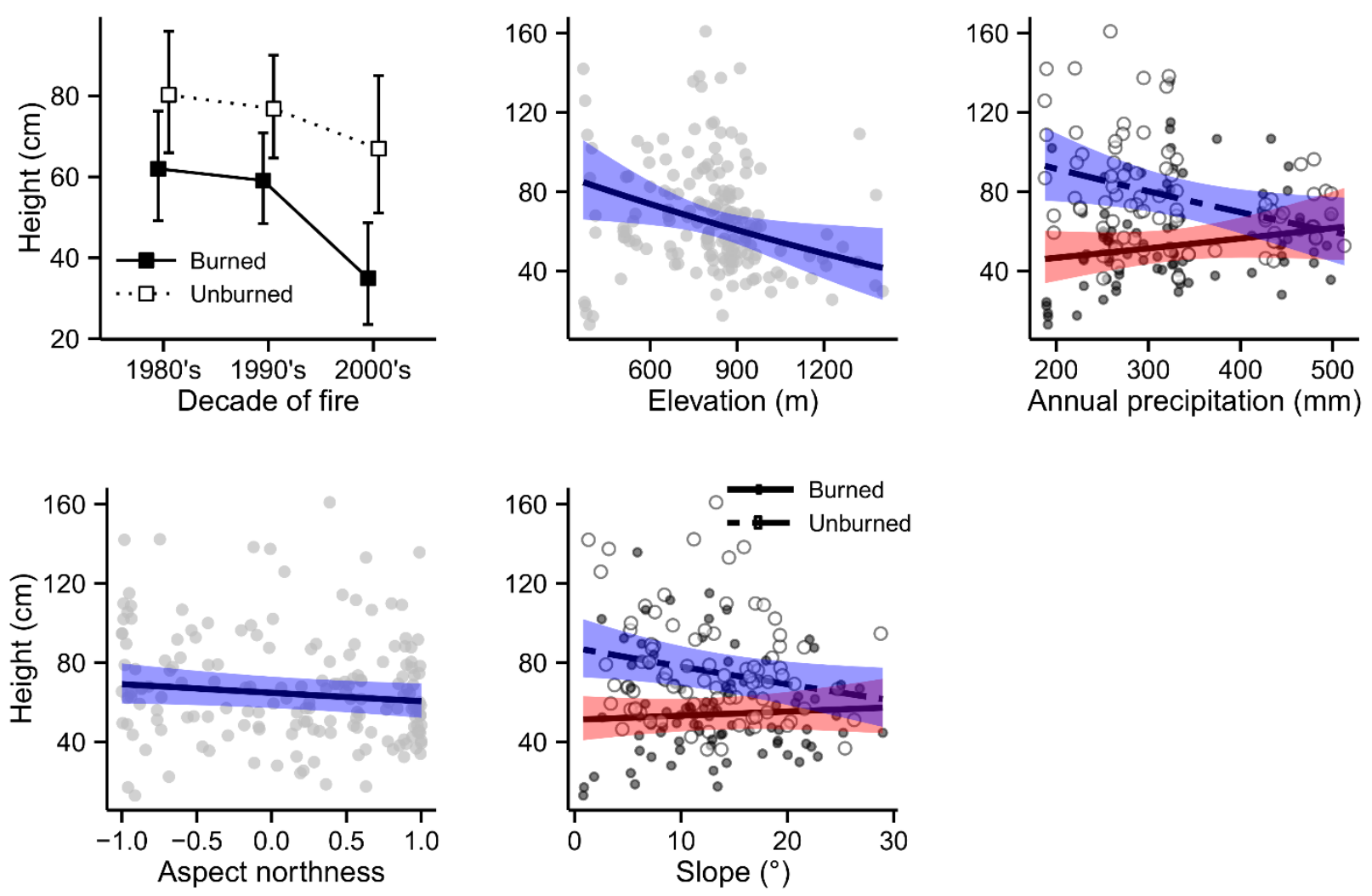

Figure 6. Effect plot displays of model-averaged parameters in candidate model sets for average vegetation height with respect to burn status, topography, climate, or time-since-fire. Shaded bands indicate 95-percent confidence intervals for model predictions. Plots with separate predictions for burned and unburned areas (see plot explanations) indicate interaction terms.

\section{Landscape Scale Vegetation Recovery}

Burned/unburned ratios for vegetation cover ranged from a low of 0.48 to a high of 1.07 (mean $=0.79$ ), whereas ratios ranged from 0.33 to 1.15 for vegetation height (mean=0.73) and from 0.66 to 2.22 for vegetation density (mean=1.37). Regressions including TSF as the sole predictor of vegetation recovery (burned/unburned ratio) indicated only weak relations (cover, $R^{2}=0.09$; height, $R^{2}=0.08$; density: $R^{2}=0.17$; fig. 7). In contrast, the highest-ranked models (lowest AICc value) included elevation, post-fire precipitation, and annual precipitation as predictors for burned/unburned ratios of vegetation cover, height, and density, respectively (table 7, fig. 7).

The ratio of burned/unburned cover increased with increasing elevation $\left(R^{2}=0.50\right.$; fig. 7a), and the ratio of burned/unburned height increased with greater post-fire precipitation $\left(R^{2}=0.72 ;\right.$ fig. $\left.7 \mathrm{~b}\right)$. In contrast, the ratio of burned/unburned density decreased with greater annual precipitation $\left(R^{2}=0.41\right.$; fig. 7c). 
Table 7. Linear regression models explaining the ratio of burned to unburned vegetation cover, height, and density, ranked by bias-corrected Akaike's Information Criterion (AICc).

[ $\triangle \mathrm{AICc}$ refers to the difference in bias-corrected Akaike's Information Criterion between models, $w_{i}$ refers to model weights calculated based on the models in the candidate sets. B/U, Burned $\div$ unburned; PF.PRCP, post-fire precipitation; Ann.PRCP, annual precipitation]

\begin{tabular}{|c|c|c|c|}
\hline Model & $\triangle \mathrm{AICc}$ & $w_{i}$ & $R^{2}{ }_{a d j}$ \\
\hline \multicolumn{4}{|c|}{$\mathrm{B} / \mathrm{U}$ Vegetation cover ratio } \\
\hline Elevation & 0.00 & 0.616 & 0.501 \\
\hline Elevation + PF.Prcp & 3.05 & 0.134 & 0.503 \\
\hline Elevation + Year & 4.29 & 0.072 & 0.450 \\
\hline Null (intercept only) & 7.88 & 0.010 & 0.000 \\
\hline \multicolumn{4}{|c|}{ B/U Vegetation height ratio } \\
\hline PF.Prcp & 0.00 & 0.571 & 0.720 \\
\hline PF.Prcp + Ann.Prcp & 2.14 & 0.196 & 0.740 \\
\hline PF.Prcp + Year & 3.58 & 0.095 & 0.710 \\
\hline Null (intercept only) & 14.23 & 0.000 & 0.000 \\
\hline \multicolumn{4}{|c|}{ B/U Vegetation density ratio } \\
\hline Ann.Prcp & 0.00 & 0.207 & 0.410 \\
\hline PF.Prcp & 0.16 & 0.191 & 0.401 \\
\hline Elevation + Ann.Prcp & 0.30 & 0.179 & 0.522 \\
\hline Null (intercept only) & 4.48 & 0.020 & 0.000 \\
\hline
\end{tabular}





Figure 7. Linear regression models comparing the influence of Time-Since-Fire (TSF, shown as year of fire) and environmental variables on the ratios of burned-to- unburned vegetation cover (a), height (b), and density (c). Right panels show the best-ranked $(\triangle \mathrm{AICC}=0)$ models. Shaded bands indicate 95-percent confidence intervals surrounding model predictions. Horizontal dashed line indicated a burned / unburned ratio of 1 (that is, no difference). 


\section{Long-Term Influences of Fire on Desert Tortoise Habitat}

The most direct long-term effects of wildfire on Sonoran Desert Tortoise habitat involve changes in the availability of food, thermal refugia, and protection from predation. The most comprehensive synthesis of food resources used by the Sonoran Desert Tortoise documented 90 species of food plants from the existing literature at that time (Van Devender and others, 2002). Little information regarding food species has been added to the literature since that publication (Esque and others, 2014), and a quantitative assessment of desert tortoise cover has not been completed for the Sonoran Desert Tortoise.

Among the 127 plant taxa observed during our vegetation surveys of unburned and burned areas, 26 plant taxa were previously identified as desert tortoise food plants including 1 cactus, 6 perennial forbs, 4 subshrubs, 11 shrubs, 3 grasses, and 1 tree (Van Devender and others, 2002, table 8). The absence of a species on the food or cover lists used in this report does not preclude those species from being used by tortoises. Additional studies on these topics likely would identify many more species.

When averaged across all our study areas, Adenophyllum porophylloides, Stephanomeria pauciflora, and Lotus rigidus were prominent indicator species for burned sites and are known as food species for the Sonoran Desert Tortoise, whereas Eriogonum fasciculatum was the only food taxon identified as an important indicator of unburned habitat in the overall analysis (table 9). By contrast Larrea tridentata and Yucca baccata were both identified as indicators of unburned habitat and both provide suitable thermal cover for tortoises (Nussear, 2004; Snyder, 2014; Drake and others,). Although the study areas representing the different decades in table 9 occur in different places, there was a pattern toward finding more food plant species that were indicator species of burned areas, and in contrast, more cover plants indicating unburned areas (table 8). This pattern is supported by aggregating percentage cover values of tortoise food and cover species across fires: The burned/unburned percentage cover ratio for food species as a whole was 2.713 , indicating greater overall abundance in burned sites, whereas the same ratio for cover species was 0.871 , indicating reduced cover within burns. However, we did not detect a temporal trend in burned/unburned ratios for either cover species or food species (fig. 8). Hence, environmental characteristics of burn areas likely are more influential than TSF in determining the responses of these species to fire- a conclusion supported by our analysis of growth forms. 
Table 8. Tortoise food species (derived from Van Devender and others, 2002) observed on burned and unburned plots at 13 study areas in the Arizona Upland Subdivision of the Sonoran Desert, Arizona.

[For each species, cover was averaged across burned and unburned transects, and then the burned average was divided by the unburned average to obtain a relative measure of species performance in relation to fire (burned to unburned cover ratio)]

\begin{tabular}{|c|c|c|c|c|}
\hline \multirow{2}{*}{ Taxon } & \multirow{2}{*}{$\begin{array}{l}\text { Growth } \\
\text { form }\end{array}$} & \multicolumn{2}{|c|}{ Number of plots } & \multirow{2}{*}{$\begin{array}{l}\text { Burned/unburned } \\
\text { cover ratio }\end{array}$} \\
\hline & & Unburned & Burned & \\
\hline Adenophyllum porophylloides & Subshrub & 10 & 5 & 7.458 \\
\hline Ambrosia deltoidea & Shrub & 5 & 4 & 0.332 \\
\hline Ambrosia dumosa & Shrub & 2 & 2 & 0.161 \\
\hline Ayenia sp. (filiformis) & Subshrub & 4 & 3 & 0.549 \\
\hline Bouteloua curtipendula & Grass & 4 & 4 & 1.561 \\
\hline Calliandra eriophylla & Shrub & 9 & 8 & 1.481 \\
\hline Chamaesyce sp. & Forb & 8 & 6 & 1.833 \\
\hline Cirsium neomexicanum & Forb & 1 & 1 & 0.817 \\
\hline Ditaxis sp. (lanceolata, neomexicana) & Forb & 3 & 4 & 1.368 \\
\hline Eriogonum fasciculatum & Shrub & 8 & 10 & 0.347 \\
\hline Fagonia laevis & Subshrub & 1 & 1 & 2.864 \\
\hline Galium stellatum & Shrub & 5 & 5 & 0.697 \\
\hline Krameria erecta & Shrub & 9 & 8 & 1.171 \\
\hline Krameria sp. & Shrub & 2 & 1 & 0.998 \\
\hline Lotus rigidus & Forb & 7 & 4 & 3.632 \\
\hline Lycium berlandieri & Shrub & 4 & 2 & 15.133 \\
\hline Lycium sp. & Shrub & 7 & 7 & 1.128 \\
\hline Opuntia engelmannii & Cactus & 2 & 5 & 1.344 \\
\hline Parkinsonia microphylla & Tree & 11 & 11 & 0.552 \\
\hline Pleuraphis rigida & Grass & 6 & 7 & 2.362 \\
\hline Porophyllum gracile & Subshrub & 7 & 5 & 1.906 \\
\hline Simmondsia chinensis & Shrub & 6 & 6 & 0.731 \\
\hline Sphaeralcea ambigua & Forb & 12 & 8 & 2.173 \\
\hline Tridens muticus & Grass & 5 & 4 & 1.480 \\
\hline Viguiera parishii & Shrub & 6 & 7 & 1.104 \\
\hline
\end{tabular}


Table 9. Indicator species analysis for perennial plant species partitioned by burn status (burned or unburned).

[Analyses also were conducted hierarchically within each decade of the study. All species observed during the study were analyzed, but only those with significant patterns are displayed here. Significance levels are indicated by asterisks $(* P<0.05$, $* * P<0.01, * * * P<0.001)$. Tortoise food species are identified according to Van Devender and others, 2002; Tortoise cover ranks are on a scale of $0-3$ and are assigned by expert opinion]

\begin{tabular}{|c|c|c|c|c|c|c|}
\hline Perennial plant species & Food & Cover rank & $1980 \mathrm{~s}$ & $1990 \mathrm{~s}$ & $2000 \mathrm{~s}$ & All decades \\
\hline \multicolumn{7}{|c|}{ Burned } \\
\hline Lotus rigidus & Yes & 2 & $* * *$ & & & $* *$ \\
\hline Sphaeralcea ambigua & Yes & 2 & & $*$ & & \\
\hline Porophyllum gracile & Yes & 1 & & & $* *$ & \\
\hline Adenophyllum porophylloides & Yes & 1 & & $* * *$ & & $* * *$ \\
\hline Stephanomeria pauciflora & Yes & 0 & & & & $*$ \\
\hline Aristida purpurea & Yes & 1 & & $* * *$ & $*$ & $*$ \\
\hline Encelia farinosa & No & 2 & & & $* * *$ & \\
\hline Bebbia juncea & No & 2 & & * & & \\
\hline Gutierrezia sarothrae & No & 1 & & $* *$ & & \\
\hline Senna covesii & No & 1 & & & & $*$ \\
\hline Dichelostemma capitatum & No & 0 & & & & $* *$ \\
\hline \multicolumn{7}{|c|}{ Unburned } \\
\hline Eriogonum fasciculatum & Yes & 1 & $* * *$ & $*$ & & $* * *$ \\
\hline Echinocereus engelmannii & Yes & 1 & & & $*$ & \\
\hline Larrea tridentata & No & 3 & & $* * *$ & & $* * *$ \\
\hline Yucca baccata & No & 3 & * & & & $* *$ \\
\hline Cylindropuntia acanthocarpa & No & 2 & & $*$ & & $* *$ \\
\hline Encelia frutescens & No & 2 & & & * & \\
\hline Fouquieria splendens & No & 1 & & $*$ & $*$ & $* * *$ \\
\hline Menodora scabra & No & 1 & $* *$ & & & \\
\hline
\end{tabular}



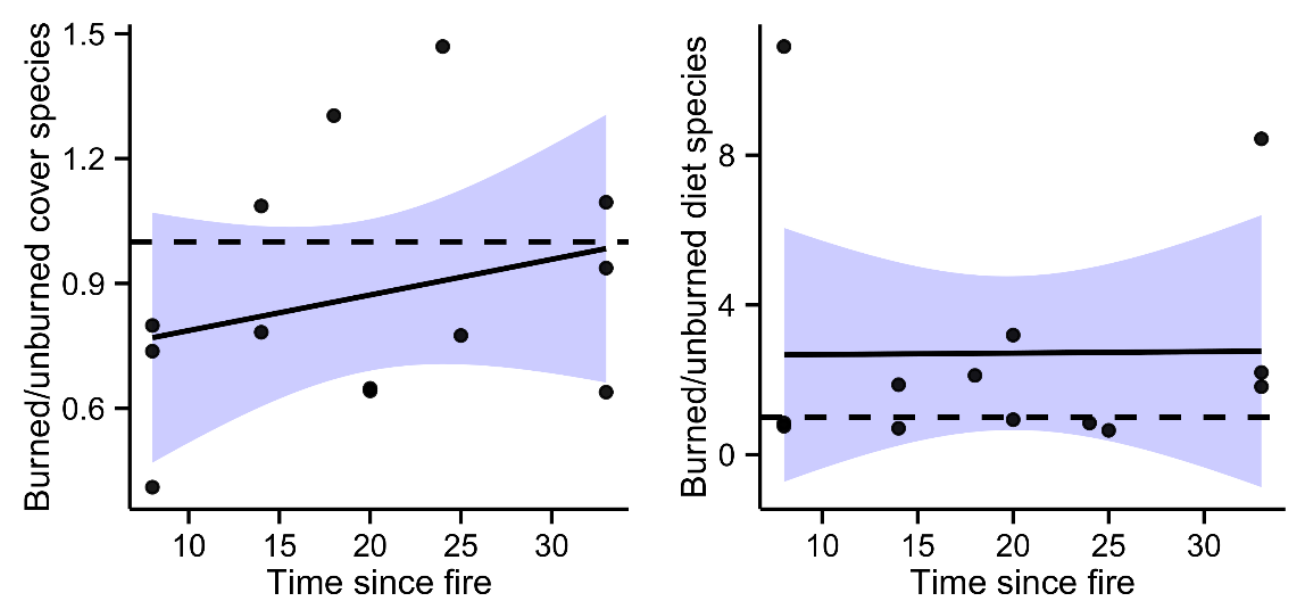

Figure 8. Burned/unburned ratios of percentage cover for perennial plant species aggregated into tortoise-use categories: cover species (left panel) and food species (right panel). For each fire ( $n=13$, black circles in figure), a burned/unburned ratio was calculated by first averaging the percentage cover values for perennial species in each tortoise use category (cover and food) and burn status (burned/unburned), and then dividing the burned average value by the unburned average value. Solid lines indicate the regression of burned/unburned ratios against TimeSince-Fire for each fire and tortoise use category, and shaded bands indicate the 95-percent confidence interval surrounding the regression. Neither regression was statistically significant. Dashed lines indicate a ratio of 1 (that is, equal between burned and unburned areas).

The OMI analysis identified 20 tortoise food or cover species (fig. 9) that showed a significant $(P<0.05)$ response to the ordination axis constraints (burn treatment and TSF). The mean positions of these 20 species in relation to burn treatment and fire are shown in an ordination plot (fig. 9), and the standard deviations of these species' distributions along each ordination axis are shown in figure 10. Taxa such as Senna covesii, Adenophyllum porophylloides, Sphaeralcea ambigua, and Dichelostemma capitatum occurred more abundantly in recently burned areas (fig. 9). In contrast, taxa such as Yucca baccata and Opuntia englemannii characterize intact sites that have not burned or have had decades to recover, respectively. These results are important because they emphasize that tortoise food species such as Sphaeralcea ambigua and Adenophyllum porophylloides along with the high-quality cover species Encelia farinosa (table 9), which is known to be used extensively by the Mojave Desert Tortoise (Nussear, 2004; Lovich and others, 2011; Nussear and Tuberville, 2014), can show increased abundance in burned areas. Opuntia englemannii also is particularly important because it provides cover as well as nutritious fruits that are much sought after by Sonoran Desert Tortoises. However, because this species takes many years to reestablish (fig. 9), it may be a candidate for enhancement by restoration methods. Many Opuntia can be readily established simply by planting cuttings. 


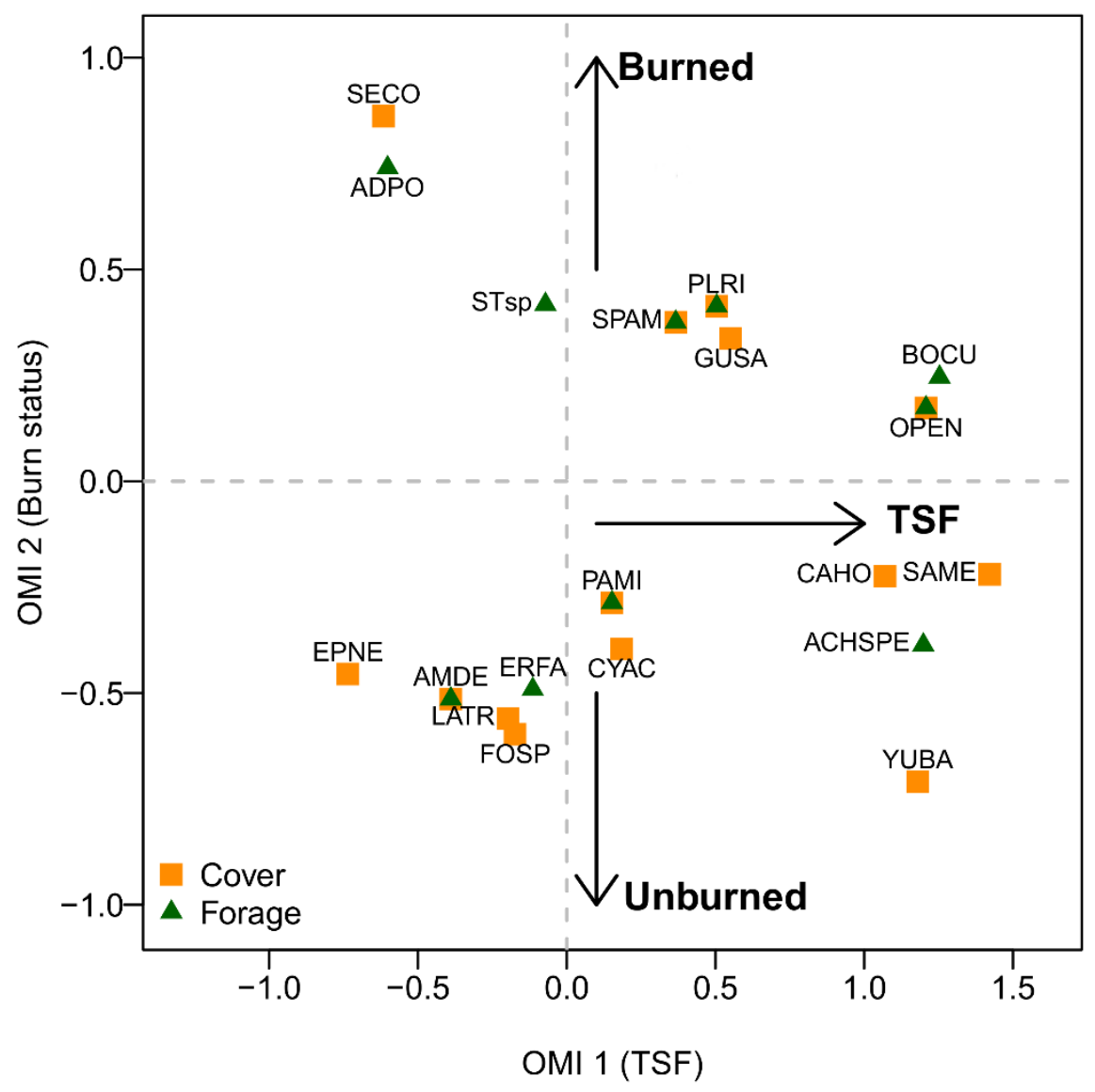

Figure 9. Outlying Mean Index (OMI) ordination analysis of perennial species response to fire through time (Time-Since-Fire, or TSF). Species are categorized according to their value as cover (squares) or food (triangles) for tortoises. Only species with significant $(P<0.05)$ index values are shown. The ordination plot shows the mean position of species in relation to TSF (X-axis) and burn status (Y-axis), and the lower figures show the breadth of species distributions in relation to these factors. Species codes: EPNE, Ephedra nevadensis; AMDE, Ambrosia deltoidea; LATR, Larrea tridentata; FOSP, Fouquieria splendens; ERFA, Eriogonum fasciculatum; CYAC, Cylindropuntia acanthocarpa; PAMI, Parkinsonia microphylla; CAHO, Canotia holacantha; ACHSPE, Achnatherum speciosum; SAME, Salazaria mexicana; YUBA, Yucca baccata; SECO, Senna covesii; ADPO, Adenophyllum porophylloides; STsp, Stephanomeria spp.; SPAM, Sphaeralcea ambigua; PLRI, Pleuraphis rigida; GUSA, Gutierrezia sarothrae; BOCU, Bouteloua curtipendula; and OPEN, Opuntia englemannii. 


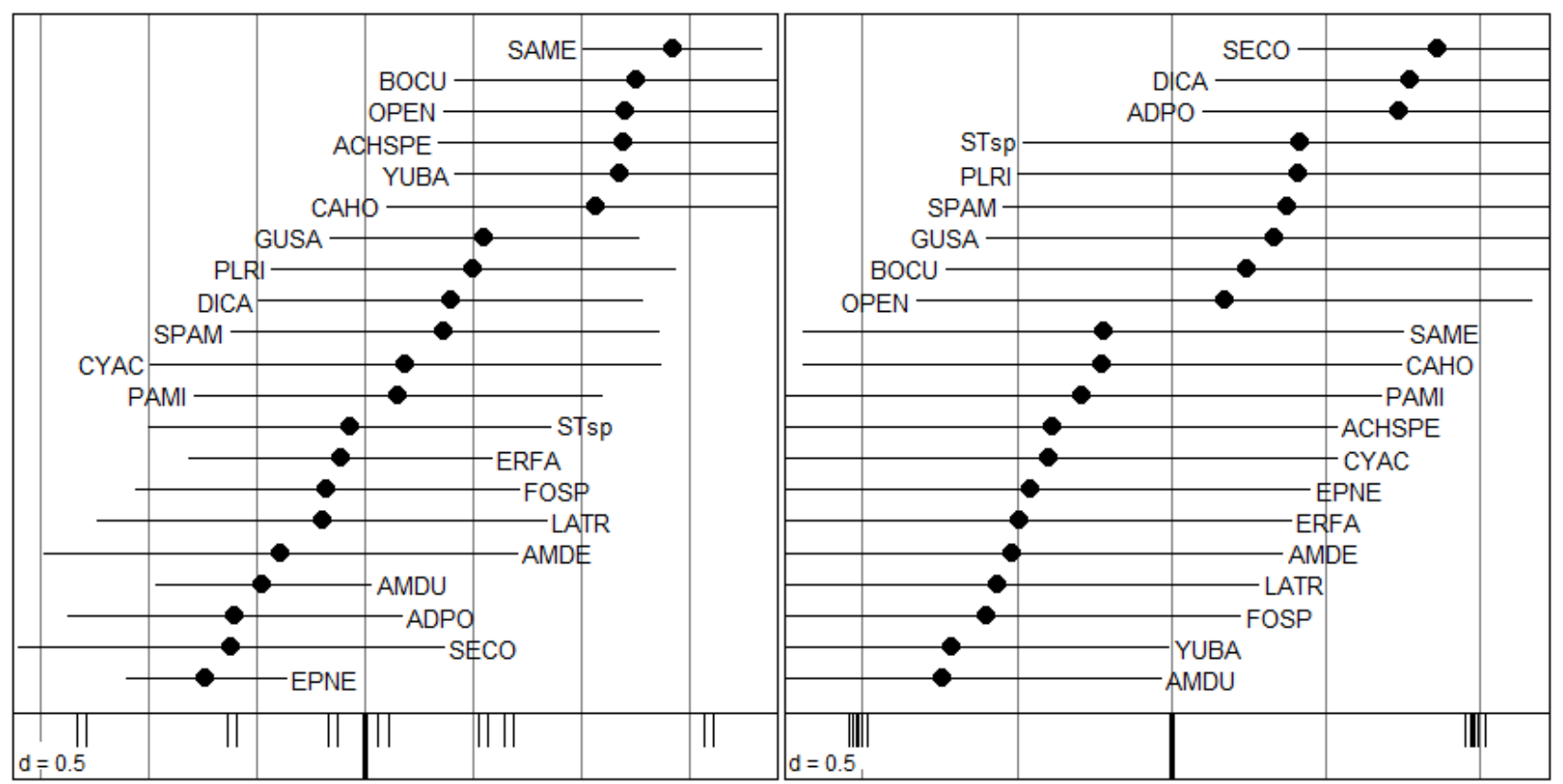

Figure 10. Breadth of perennial species distributions in relation to Time-Since-Fire ( $x$-axis, left) and burn status (y-axis, right). Species codes are shown in figure 9 . The thick black line at the bottom of each panel indicates the origin of the respective Outlying Mean Index axis (X- left panel; Y- right panel).

\section{Discussion}

Our study is the first to examine the relative influences of environmental filters (abiotic conditions) and TSF on vegetation assembly and recovery patterns following wildfires in the Sonoran Desert. Understanding these influences is essential for predicting the response of this ecosystem to a novel fire regime and forecasting effects on the habitat of sensitive species such as the desert tortoise. Collectively, our results suggest that environmental filters play a greater role than TSF at each scale of our analysis, from species and growth form composition through vegetation structure and landscapescale recovery patterns (fig. 11). At the finest scale, perennial species and growth form composition did not show a directional trend corresponding with TSF, but did show persistent differences between burned and unburned control areas. The nature of these differences was shaped largely by abiotic conditions. At the habitat structure level, vegetation cover and height were reduced by fire, with recovery more strongly related to abiotic conditions than to TSF. In contrast, plant density was initially increased by fire, but decreased through time until it resembled unburned conditions in the oldest $(\mathrm{TSF}>30)$ burn areas. This temporal trend was mediated by annual precipitation, however, in that larger relative increases in plant density occurred in burned areas receiving lower annual precipitation. Finally, at a landscape scale, simple topographic (elevation) or climatic (average annual precipitation, post-fire precipitation) variables were much better predictors of vegetation recovery than TSF. These results provide compelling evidence that the environmental-filter hypothesis is applicable to post-fire vegetation assembly in the Sonoran Desert, but they do not support our initial hypothesis that species and growth form composition would be more strongly influenced by environmental filters than would overall vegetation cover, height, or density. However, our second hypothesis was largely supported, in that most measured vegetation properties did not show a full recovery to undisturbed conditions. 

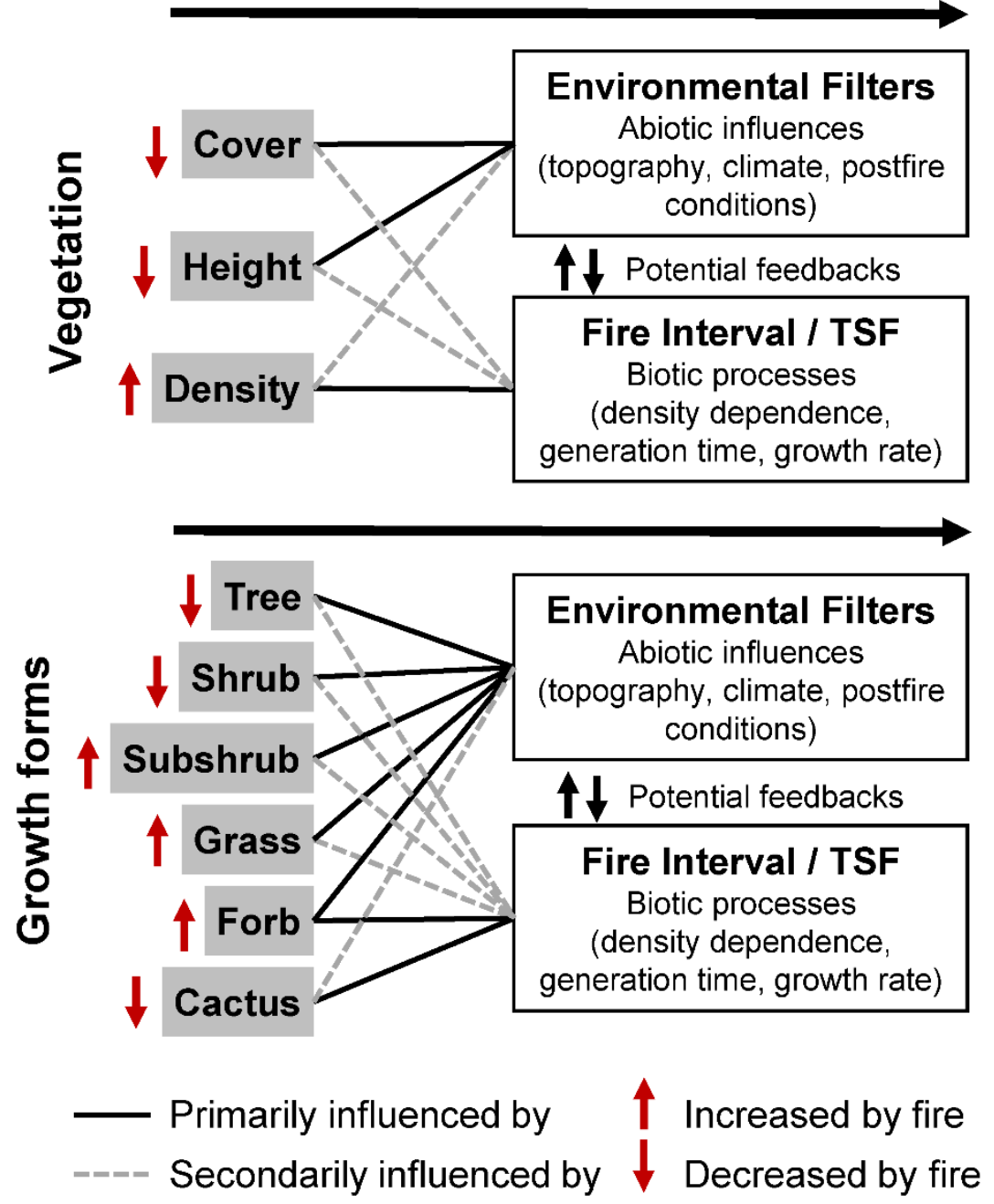

Figure 11. Conceptual model showing the relative influence of environmental filters and Time-Since-Fire (TSF) in shaping the response of community-scale vegetation attributes (cover, height, density) and perennial growth forms to fire, based on a chronosequence of once-burned areas ranging in TSF from 8 to 33 years. 


\section{Species and Growth-Form Responses to Fire}

The reasoning behind our initial hypothesis was that environmental filters act predominantly on species traits, favoring species with attributes that increase fitness (Keddy, 1992; Moretti and Legg, 2009). Therefore, vegetation recovery following disturbance reflects the important habitat filtering processes of the disturbed environment, and trait convergence may occur when the disturbance is novel (that is, imposing a filter that removes non-adapted species; Grime, 2006; Smart and others, 2006). Our results suggest that species and growth form responses to fire were influenced by topography and climate to a greater extent than TSF. The dominant shrub and tree species of this ecosystem (for example, Larrea tridentata and Parkinsonia microphylla, respectively) were most reduced, whereas forbs, grasses, and subshrubs increased after fire. Certain abiotic conditions accentuated differences in growth form composition between burned and unburned areas, such as the greater relative increase in subshrub, grass, and forb cover with increasing elevation or slope in burned areas (fig. 4b, e, and f). However, forbs and cacti also showed directional but opposing temporal trends in cover, with increasing TSF - forbs had over twice as much cover, and cacti had less than one-half the cover, in burned relative to unburned areas in the first post-fire decade. When fires were older than 20 years, these differences were no longer apparent. Both growth forms typically are fire-killed, obligate seeders (Brooks and Minnich, 2006), although certain perennial forbs present at our study areas may resprout from belowground organs (for example, Mirabilis laevis, Dichelostemma capitatum). Increases in forb cover immediately following desert fires have been noted in other studies (for example, Abella and others, 2009; Steers and Allen, 2011) and suggest that perennial forbs are able to quickly regenerate in these environments. In contrast, cactus life cycles typically are slow and are characterized by long life-spans, episodic recruitment, and large, animal-dispersed seeds (Godínez-Alvarez and others, 2003) — traits that are not favored by fire in deserts (Shryock and others, 2014). However, in our study, some cacti (for example, Cylindropuntia spp., Opuntia. spp., and Echinocereus sp.) still showed greater regeneration potential than shrubs or trees (fig. 3b), particularly with higher annual precipitation (fig. 4c).

Collectively, our results suggest that intraspecific differences in recovery were driven by the interplay between spatially variable abiotic gradients and fundamental aspects of the life histories of the species that shape resource use, physiological tolerances to abiotic stress, and regeneration rates.

We detected persistent, non-directional differences in post-fire species composition, but do these differences constitute alternative stable states? Criteria that define alternative stable states include:

1. The change in vegetation state from a single disturbance pushes the initial community past a threshold, after which the alternative state is not maintained by repeated perturbations;

2. Multiple states can exist within the same environment, depending on which species can successfully establish itself in the immediate post-disturbance environment; and

3. The alternative state is stable through time and maintained by autogenic (internal, biotic) rather than allogenic (external, abiotic) processes (Schröder and others, 2005; Mason and others, 2007).

Our evaluation of once-burned areas clearly meets criterion 1. Given our space-for-time approach, we are not able to determine the influence of historical contingency effects (i.e., colonization history, criterion 2). However, our results seem to be inconsistent with criterion 3 , in that species and growth form composition were predominantly and individually sorted along spatially variable abiotic gradients, rather than forming distinct associations maintained by autogenic processes. Furthermore, had alternative stable states become established, we would not expect to see the directional trends in cacti and forb cover (fig. 4c and f) or in overall plant density (fig. 5b), all of which showed increasing similarity to unburned control sites through time. Alternative stable state theory also assumes that the alternative community has had sufficient time to stabilize, meaning that all species have had time to 
regenerate (Schröder and others, 2005). Even in undisturbed conditions, long-lived desert trees and shrubs exhibit slow population growth, with episodic recruitment and potentially multi-decadal generation times (Goldberg and Turner, 1986; Cody, 2000; Reynolds and others, 2012). Thus, insufficient time may have elapsed for these species to reestablish themselves at our study areas through natural processes. Therefore, there is insufficient evidence to conclude they would be incapable of doing so following a single fire at longer TSFs. Given these considerations, our results are more aligned with an environmental-filter based model, in which post-fire vegetation recovery is determined by dispersal limitations and abiotic conditions that restrict which species from among those available in the total species pool are able to establish themselves at a given site (Belyea and Lancaster, 1999).

\section{Vegetation Recovery from Fire at the Structural and Landscape Scales}

Vegetation cover was strongly influenced by elevation and average annual precipitation (fig. 5a), and elevation also was the strongest predictor of recovery at the landscape scale (fig. 7a). Elevation and annual precipitation were only weakly correlated across our study areas $(r=0.29)$, but both indicate gradients in resource availability and exposure. Interactions between precipitation, soil texture, and temperatures vary along elevation gradients because of alluvial processes and orographic uplift, profoundly influencing the distribution of desert vegetation, particularly long-lived shrubs and trees that contribute most to overall cover (Parker, 1991; Medeiros and Drezner, 2012). Thus, our results suggest that abiotic conditions are the primary limiting factor for long-term, post-fire reestablishment of vegetation cover in the Sonoran Desert, accounting for the lack of a strong temporal trend in burned/unburned cover ratios across our study areas (fig. 7a). Rather, recovery rates varied spatially along elevation and precipitation gradients. Similar results have been obtained in semi-arid savanna (Levick and others, 2012) and Mediterranean shrublands (Keeley and others, 2005).

Average vegetation height along transects primarily was influenced by annual precipitation, whereas post-fire precipitation was the strongest predictor of recovery in vegetation height at a landscape scale. Given that resprouting species typically reestablish faster than seedlings, these relationships likely are indicative of the post-fire resprouting rate, which is physiologically limited by low precipitation in arid environments but increases with increasing precipitation (Pausas and Bradstock, 2007; Nano and Clarke, 2011). Low to moderate levels of resprouting have been recorded for Sonoran Desert species (Rogers and Steele, 1980; McLaughlin and Bowers, 1982; Cave and Patten, 1984; Wilson and others, 1995), but the relationship between resprouting and precipitation has not been directly quantified. However, our results provide indirect evidence that the amount of precipitation received in the first post-fire year has substantial long-term effects on vegetation structure in the Sonoran Desert. This result is likely owing to immediate post-fire precipitation that increases the proportion of perennial plants that survive through resprouting.

Plant density increased in burned relative to unburned areas during the first decade following fire, but this difference became less apparent with longer TSFs (fig. 5b). Similar post-fire increases in density have been noted at other Sonoran Desert sites (Steers and Allen, 2011), although density is often reduced in the first few post-fire years (Rogers and Steele, 1980; McLaughlin and Bowers, 1982; Cave and Patten, 1984). Our study suggests that subshrubs, grasses, and forbs increase vegetation density through seedling establishment during the first post-fire decade (fig. 4b, e, and f), but that these differences are not persistent over the long-term. Return to pre-burn density levels could reflect either density-dependent competitive interactions or the longevity of seedling cohorts that become established soon after fire, but do not regenerate continuously thereafter. Our results also suggest that post-fire increases in density are mediated by abiotic conditions, particularly annual precipitation. Although resprouting tends to increase with precipitation, obligate post-fire seeding species are more abundant in 
areas receiving less annual precipitation (Pausas and Bradstock, 2007; Nano and Clarke, 2011), potentially because of reduced competition from resprouting species (Clarke and others, 2005). This relationship may explain the negative correlation we detected between annual precipitation and density, which was the strongest predictor of the burned/unburned density ratio at a landscape scale.

The Arizona Upland Subdivision of the Sonoran Desert receives roughly twice the precipitation of most of the Mojave Desert (Nussear and Tuberville, 2014). In combination with heterogeneity of landscape features (boulder fields, slopes, and northerly aspect), higher precipitation may facilitate opportunities for more rapid recovery of vegetation structure in the Sonoran Desert compared to the less topographically complex Mojave Desert. For example, slope and aspect interact to create microsites with a broad spectrum of temperatures. North-facing slopes reduce solar insolation, thereby decreasing evaporation and conserving soil moisture, which can provide important opportunities for establishment and growth of plant species and protection for wildlife. Landscape features, such as boulder fields, cliff faces, and deeply incised washes, provide further habitable microsites where cool temperatures and soil moisture are conserved. In this study, we find that resource-rich habitat patches created by a heterogeneous topography show accelerated recovery of vegetation structure following a single fire compared to harsher microsites within the same landscape. Forbs, grasses, and subshrubs are particularly capable of recovery on high-elevation, north-facing slopes, and may show greater relative abundance in burned areas where these topographic conditions occur. Although more arid and less topographically complex Mojave Desert landscapes may require at least 40 years to achieve pre-fire cover (Abella, 2009), our results show that topographically favorable sites in the Sonoran Desert require much less time to meet the same standard.

A question that remains to be addressed is the time-scale at which post-fire environmental filters are most influential in shaping perennial vegetation composition and structure. In other words, do abiotic conditions influence species composition to a greater extent in early post-fire years, or continuously through time? Of the filtering effects we detected, only the relationship between vegetation height and post-fire precipitation clearly indicates a short-term influence (with long-term implications), whereas the time scale at which other relationships are most important - for example, the correlation between recovery of vegetation cover and elevation - is unclear. Understanding whether these mechanisms represent immediate or continuous influences could substantially improve predictions of post-fire vegetation change. For example, Harvey and Holzman (2014) found that the early influence of topographic position on seedling establishment resulted in divergent long-term successional trajectories following fire in a closed-cone pine forest. Given our results, it is possible that topography plays a similar role in the Sonoran Desert. Knowledge of the extent to which early post-fire environmental filters (for example, post-fire precipitation) shape longer term successional trajectories could aid in targeted management strategies and predictions of effects on wildlife habitat. However, developing such inferences requires long-term, post-fire monitoring across a range of sites, rather than the space-for-time approach adopted here.

The extent to which biotic processes interact with environmental filters to influence post-fire vegetation change is an additional question in need of further research. Facilitative interactions involving nurse plants are nearly ubiquitous in desert environments (Butterfield and others, 2010) and increase seedling establishment and survival by modulating the effects of precipitation (Tielbörger and Kadmon, 2000; Butterfield and others, 2010) and affording protection from herbivores (McAuliffe, 1986; Holland and Molina-Freaner, 2013). Researchers have speculated that the lack of large shrubs and trees could slow post-fire recovery of desert vegetation by limiting facilitative interactions (Abella, 2009). Conversely, overall vegetation recovery may be faster where the dominant shrubs and trees are able to resprout (Arnan and others, 2007). In this way, environmental filters that shape vegetation 
composition and recovery in the immediate post-fire environment (for example, post-fire precipitation) could influence long-term successional trajectories if the initial spatial variability is maintained by subsequent biotic processes. The degree to which landscape scale variability in post-fire vegetation assembly is maintained by synergistic interactions between environmental filters and biotic interactions (for example, competition, facilitation) warrants further study. We represent these potential feedbacks as arrows in our conceptual model (fig. 11).

An important caveat regarding this study is that we documented changes in Sonoran Desert vegetation following single fires in areas with no known history of previous burns. However, repeated burning of vegetation in this system could result in additional reductions to vegetation structure, as appears to be the case with Mojave Desert vegetation (Brooks, 2012). Similarly, although our results did not support the presence of alternative stable states, continued encroachment of invasive annual plants and subsequent re-burning of large areas may alter baseline conditions to a sufficient extent to trigger more severe changes in species composition.

\section{Perspectives on Post-Fire Vegetation Change and the Sonoran Desert Tortoise}

This study documented post-fire vegetation changes in the Arizona Upland Subdivision of the Sonoran Desert, which is one of the most important habitat types for the Sonoran Desert Tortoise (Van Devender, 2002; Nussear and Tuberville, 2014). The post-fire environment may affect desert tortoise ecology through changes in the availability, diversity, abundance, and type of food plants, along with changes in the availability of cover for protection from thermal extremes and predators (Brooks and Esque, 2002; Esque and others, 2003; Snyder, 2014; Drake and others, in press). However, vegetation burned multiple times either in the Sonoran or Mojave Deserts tends to lose additional plant diversity (Turner and others, 2010) and structure (Brooks, 2012), and our results may not be fully applicable to these settings. Thus far, the effects of changes accompanying repeated burning have not been studied in the Sonoran Desert.

Our analyses illustrated that, although the perennial species composition of vegetation communities certainly changes as a result of fire, the responses of species vary considerably among growth forms. Although many trees, shrubs, and succulents are reduced by fire, other subshrubs, forbs, and grasses can be increased by fire. In particular, forbs, grasses, and subshrubs showed increased cover on burned sites at higher elevations and on north-facing slopes. Many of these species have the ability to resprout, or reseed readily, and some of these short-lived perennials are ruderal species, such as Encelia farinosa, that rapidly recolonize following habitat disturbance (Lovich and others, 2011). When fires are not so severe as to completely eliminate these initial colonizers, such species likely provide favorable microclimates for the germination, establishment, and growth of other, longer lived species that require nurse plants to thrive (Franco and Nobel, 1988; McAuliffe, 1988; Butterfield and others, 2010). For example, yellow paloverde (Parkinsonia microphylla) showed significantly decreased cover in burned areas (table 3), but also significantly increased density (appendix C, table C2), suggesting that recovery through seedling establishment is taking place. Furthermore, although many woody species of trees and shrubs are diminished for 1-2 decades following a single fire, these species frequently are replaced by shorter lived perennials and annuals that still provide cover and food for tortoises, mitigating the effects from fire.

This study documented changes in only a subset of the plants that comprise Sonoran Desert Tortoise diets because of its limited time frame. Sonoran Desert Tortoises benefit not only from perennial species but also from two entirely different annual plant floras that may become available in spring or summer, depending on seasonal precipitation and temperature (Van Devender and others, 2002; Esque and others, 2014). These species show a highly complex response to fire that likely is 
mediated by post-fire climatic conditions and competitive interactions with other species (Brooks, 2000; DeFalco and others, 2003). Although some desert annuals may be lost (Esque and others, 2010a; Brooks, 2012), other species can benefit from the reduction in perennial plant competition and flourish with adequate precipitation and favorable temperatures. The response of the summer annual flora to fire in the Sonoran Desert is little understood, as existing studies have focused largely on winter annual species (Esque and others, 2010a). This may be an important avenue for future long-term research, given that summer annuals may be particularly important to tortoises in the Sonoran Desert (Van Devender and others, 2002).

One of the greatest indirect threats linked to desert wildfire is the potential dominance by invasive plant species that may outcompete native species, or promote the grass/fire cycle, thus eliminating the diversity and structure of habitats (D'Antonio and Vitousek, 1992; Esque and Schwalbe, 2002). In particular, the invasive annual grass red brome (Bromus rubens) occurs widely in desert tortoise habitats across the Mojave and Sonoran Deserts (Hansen and others, 1976; Esque, 1994; Jennings, 2002; Van Devender, 2002; Esque and others, 2014), and can be the most ubiquitous of the invasive species following fire in the Arizona Upland Subdivision of the Sonoran Desert during years of abundant winter precipitation (Salo, 2004). Although our results indicated that red brome was equally abundant between burned and unburned reference areas (appendix D), a single-year study is not wellsuited to analyze the distribution and abundance of any annual species. Red brome can affect native vegetation and tortoises by increasing the abundance and continuity of fine fuels, thereby promoting wildfire. However, red brome also may alter native vegetation through other mechanisms. For example, this species has greater competitive ability than native annuals (DeFalco and others, 2003), but is less effective at competing with some desert shrubs, subshrubs, and forbs (Abella and others, 2012).

Furthermore, red brome typically germinates in response to heavy winter rains (Brooks, 2000), and thus competes with the winter/spring flora of annual and perennial plants, but not the summer flora, which is possibly even more important to tortoises in the Sonoran Desert (Van Devender and others, 2002).

The abundance of red brome in Sonoran Desert Tortoise habitat also may influence tortoise diet and consequently health, particularly for juvenile tortoises. Red brome may be preferred over a variety of foods for some individual tortoises (Esque, 1994), although most tortoises prefer a diverse diet when available (Jennings, 2002; Esque and others, 2014; Jennings and Berry, 2015). Injuries associated with brome grasses include perforation of the skin, nares, and eyes. Furthermore, the stiff awns can become impacted inside the mouth of desert tortoises, potentially causing injury and interfering with eating (Medica and Eckert, 2007). Early work on nutrition of tortoise food plants indicated that grasses generally had lower dry matter and energy digestibility and very little nitrogen compared to forbs (Nagy and others, 1998; Hazard and others, 2010). Recent nutritional studies have indicated that juvenile tortoises fed fresh brome grass grow more slowly and have lower survivorship than those fed mixtures of native annual forbs (Nussear and others, unpub. data, 2015). In comparison to other diet and feeding studies of adult tortoises, either in the laboratory or natural conditions, juvenile desert tortoises appear to be more susceptible to brome grass in their diets, and additional work is required to determine exactly how important this difference in susceptibility may be for the overall demography of the species.

The invasive perennial, buffelgrass, was only discovered on one of the study areas, and the degree to which this species may threaten tortoise habitat is largely unknown and speculative. Buffelgrass is now widespread in some natural areas, and its windborne seeds likely are moved along transportation corridors. We speculate that the proximity of burned areas to highway margins that can act as a seed source could influence the probability of invasion by this species. An increase in buffelgrass abundance within desert tortoise habitat could be grounds for concern because the grass likely is too coarse to be a preferred tortoise food, and although it could afford cover, it often forms 
dense stands that may be difficult for tortoises to travel through. Additionally, ecophysiological modeling results have suggested that buffelgrass stands may be too hot for tortoises and may decrease the available time for them to remain active (B. Sinervo, oral commun., University of California, Santa Cruz, 2015). Furthermore, buffelgrass provides sufficient fuel to create very intense fires (Esque and others, 2006), although to date (2015) there have not been many large fires or loss of property sufficient to cause great alarm with regard to human health and safety in the Sonoran Desert study region.

Desert wildfires reduce vegetation cover, which is important to tortoises seeking cover from thermal extremes and protection from predators (Esque and Schwalbe, 2002; Esque and others, 2003; Nussear and Tuberville, 2014). This loss of vegetation theoretically results in a challenging habitat to tortoises, although there are no published studies documenting the importance of such changes for the Sonoran Desert Tortoise. However, one comparative analysis between burned and unburned habitat at Saguaro National Park indicated that tortoises did not emigrate from the burned area, and post-fire survival was not significantly different among adult tortoises between unburned and burned areas (T.C. Esque and C.R. Schwalbe, U.S. Geological Survey, unpub. data, 2015). Furthermore, long-standing hypotheses that burned Mojave Desert Tortoise habitat is quite harsh for tortoises (Brooks and Esque, 2002; Esque and others, 2003) have been questioned by recent studies indicating that home range size, activity, growth, reproductive output, thermoregulation potential, and survivorship did not differ between adult desert tortoises in burned and nearby unburned habitat during 7 years following a wildfire in southern Nevada (Snyder, 2014; Drake and others, in press). In these studies, tortoises responded to variation in the availability of post-fire vegetation, moving farther into the burned area each year subsequent to the fire, and then retreating to unburned edges during a population crash of Sphaeralcea ambigua, the favored food and cover plant in the burned areas. We hypothesize that the variability in slope, aspect, and physiognomy (for example, boulder strewn hillsides, and arroyos with caliche caves, crevices, and boulders) characteristic of Sonoran Desert Tortoise habitat provides a diverse and useful variety of thermal refugia that is much more diverse than that found in most Mojave Desert Tortoise habitats (Germano and others, 1994; Van Devender, 2002; Nussear and Tuberville, 2014), potentially mitigating the effects of wildfire in this environment.

Although certain general hypotheses regarding adult tortoise behavior and health in burned habitats of the Mojave Desert have been refuted, similar work has yet to be conducted on tortoises with smaller body sizes. As with diet and nutrition, young tortoises may be more susceptible to losses of vegetation cover than adults. The ability of tortoises to thermoregulate is mediated by body size (Hillard, 1996; Nussear, 2004). Larger tortoises have greater thermal inertia and potentially can use habitat where thermal cover has been reduced to a greater extent than can smaller tortoises.

Furthermore, larger tortoises have greater mobility than juveniles, increasing their potential for behavioral thermoregulation (Morafka and others, 2000). Thus, reductions in vegetation cover in burned areas, along with changes in food availability or diversity, could be particularly influential to the survival of juvenile desert tortoises and their recruitment into larger size classes. This issue requires further attention to understand the role of fire in the ecology of the Sonoran Desert Tortoise.

\section{Conclusions and Future Directions}

Fire markedly altered Sonoran Desert vegetation communities at different levels of community organization (species, vegetation structure, and landscape) and across a range of Time-Since-Fires (TSFs; 8-33 years). We found strong support for the environmental-filter hypothesis, in that post-fire vegetation assembly was influenced more by abiotic factors - particularly precipitation and elevationthan by TSF at all scales of our analysis. For example, responses of species to fire were sorted along topographic and precipitation gradients, and varied by growth form. Paralleling this result, landscape- 
scale recovery of vegetation cover, height, and density showed closer correspondence to gradients in elevation, post-fire precipitation, and annual precipitation, respectively, than to recovery time.

Vegetation structure recovered faster as elevation and average annual precipitation increased, but growth form composition showed less similarity to unburned conditions under the same conditions owing to increased forb, grass, and subshrub cover. The amount of precipitation received in the first year following fire may have long-term consequences for vegetation structure. These results suggest that spatial variability in topography and climate within vegetation types can be more influential than TSF in shaping post-fire vegetation recovery. Therefore, abiotic conditions could beneficially be incorporated in applications of post-fire vegetation modeling, as well as fire-management and restoration strategies.

Given the recent work highlighting use of burned habitat by adult tortoises in the Mojave Desert, results suggest that the increased availability of food plants in burned Sonoran Desert Tortoise habitat, coupled with thermal refugia afforded by a heterogeneous topography, likely enable adult Sonoran Desert Tortoises to continue to use burned habitat. However, much of the existing knowledge base is centered on adult tortoises, whereas juveniles likely face additional challenges in the post-fire environment. Tortoises of smaller body size have less mobility to explore the landscape, less access to food plants by their short stature, and less thermal inertia; thus, their potential active periods may be shorter in the summer. Additionally, red brome (Bromus rubens) and other invasive grasses are abundant in both the Mojave and Sonoran Deserts, may increase in abundance following wildfire, and may reduce the growth or survival of juvenile desert tortoises. Hence, there is an urgent need to understand whether juvenile desert tortoises are more susceptible to fire and invasive species than adults. For example, could red brome contribute to low recruitment in spite of all the other recovery efforts? Carefully designed and implemented restoration projects may contribute to our understanding of this dilemma.

Over the long term, repeated burning of desert tortoise habitat in the Sonoran Desert may pose additional challenges beyond those reported here. At present, the effects of multiple fires on Sonoran Desert vegetation and tortoises are little understood. However, these effects are likely to include direct losses of tortoises during burns, additional reductions of vegetation structure, lasting alterations to species composition, and favorable conditions for the spread of invasive plant species. Hence, it will be important to monitor the fire regime in Sonoran Desert Tortoise habitat for indications of a continued shift towards shortened fire-return intervals.

\section{Acknowledgments}

We thank T. Hughes of the Bureau of Land Management-Arizona for supporting logistical coordination, and sharing his knowledge of the topics. Thanks to R. Sanchez of the U.S. Forest Service for providing information and coordinating about additional wildfires that we studied. L.A. DeFalco, R.C. Averill-Murray, and K.E. Nussear provided reviews on earlier drafts of this manuscript. 


\section{References Cited}

Abella, S.R., 2009, Post-fire plant recovery in the Mojave and Sonoran Deserts of western North America: Journal of Arid Environments, v. 73, p. 699-707.

Abella, S.R., Craig, D.J., Smith, S.D., and Newton, A.C., 2012, Identifying native vegetation for reducing exotic species during the restoration of desert ecosystems: Restoration Ecology, v. 20, p. 781-787.

Abella, S.R., Engel, E.C., Lund, C.L., and Spencer, J.E., 2009, Early post-fire plant establishment on a Mojave Desert burn: Madroño, v. 56, p. 137-148.

Alford, E.J., 2001, The effects of fire on Sonoran Desert plant communities: Phoenix, Arizona State University, Ph.D. thesis.

Anderson, D.R., 2008, Model based inference in the life sciences-A primer on evidence: New York, Springer.

Anderson, M.J., 2001, A new method for non-parametric multivariate analysis of variance: Austral Ecology, v. 26, p. 32-46.

Arnan, X., Rodrigo, A., and Retana, J., 2007, Post-fire regeneration of Mediterranean plant communities at a regional scale is dependent on vegetation type and dryness: Journal of Vegetation Science, v. 18, p. 111-122.

Barbour, M.G., Burk, J.H., Pitts, W.D., Gilliam, F.S., and Schwartz, M.W., 1999, Terrestrial plant ecology (3rd ed.): San Francisco, Benjamin Cummings.

Bahre, C.J., 1991, A legacy of change-Historic human impact on vegetation of the Arizona borderlands: Tucson, The University of Arizona Press, $231 \mathrm{p}$.

Bates, D., Maechler, M., Bolker, B., and Walker, S., 2014, lme4-Linear mixed-effects models using Eigen and S4-R package version 1.1-7: http://cran.r-project.org/web/packages/lme4/index.html

Belyea, L.R., and Lancaster, J., 1999, Assembly rules within a contingent ecology: Oikos, v. 86, p. $402-416$.

Bond, W.J., and Keeley, J.E., 2005, Fire as a global 'herbivore'-The ecology and evolution of flammable ecosystems: Trends in Ecology and Evolution, v. 20, p. 387-394.

Bond, W.J., and van Wilgen, B.W., 1996, Fire and plants: London, Chapman and Hall.

Brooks, M.L., 2000, Bromus madritensis ssp. rubens (L.) Husnot, in Invasive plants of California's wildlands: Bossard, C.C., Randall, J.M., and Hoshovsky, M.C., eds.: Berkeley, University of California Press, p. 72-75.

Brooks, M.L., 2012, Effects of high fire frequency in creosote bush scrub vegetation of the Mojave Desert: International Journal of Wildland Fire, v. 21, p. 61-68.

Brooks, M.L., D’Antonio, C.M., Richardson, D.M., Grace, J.B., Keeley, J.E., DiTomaso, J.M., Hobbs, R.J., Pellant, M., and Pyke, D., 2004, Effects of invasive alien plants on fire regimes: BioScience, V. 54, p. 677-688.

Brooks, M.L., and Esque, T.C., 2002, Alien annual plants and wildfire in desert tortoise habitat-Status, ecological effects, and management: Chelonian Conservation and Biology, v. 4, p. 330-340.

Brooks, M.L., and Matchett, J.R., 2003, Plant community patterns in unburned and burned blackbrush (Coleogyne ramosissima torr.) shrublands in the Mojave Desert: Western North American Naturalist, v. 63, p. 283-298.

Brooks, M.L., and Matchett, J.R., 2006, Spatial and temporal patterns of wildfires in the Mojave Desert, 1980-2004. Journal of Arid Environments, v. 67, p. 148-164.

Brooks, M.L., and Minnich, R.A., 2006, Fire in the southeastern deserts bioregion, in Sugihara, N.G., van Wagtendonk, J.W., Fites-Kaufman, J., Shaffer, K.E., and Thode, A.E., eds., Fire in California's ecosystems: Los Angeles, University of California Press, p. 391-414. 
Brown, D.E., and Minnich, R.A., 1986, Fire and changes in creosote bush scrub of the western Sonoran Desert, California: American Midland Naturalist, v. 116, p. 411-422

Butterfield, B.J., Betancourt, J.L., Turner, R.M., and Briggs, J.M., 2010, Facilitation drives 65 years of vegetation change in the Sonoran Desert: Ecology, v. 91, p. 1,132-1,139.

Callison, J., Brotherson, J.D., and Bowns, J.E., 1985, The effects of fire on the blackbrush (Coleogyne ramosissima) community of southwestern Utah: Journal of Range Management, v. 38, p. 535-538.

Cave, C.H., and Patten, D.T., 1984, Short-term vegetation responses to fire in the upper Sonoran Desert: Journal of Range Management, v. 37, p. 491-496.

Clarke, P.J., Knox, K.J.E., Bradstock, R.A., Munoz-Robles, C., and Kumar, L., 2014, Vegetation, terrain, and fire history shape the impact of extreme weather on fire severity and ecosystem response: Journal of Vegetation Science, v. 25, p. 1,033-1,044.

Clarke, P.J., Knox, K.J.E., Wills, K.E., and Campbell, M., 2005, Landscape patterns of woody plant response to crown fire-Disturbance and productivity influence sprouting ability: Journal of Ecology, v. 93, p. 544-555.

Cody, M.L., 2000, Slow-motion population dynamics in Mojave Desert perennial plants: Journal of Vegetation Science, v. 11, p. 351-358.

Daly, C., Halbleib, M., Smith, J.I., Gibson, W.P., Doggett, M.K., Taylor, G.H., Curtis, J., and Pasteris, P.P., 2008, Physiographically sensitive mapping of climatological temperature and precipitation across the conterminous United States: International Journal of Climatology, v. 28, p. 2,031-2,064.

D’Antonio, C.M., and Vitousek, P.M., 1992, Biological invasions by exotic grasses, the grass/fire cycle, and global change: Annual Review of Ecology and Systematics, v. 23, p. 63-87.

Davies, G.M., Bakker, J.D., Dettweiler-Robinson, E., Dunwiddie, P.W., Hall, S.A., Downs, J., and Evans, J., 2012, Trajectories of change in sagebrush steppe vegetation communities in relation to multiple wildfires: Ecological Applications, v. 22, p. 1,562-1,577.

DeFalco, L.A., Bryla, D.R., Smith-Longozo, V., and Nowak, R.S., 2003, Are Mojave Desert annual species equal?-Resource acquisition and allocation for the invasive grass Bromus madritensis ssp. rubens (Poaceae) and two native species: American Journal of Botany, v. 90, p.1,045-1,053.

DeFalco, L.A., Esque, T.C., Scoles-Sciulla, S.J., and Rodgers, J., 2010, Desert wildfire and severe drought diminish survivorship of the long-lived Joshua tree (Yucca brevifolia; Agavaceae): American Journal of Botany, v. 97, p. 243-350.

Diouf, A., Barbier, N., Lykke, A.M., Couteron, P., Deblauwe, V., Mahamane, A., Saadou, M., and Bogaert, J., 2012, Relationships between fire history, edaphic factors, and woody vegetation structure and composition in a semi-arid savanna landscape (Niger, West Africa): Applied Vegetation Science, v. 15 , p. $488-500$.

Dolédec, S., Chessel, D., and Gimaret-Carpentier, C., 2000, Niche separation in community analysisA new method: Ecology, v. 81, p. 2,914-2,927.

Drake, K.K., Esque, T.C., Nussear, K.E., DeFalco, L.A., Scoles-Sciulla, S., Modlin, A.T., and Medica, P.A., in press, Desert tortoise (Gopherus agassizii) use of burned habitat in the eastern Mojave Desert: Journal of Wildlife Management.

Dufrêne, M., and Legendre, P., 1997, Species assemblages and indicator species-The need for a flexible asymmetrical approach: Ecological Monographs, v. 67, p. 345-366.

Engel, C.E., and Abella. S.R., 2011, Vegetation recovery in a desert landscape after wildfiresInfluences of community type, time since fire and contingency effects: Journal of Applied Ecology, v. 48 , p. $1,401-1,410$.

Esque, T.C., 1994, Diet and diet selection of the desert tortoise (Gopherus agassizii) in the northeast Mojave Desert: Fort Collins, Colorado State University, Master's thesis. 
Esque, T.C., Drake, K.K., and Nussear, K.E., 2014, Water and food acquisition and their consequences on life history and metabolism of North American tortoises, chap. 10 of Rostal, D., McCoy, E.D., and Mushinsky, H., eds., Ecology of North American tortoises: Baltimore, Johns Hopkins University Press, p. 85-95.

Esque, T.C., Kaye, J.P., Eckert, S.E., DeFalco, L.A., and Tracy, C.R., 2010b, Short-term soil inorganic $\mathrm{N}$ pulse after experimental fire alters invasive and native annual plant production in a Mojave Desert shrubland: Oecologia, v. 164, p. 253-263.

Esque, T.C., and Schwalbe, C.R., 2002, Alien annual plants and their relationships to fire and biotic change in Sonoran Desert scrub, in Tellman, B., ed., Invasive exotic species in the Sonoran region: Tucson, Arizona-Sonora Desert Museum and The University of Arizona Press, p. 165-194.

Esque, T.C., Schwalbe, C.R., DeFalco, L.A., Hughes, T.J., and Duncan, R.B., 2003, Effects of wildfire on small desert vertebrates, especially desert tortoises (Gopherus agassizii): The Southwestern Naturalist, v. 48, p. 103-110.

Esque, T.C., Schwalbe, C.R., Haines, D.F., and Halvorson, W.L., 2004, Saguaros under siege-Invasive species and fire: Desert Plants, v. 20, p. 49-55.

Esque, T.C., Schwalbe, C.R., Lissow, J.A., Haines, D.F., Foster, D., and Garnett, M., 2006, Buffelgrass fuel loads in Saguaro National Park, Arizona, increase fire danger and threaten native species: Park Science, v. 24, no. 2, p. 33-37,www2.nature.nps.gov/ParkScience/.

Esque, T.C., Webb, R.H., Wallace, C.S.A., van Riper III, C., McCreedy, C., and Smythe, L., 2013, Desert fires fueled by native annual forbs - Effects of fire on communities of plants and birds in the lower Sonoran Desert of Arizona: The Southwestern Naturalist, v. 58, p. 223-233.

Esque, T.C., Young, J.A., and Tracy, C.R., 2010a, Short-term effects of experimental fires on a Mojave Desert seed bank: Journal of Arid Environments, v. 74, no. 10, p.1, 302-1,308.

Fox, J., 2003, Effect displays in R for generalized linear models: Journal of Statistical Software, v. 8, p. $1-27$.

Franco, A.C., and Nobel, P.S., 1988, Interactions between seedlings of Agave deserti and the nurse plant Hilaria rigida: Ecology, v. 69, p. 1,731-1,740.

Germano, D.J., Bury, R.B., Esque, T.C., Fritts, T.H., and Medica, P.A., 1994, Range and habitats of the desert tortoise, in, Bury, R.B., and Germano, D.J., eds., Biology of North American tortoises:

National Biological Survey, Fish and Wildlife Research 13, p. 73-84.

Godínez-Alvarez, H., Valverde, T., and Ortega-Baes, P., 2003, Demographic trends in the Cactaceae: Botanical Review, v. 69, p.173-203.

Goldberg, D.E., and Turner, R.M., 1986, Vegetation change and plant demography in permanent plots in the Sonoran Desert: Ecology, v. 67, p. 695-712.

Grace, J.B., and Keeley, J.E., 2006, A structural equation model analysis of postfire plant diversity in California shrublands: Ecological Applications, v. 16, p. 503-514.

Grime, J.P., 2006, Trait convergence and trait divergence in herbaceous plant communitiesMechanisms and consequences: Journal of Vegetation Science, v. 17, p. 255-260.

Grueber C.E., Nakagawa S., Laws R.J., and Jamieson I.G., 2011, Multimodel inference in ecology and evolution-Challenges and solutions: Journal of Evolutionary Biology, v. 24, p. 699-711.

Hansen, R.M., Johnson, M.K., and Van Devender, T.R., 1976, Foods of the desert tortoise, Gopherus agassizii, in Arizona and Utah: Herpetologica, v. 32, p. 247-251.

Harvey, B.J., and Holzman, B.A., 2014, Divergent successional pathways of stand development following fire in a California closed-cone pine forest: Journal of Vegetation Science, v. 25, p. 88-99. 
Hazard, L.C., Shemanski, D.R, and Nagy, K.A., 2010, Nutritional quality of natural foods of juvenile and adult desert tortoises (Gopherus agassizii) - Calcium, phosphorus, and magnesium digestibility: Journal of Herpetology, v. 44, p. 135-147.

Hereford, R., Webb, R.H., and Longpre, C., 2006, Precipitation history and ecosystem response to multidecadal precipitation variability in the Mojave Desert region, 1893-2001: Journal of Arid Environments, v. 67, p. 13-34.

Hillard, S., 1996, The importance of the thermal environment to juvenile desert tortoises: Fort Collins, Colorado State University, Master's thesis.

Holland, J.N., and Molina-Freaner, F., 2013, Hierarchical effects of rainfall, nurse plants, granivory and seed banks on cactus recruitment: Journal of Vegetation Science, v. 24, p. 1,053-1,061.

Jennings, W.B., 2002, Diet selection by the desert tortoise in relation to the flowering phenology of ephemeral plants: Chelonian Conservation Biology, v. 4, p. 353-358.

Jennings, W.B., and Berry, K.H., 2015, Desert tortoises (Gopherus agassizii) are selective herbivores that track the flowering phenology of their preferred food plants: PLoS ONE, v. 10, no. 1, e0116716, doi:10.1371/journal.pone.0116716.

Keddy, P.A., 1992, Assembly and response rules-Two goals for predictive community ecology: Journal of Vegetation Science, v. 3, p. 157-164.

Keeley, J.E., Fotheringham, C.J., and Baer-Keeley, M., 2005, Determinants of postfire recovery and succession in Mediterranean-climate shrublands of California: Ecological Applications, v. 15, p. $1,515-1,534$.

Keeley, J.E., Fotheringham, C.J., and Baer-Keeley, M., 2006, Demographic patterns of postfire regeneration in Mediterranean-climate shrublands of California: Ecological Monographs, v. 76, p. 235-255.

Key, C.H., and Benson, N.C., 2005, Landscape assessment: remote sensing of severity, the Normalized Burn Ratio, in Lutes, D.C., Keane, R.E., Caratti, J.F., Key, C.H., Benson, N.C., and Gangi, L.J., eds., FIREMON_-Fire effects monitoring and inventory system: U.S. Forest Service [RMRS-GTR-164], Ogden, Utah.

Levick, S.R., Asner, G.P., and Smit, I.P.J., 2012, Spatial patterns in the effects of fire on savanna vegetation three-dimensional structure: Ecological Applications, v. 22, p. 2,110-2,121.

Lovich, J.E., Ennen, J.R. Madrak, S.V., Loughran, C.L., Meyer, K.P., Arundel, T.R., and Bjurlin, C.D., 2011, Long-term post-fire effects on spatial ecology and reproductive output of female Agassiz's desert tortoises (Gopherus agassizii) at a wind energy facility near Palm Springs, California, USA: Fire Ecology, v. 7, p. 75-85.

MacMahon, J.A., 2000, Warm deserts, in Barbour, M.G., and Billings, W.D., eds., North American terrestrial vegetation: Cambridge, United Kingdom, Cambridge University Press, p. 285-322.

Mason, N.W.H., Wilson, J.B., and Steel, J.B., 2007, Are alternative stable states more likely in high stress environments?-Logic and available evidence do not support Didham and others, 2005: Oikos, v. 116 , p. 353-357.

Mazerolle, M.J., 2013, AICcmodavg-Model selection and multimodel inference based on (Q)AIC(c) - R package version 1.35: The Comprehensive R Archive Network Web site, accessed [July 18th, 2014], at http://CRAN.R-project.org/package=AICcmodavg.

McAuliffe, J.R., 1986, Herbivore-limited establishment of a Sonoran Desert tree, Cercidium microphyllum: Ecology, v. 67, p. 276-280.

McAuliffe, J.R., 1988, Markovian dynamics of simple and complex desert plant communities: The American Naturalist, v. 131, p. 459-490. 
McAuliffe, J.R., 1995, The aftermath of wildfire in the Sonoran Desert: Sonoran Quarterly, v. 49, p. 4 8.

McLaughlin, S.P., and Bowers, J.E. ,1982, Effects of wildfire on a Sonoran Desert plant community: Ecology, v. 63,p. 246-248.

Medeiros, A.S., and Drezner, T.D., 2012, Vegetation, climate, and soil relationships across the Sonoran Desert: Ecoscience, v. 19, p. 148-160.

Medica, P.A., and Eckert, S.E., 2007, Gopherus agassizii, desert tortoise-Food/mechanical injuryNatural history notes: Herpetological Review, v. 38, p. 446-448.

Minnich, R.A., 1995, Wildland fire and early postfire succession in Joshua tree woodland and blackbrush scrub of the Mojave Desert of California: San Bernardino County Museum Association Quarterly, v. 4, p. 99-106.

Morafka, D.J., Spangenberg, E.K., and Lance, V.A., 2000, Neontology of reptiles: Herpetological Monographs, v. 14, p. 353-370.

Moretti, M., and Legg, C., 2009, Combining plant and animal traits to assess community functional responses to disturbance: Ecography, v. 32, p. 299-309.

Munson, S.M., Webb, R.H., Belnap, J., Hubbard, J.A., Swann, D.E., and Rutman, S., 2012, Forecasting climate change impacts to plant community composition in the Sonoran Desert region: Global Change Biology, v. 18, p. 1,083-1,095.

Nagy, K.A., Henen, B.T., and Vyas, D.B., 1998, Nutritional quality of native and introduced food plants of wild desert tortoises: Journal of Herpetology, v. 32, p. 260-267.

Nakagawa, S., and Schielzeth, H., 2013, A general and simple method for obtaining $R^{2}$ from generalized linear mixed-effect models: Methods in Ecology and Evolution, v. 4, p. 133-142.

Nano, C.E., and Clarke, P.J., 2011, How do drought and fire influence the patterns of resprouting in Australian deserts?: Plant Ecology, v. 212, p. 2,095-2,110.

Nussear, K.E., 2004, Mechanistic investigation of the distributional limits of the desert tortoise Gopherus agassizii: Reno, University of Nevada, Ph.D. thesis.

Nussear, K.E., and Tuberville, T.D., 2014, Habitat characteristics of North American tortoises, in Rostal, D.C., McCoy, E.D., and Mushinsky, H.R., eds., Biology and conservation of North American tortoises: Baltimore, Johns Hopkins University Press, p 77-85.

Oksanen, J., Guillaume Blanchet, F., Kindt, R., Legendre, P., Minchin, P.R., O'Hara, R.B., Simpson, G.L., Solymos, P., Stevens, M.H.H., and Wagner, H., 2013, vegan — Community ecology package-R package version 2.0-10: The Comprehensive R Archive Network Web site, accessed [May 16th, 2014], at http://CRAN.R-project.org/package=vegan

Parker, K.C., 1991, Topography, substrate, and vegetation patterns in the northern Sonoran Desert: Journal of Biogeography, v. 18, p. 151-163.

Pausas, J.G., and Bradstock, R.A., 2007, Fire persistence traits of plants along a productivity and disturbance gradient in Mediterranean shrublands of south-east Australia: Global Ecology and Biogeography, v. 16, p. 330-340.

Pausas, J.G., Bradstock, R.A., Keith, D.A., Keeley, J.E., and GCTE Fire Network, 2004, Plant functional traits in relation to fire in crown-fire ecosystems: Ecology , v. 85, p. 1,085-1,100.

Pausas, J.G., and Verdu, M., 2008, Fire reduces morphospace occupation in plant communities: Ecology, v. 89, p. 2,181-2,186.

Reynolds, M.B.J., DeFalco, L.A., and Esque, T.C., 2012, Short seed longevity, variable germination conditions, and infrequent establishment events provide a narrow window for Yucca brevifolia (Agavaceae) recruitment: American Journal of Botany, v. 99, p. 1,647-1,654. 
Richards, S.A., 2008, Dealing with overdispersed count data in applied ecology: Journal of Applied Ecology, v. 45, p. 218-227.

Rogers, G.F., and Steele, J., 1980, Sonoran Desert fire ecology: U.S. Forest Service [RM-GTR-81], Fort Collins, Colorado.

Rogers, G.F., and Vint, M.K., 1987, Winter precipitation and fire in the Sonoran Desert: Journal of Arid Environments, v. 13, p. 47-52.

Salo, L.F., 2004, Population dynamics of red brome (Bromus madritensis subsp. rubens)—Times for concern, opportunities for management: Journal of Arid Environments, v. 57, p. 291-296.

Schmid, M.K., and Rogers, G.F., 1988, Trends in fire occurrence in the Arizona upland subdivision of the Sonoran Desert, 1955-1983: The Southwestern Naturalist, v. 33, p. 437-444.

Schröder, A., Persson, L., and De Roos, A.M., 2005, Direct experimental evidence for alternative stable states-A review: Oikos, v. 110. p. 3-19.

Shryock, D.F., DeFalco, L.A., and Esque, T.C., 2014, Life-history traits predict perennial species response to fire in a desert ecosystem: Ecology and Evolution, v. 4, p. 3,046-3,059.

Smart, S.M., Thompson, K., Marrs, R.H., Le Duc, M.G., Maskell, L.C., and Firbank, L.G., 2006, Biotic homogenization and changes in species diversity across human-modified ecosystems: Proceedings of the Royal Society, v. B 273, p. 2,659-2,665.

Snyder, S.J., 2014, Effects of fire on desert tortoise (Gopherus agassizii) thermal ecology: Reno, University of Nevada, Ph.D. thesis, 164 p.

Soulard, C.E., Esque, T.C., Bedford, D.R., and Bond, S., 2013, The role of fire on soil mounds and surface roughness in the Mojave Desert: Earth Surface Processes and Landforms, v. 38, p. 111-121, doi:10.1002/esp.3264.

Steers, R.J., and Allen, E.B., 2011, Fire effects on perennial vegetation of the western Colorado Desert, USA: Fire Ecology, v. 7, p. 59-74.

Swantek, P.J., Halvorson, W.L., and Schwalbe, C.R., 1999, GIS database development to analyze fire history in southern Arizona and beyond-An example from Saguaro National Park: Tucson, University of Arizona, School of Renewable and Natural Resources, U.S. Geological Survey Cooperative Studies Unit, Technical Report 61.

Tielbörger, K., and Kadmon, R., 2000, Temporal environmental variation tips the balance between facilitation and interference in desert plants: Ecology, v. 81, p. 1,544-1,553.

Turner, R.M., and Brown, D.E., 1994, Sonoran Desertscrub, in Brown, D.E., ed.: Biotic communitiesSouthwestern United States and northwestern Mexico (2nd ed.): Salt Lake City, University of Utah Press, p. 181-222.

Turner, R.M., Webb, R.H., Esque, T.C., and Rogers, G.F., 2010, Repeat photography and low-elevation fire responses in the southwestern United States, chap. 17 of Webb, R.H., Boyer, D.E., and Turner, R.M., eds., Repeat photography-Methods and applications in the Natural Sciences: Washington, D.C., Island Press, p. 223-244.

Vamstad, M.S., and Rotenberry, J.T,. 2010, Effects of fire on vegetation and small mammal communities in a Mojave Desert Joshua tree woodland: Journal of Arid Environments, v. 74, p. 1,309-1,318.

van den Brink, P.J., and ter Braak, C.J.F., 1998, Multivariate analysis of stress in experimental ecosystems by principal response curves and similarity analysis: Aquatic Ecology, v. 32, p. 163-178. van den Brink, P.J., and ter Braak, C.J.F., 1999, Principal response curves-Analysis of time-dependent multivariate response of biological community to stress: Environmental Toxicology and Chemistry, v. 18 , p. 138-148. 
Van Devender, T.R. 2002. Natural history of the Sonoran tortoise in Arizona-Life in a rock pile, in The Sonoran Desert tortoise - Natural history, biology, and conservation, Van Devender, T.R., ed.: Tucson, The University of Arizona Press and the Arizona-Sonora Desert Museum, p. 3-28.

Van Devender, T.R., Averill-Murray, R.C., Esque, T.C., Holm, P.A., Dickinson, V.M., Schwalbe, C.R., Wirt, E.B., and Barrett, S.L., 2002, Grasses, mallows, desert vine, and more-Diet of the desert tortoise in Arizona and Sonora, in Van Devender, T.R., ed., The Sonoran Desert tortoise-Natural history, biology, and conservation: Tucson, The University of Arizona Press and the Arizona-Sonora Desert Museum, p. 159-193.

Wilson, R.C., Narog, M.G., Koonce, A.L., and Corcoran, B.M., 1995, Postfire regeneration in Arizona's giant saguaro shrub community: U.S. Forest Service [RM-GTR-264], Fort Collins, Colorado.

\section{Products Resulting From This Cooperative Effort}

Esque, T.C., Shryock, D.F., Nussear, K.E., and Inman R.D., 2014, A 30-year chronosequence of fires in Sonoran tortoise habitat, and results of nutrition experiments. Workshop of Sonoran Desert Tortoise experts in consideration of the Federal listing of the tortoise under the Endangered Species Act at Arizona Game and Fish Department (AGDF), with representation from AGFD, U.S. Fish and Wildlife Service, Bureau of Land Management, National Park Service, and private industry, June 21, 2014. Esque, T.C., Shryock, D.F., Nussear, K.E., Berger, A.J., Chen, F.C., Drake, K.K., and Inman, R.D., 2015, What drives vegetation change after fires, and why is that change important to Sonoran Desert Tortoises?: 40th Annual Desert Tortoise Council Symposium, February 19-21, 2015, Las Vegas, Nevada. 


\section{Appendix A. Model Averaged Coefficients}

Standardized model-averaged coefficients for terms in the candidate model sets presented in tables 5 and 6.

Table A1. Standardized model-averaged coefficients from candidate model sets $(\Delta \mathrm{AlC} c<4)$ showing the relative influence of different parameters on percentage cover of perennial growth forms sampled following fire in the Sonoran Desert.

[Coefficients are displayed as treatment contrasts. SE, standard error; NA, term not in candidate model set]

\begin{tabular}{|c|c|c|c|c|c|c|c|c|c|c|c|c|}
\hline \multirow[b]{2}{*}{ Term / Factor level } & \multicolumn{2}{|c|}{ Tree } & \multicolumn{2}{|c|}{ Shrub } & \multicolumn{2}{|c|}{ Subshrub } & \multicolumn{2}{|c|}{ Grass } & \multicolumn{2}{|c|}{ Forb } & \multicolumn{2}{|c|}{ Cactus } \\
\hline & $\begin{array}{c}\text { Model- } \\
\text { averaged } \\
\text { coefficient }\end{array}$ & SE & $\begin{array}{c}\text { Model- } \\
\text { averaged } \\
\text { coefficient }\end{array}$ & SE & $\begin{array}{c}\text { Model- } \\
\text { averaged } \\
\text { coefficient }\end{array}$ & SE & $\begin{array}{c}\text { Model- } \\
\text { averaged } \\
\text { coefficient }\end{array}$ & SE & $\begin{array}{c}\text { Model- } \\
\text { averaged } \\
\text { coefficient }\end{array}$ & SE & $\begin{array}{c}\text { Model- } \\
\text { averaged } \\
\text { coefficient }\end{array}$ & SE \\
\hline Unburned & 0.192 & 0.067 & 0.005 & 0.257 & 0.038 & 0.198 & 0.808 & 0.295 & -0.135 & 0.332 & 0.568 & 0.149 \\
\hline Elevation & NA & NA & 0.125 & 0.105 & 0.048 & 0.096 & 0.743 & 0.101 & 0.551 & 0.154 & -0.081 & 0.139 \\
\hline Ann.Prcp & NA & NA & 0.385 & 0.114 & 0.305 & 0.113 & NA & NA & NA & NA & 0.178 & 0.171 \\
\hline Slope & NA & NA & NA & NA & 0.247 & 0.111 & NA & NA & NA & NA & -0.072 & 0.083 \\
\hline Asp.N & -0.148 & 0.096 & -0.086 & 0.109 & 0.311 & 0.111 & 0.136 & 0.08 & 0.098 & 0.102 & -0.006 & 0.029 \\
\hline Burned: $1990 \mathrm{~s}^{1}$ & NA & NA & NA & NA & NA & NA & NA & NA & -0.528 & 0.155 & -0.026 & 0.206 \\
\hline Unburned: $1990 \mathrm{~s}$ & NA & NA & NA & NA & NA & NA & NA & NA & -0.086 & 0.149 & -0.472 & 0.204 \\
\hline Burned: 1980s & NA & NA & NA & NA & NA & NA & NA & NA & -0.44 & 0.163 & 0.316 & 0.187 \\
\hline Unburned: 1980s & NA & NA & NA & NA & NA & NA & NA & NA & -0.198 & 0.161 & -0.148 & 0.180 \\
\hline Unburned: Elevation & NA & NA & 0.037 & 0.134 & NA & NA & -0.997 & 0.3 & -0.367 & 0.413 & NA & NA \\
\hline Unburned: Ann.Prcp & NA & NA & 0.275 & 0.272 & NA & NA & NA & NA & NA & NA & NA & NA \\
\hline Unburned: Slope & NA & NA & NA & NA & -0.182 & 0.218 & NA & NA & NA & NA & NA & NA \\
\hline Unburned: Asp.N & NA & NA & 0.070 & 0.095 & -0.108 & 0.117 & NA & NA & -0.023 & 0.066 & NA & NA \\
\hline
\end{tabular}

${ }^{1}$ Coefficients for interaction terms show departure from the reference category. Reference categories: Burned: 2000s; Unburned: 2000s; Burned: Elevation; Burned: Ann.Prcp; Burned: Slope; Burned: Asp.N. 
Table A2. Standardized model-averaged coefficients from candidate model sets $(\triangle \mathrm{AIC}<4$ ) showing the relative influence of different parameters on vegetation percentage cover, average vegetation height, and vegetation density.

[Coefficients are displayed as treatment contrasts. SE, standard error; NA, term not in candidate model set]

\begin{tabular}{l|cc|cc|cc}
\hline \multirow{2}{*}{ Term / Factor level } & \multicolumn{2}{c|}{ Cover } & \multicolumn{2}{c|}{ Density } & \multicolumn{2}{c}{ Height } \\
\cline { 2 - 7 } & $\begin{array}{c}\text { Model- } \\
\text { averaged } \\
\text { coefficient }\end{array}$ & SE & $\begin{array}{c}\text { Model- } \\
\text { averaged } \\
\text { coefficient }\end{array}$ & SE & $\begin{array}{c}\text { Model- } \\
\text { averaged } \\
\text { coefficient }\end{array}$ & SE \\
\hline Unburned & 0.211 & 0.048 & -0.391 & 0.206 & 1.508 & 0.255 \\
Elevation & 0.468 & 0.096 & 0.522 & 0.143 & -0.061 & 0.142 \\
Ann.Prcp & 0.375 & 0.093 & -0.022 & 0.090 & 0.185 & 0.158 \\
Slope & 0.052 & 0.064 & NA & NA & 0.022 & 0.060 \\
Asp.N & NA & NA & 0.035 & 0.061 & -0.060 & 0.083 \\
Burned: $1990 \mathrm{~s}{ }^{1}$ & NA & NA & -0.245 & 0.240 & 0.083 & 0.190 \\
Unburned: $1990 \mathrm{~s}$ & NA & NA & -0.178 & 0.189 & 0.027 & 0.089 \\
Burned: $1980 \mathrm{~s}$ & NA & NA & -0.182 & 0.196 & 0.081 & 0.186 \\
Unburned: $1980 \mathrm{~s}$ & NA & NA & -0.049 & 0.120 & 0.031 & 0.094 \\
Unburned: Ann.Prcp & NA & NA & 0.128 & 0.237 & -1.014 & 0.224 \\
Unburned: Slope & NA & NA & NA & NA & -0.123 & 0.175 \\
Unburned: Asp.N & NA & NA & NA & NA & -0.024 & 0.064 \\
\hline
\end{tabular}

${ }^{1}$ Coefficients for interaction terms show departure from the reference category. Reference categories: Burned: 2000s; Unburned: 2000s; Burned: Elevation; Burned: Ann.Prcp; Burned: Slope; Burned: Asp.N. 


\section{Appendix B. Sonoran Desert Tortoise Food and Cover Plants}

Table B1. Sonoran Desert Tortoise food plants (Van Devender and others, 2002) observed on burned and unburned cover transects at 13 fires in the Arizona Upland subdivision of the Sonoran Desert, Arizona, 2013.

[Plants are ranked by expert opinion according to their value as cover for Sonoran Desert Tortoises on a scale from 0 to 3 (3 being greatest value). For each species, the number of occurrences across the 13 fires is summed and categorized according to whether the occurrence was on a burned or unburned transect]

\begin{tabular}{|c|c|c|c|c|c|}
\hline Species & Code & Growth form & $\begin{array}{l}\text { Expert opinion } \\
\text { cover values }\end{array}$ & $\begin{array}{c}\text { Number of } \\
\text { burned } \\
\text { sites }\end{array}$ & $\begin{array}{c}\text { Number of } \\
\text { unburned } \\
\text { sites }\end{array}$ \\
\hline Adenophyllum porophylloides & $\mathrm{ADPO}$ & Subshrub & 1 & 10 & 5 \\
\hline Ambrosia deltoidea & AMDE & Shrub & 3 & 5 & 4 \\
\hline Ambrosia dumosa & AMDU & Shrub & 3 & 2 & 2 \\
\hline Ayenia sp. (filiformis) & Ayenia & Subshrub (f) & 0 & 4 & 3 \\
\hline Bouteloua curtipendula & BOCU & Grass & 1 & 4 & 4 \\
\hline Calliandra eriophylla & CAER & Shrub & 2 & 9 & 8 \\
\hline Chamaesyce sp. & Cham & Forb & 0 & 8 & 6 \\
\hline Cirsium neomexicanum & CINE & Forb & 1 & 1 & 1 \\
\hline Ditaxis lanceolata & DILA & Forb & 0 & 3 & 4 \\
\hline Eriogonum fasciculatum & ERFA & Shrub & 1 & 8 & 10 \\
\hline Fagonia laevis & FALA & Subshrub & 1 & 1 & 1 \\
\hline Galium stellatum & GAST & Shrub & 1 & 5 & 5 \\
\hline Krameria erecta & KRER & Shrub & 1 & 9 & 8 \\
\hline Krameria sp. & Krameria & Shrub & 1 & 2 & 1 \\
\hline Lotus rigidus & LORI & Forb & 2 & 7 & 4 \\
\hline Lycium berlandieri & LYBE & Shrub & 2 & 4 & 2 \\
\hline Lycium sp. & Lycium & Shrub & 2 & 7 & 7 \\
\hline Opuntia engelmannii & OPEN & Cactus & 3 & 2 & 5 \\
\hline Parkinsonia microphylla & PAMI & Tree & 3 & 11 & 11 \\
\hline Pleuraphis rigida & PLRI & Grass & 2 & 6 & 7 \\
\hline Porophyllum gracile & POGR & Subshrub & 1 & 7 & 5 \\
\hline Simmondsia chinensis & $\mathrm{SICH}$ & Shrub & 3 & 6 & 6 \\
\hline Sphaeralcea ambigua & SPAM & Forb & 2 & 12 & 8 \\
\hline Tridens muticus & TRMU & Grass & 1 & 5 & 4 \\
\hline Viguiera parishii & VIPA & Shrub & 2 & 6 & 7 \\
\hline
\end{tabular}


Table B2. Perennial plant taxa sampled on burned and unburned cover transects at 13 fires in the Arizona Upland subdivision of the Sonoran Desert, Arizona, 2013.

[These species are believed to have value as cover for Sonoran Desert Tortoises based on expert opinion, but were not listed as food species by Van Devender and others (2002)]

\begin{tabular}{|c|c|c|c|c|c|}
\hline Species & Code & $\begin{array}{c}\text { Growth } \\
\text { form }\end{array}$ & $\begin{array}{c}\text { Expert opinion } \\
\text { cover values }\end{array}$ & $\begin{array}{c}\text { Number of } \\
\text { burned } \\
\text { sites }\end{array}$ & $\begin{array}{c}\text { Number of } \\
\text { unburned } \\
\text { sites }\end{array}$ \\
\hline Acacia constricta & $\mathrm{ACCO}$ & Shrub & 1 & 2 & 2 \\
\hline Acacia greggii & ACGR & Shrub & 2 & 11 & 9 \\
\hline Acamptopappus sphaerocephalus & ACSP & Shrub & 1 & 0 & 2 \\
\hline Achnatherum speciosum & ACHSPE & Grass & 1 & 3 & 5 \\
\hline Agave sp. & Agave & Succulent & 2 & 2 & 1 \\
\hline Aloysia wrightii & ALWR & Shrub & 2 & 2 & 1 \\
\hline Aristida purpurea & ARPU & Grass & 1 & 9 & 5 \\
\hline Artemisia ludoviciana & ARLU & Forb & 1 & 2 & 2 \\
\hline Baileya multiradiata & BAMU & Forb & 1 & 1 & 0 \\
\hline Bebbia juncea & BEJU & Shrub & 1 & 4 & 3 \\
\hline Boechera perennans & BOPE & Forb & 1 & 1 & 3 \\
\hline Bouteloua eriopoda & BOER & Grass & 1 & 2 & 1 \\
\hline Calochortus sp. & Calochortus & Forb & 0 & 2 & 1 \\
\hline Canotia holacantha & $\mathrm{CAHO}$ & Shrub & 2 & 2 & 5 \\
\hline Carnegia gigantea & CAGI & Cactus & 1 & 2 & 1 \\
\hline Cercocarpus montanus & CEMO & Shrub & 0 & 0 & 1 \\
\hline Cheilanthes sp. & Cheilanthes & Fern & 0 & 1 & 2 \\
\hline Cottsia gracilis & COGR & Subshrub & 2 & 7 & 7 \\
\hline Crossosoma bigelovii & CRBI & Shrub & 1 & 1 & 2 \\
\hline Cylindropuntia acanthocarpa & CYAC & Cactus & 2 & 8 & 11 \\
\hline Cylindropuntia bigelovii & CYBI & Cactus & 1 & 1 & 2 \\
\hline Cylindropuntia fulgida & CYFU & Cactus & 2 & 1 & 1 \\
\hline Dalea mollis & DAMO & Subshrub & 0 & 3 & 3 \\
\hline Dichelostemma capitatum & DICA & Forb & 0 & 6 & 3 \\
\hline Ditaxis neomexicana & DINE & Forb & 0 & 2 & 3 \\
\hline Dodonaea viscosa & DOVI & Shrub & 3 & 1 & 1 \\
\hline Echinocereus engelmannii & ECEN & Cactus & 1 & 2 & 7 \\
\hline Elymus elymoides & ELEL & Grass & 1 & 0 & 1 \\
\hline Encelia farinosa & ENFA & Shrub & 2 & 11 & 11 \\
\hline Encelia frutescens & ENFR & Shrub & 2 & 2 & 3 \\
\hline Encelia virginensis & ENVI & Shrub & 2 & 2 & 3 \\
\hline Ephedra aspera & EPAS & Shrub & 3 & 1 & 1 \\
\hline Ephedra fasciculata & EPFA & Shrub & 3 & 1 & 1 \\
\hline Ephedra nevadensis & EPNE & Shrub & 3 & 3 & 4 \\
\hline Ephedra sp. & Ephedra & Shrub & 3 & 1 & 3 \\
\hline Ephedra viridis & EPVI & Shrub & 3 & 1 & 2 \\
\hline Ericameria laricifolia & ERLA & Shrub & 1 & 1 & 3 \\
\hline Ericameria linearifolia & ERLI & Shrub & 1 & 0 & 1 \\
\hline
\end{tabular}




\begin{tabular}{|c|c|c|c|c|c|}
\hline Species & Code & $\begin{array}{l}\text { Growth } \\
\text { form }\end{array}$ & $\begin{array}{l}\text { Expert opinion } \\
\text { cover values }\end{array}$ & $\begin{array}{c}\text { Number of } \\
\text { burned } \\
\text { sites }\end{array}$ & $\begin{array}{c}\text { Number of } \\
\text { unburned } \\
\text { sites }\end{array}$ \\
\hline Ericameria sp. & Ericameria & Shrub & 1 & 2 & 3 \\
\hline Eriogonum inflatum & ERIN & Forb & 0 & 4 & 5 \\
\hline Eriogonum wrightii & ERWR & Shrub & 1 & 5 & 4 \\
\hline Ferocactus cylindraceus & FECY & Cactus & 2 & 1 & 3 \\
\hline Fouquieria splendens & FOSP & Shrub & 1 & 3 & 11 \\
\hline Gutierrezia sarothrae & GUSA & Subshrub & 2 & 7 & 4 \\
\hline Hymenoclea salsola & HYSA & Shrub & 2 & 2 & 0 \\
\hline Hyptis emoryi & HYEM & Shrub & 2 & 2 & 1 \\
\hline Justicia longii & JULO & Forb & 1 & 1 & 2 \\
\hline Keckiella antirrhinoides & KEAN & Shrub & 1 & 2 & 1 \\
\hline Krameria grayi & KRGR & Shrub & 1 & 3 & 2 \\
\hline Larrea tridentata & LATR & Shrub & 3 & 5 & 7 \\
\hline Lycium exsertum & LYEX & Shrub & 2 & 2 & 2 \\
\hline Mammillaria grahamii & MAGR & Cactus & 0 & 1 & 1 \\
\hline Matelea parvifolia & MAPA & Forb & 1 & 5 & 3 \\
\hline Melampodium leucanthum & MELE & Forb & 1 & 3 & 1 \\
\hline Menodora scabra & MESC & Subshrub & 1 & 4 & 7 \\
\hline Metastelma arizonicum & MEAR & Forb & 1 & 2 & 3 \\
\hline Mirabilis laevis & MILA & Forb & 1 & 5 & 6 \\
\hline Muhlenbergia porteri & MUPO & Grass & 2 & 4 & 6 \\
\hline Nolina bigelovii & NOBI & Shrub & 3 & 1 & 1 \\
\hline Nolina microcarpa & NOMI & Shrub & 3 & 2 & 0 \\
\hline Opuntia phaeacantha & $\mathrm{OPPH}$ & Cactus & 3 & 1 & 2 \\
\hline Parkinsonia florida & PAFL & Tree & 3 & 2 & 0 \\
\hline Pellaea truncata & PETR & Fern & 1 & 2 & 0 \\
\hline Cenchrus ciliaris & CECI & Grass & 1 & 1 & 1 \\
\hline Penstemon subulatus & PESU & Forb & 1 & 0 & 2 \\
\hline Pleuraphis mutica & PLMU & Grass & 1 & 1 & 2 \\
\hline Prosopis velutina & PRVE & Tree & 3 & 1 & 2 \\
\hline Psilostrophe cooperi & PSCO & Subshrub & 1 & 2 & 2 \\
\hline Quercus turbinella & QUTU & Shrub & 3 & 2 & 1 \\
\hline Salazaria mexicana & SAME & Shrub & 2 & 3 & 2 \\
\hline Senna covesii & SECO & Forb & 1 & 8 & 2 \\
\hline Stephanomeria sp. & Steph & Subshrub & 1 & 7 & 9 \\
\hline Thamnosma montana & THMO & Shrub & 1 & 1 & 2 \\
\hline Trixis californica & TRCA & Subshrub & 2 & 1 & 2 \\
\hline Xanthisma spinulosum & XASP & Forb & 1 & 4 & 5 \\
\hline Xylorhiza tortifolia & XYTO & Subshrub & 2 & 0 & 2 \\
\hline Yucca baccata & YUBA & Shrub & 3 & 1 & 4 \\
\hline Ziziphus obtusifolia & ZIOB & Shrub & 3 & 0 & 2 \\
\hline
\end{tabular}


Table B3. Sonoran Desert perennial taxa known to be food species based on Van Devender and others (2002), but not observed on burned and unburned cover transects at 13 fires in the Arizona Upland subdivision of the Sonoran Desert, Arizona, 2013.

\begin{tabular}{lll}
\hline \multicolumn{1}{c}{ Species } & \multicolumn{1}{c}{ Code } & \multicolumn{1}{c}{ Growth form } \\
\hline Abutilon parishii & ABPA & Forb \\
Acourtia nana & ACNA & Forb \\
Acourtia wrightii & ACWR & Forb \\
Allionia incarnata & ALIN & Perennial/annual forb \\
Aristida arizonica & ARAR & Grass \\
Aristida ternipes & ARTE & Grass \\
Astragalus sp. & ASsp & Perennial/annual forb \\
Bouteloua hirsuta & BOHI & Grass \\
Bouteloua repens & BORE & Grass \\
Bouteloua rothrockii & BORO & Grass \\
Chamaesyce polycarpa & CHPO & Perennial/annual forb \\
Cynodon dactylon & CYDA & Grass \\
Digitaria californica & DICA & Grass \\
Erioneuron pulchellum & ERPU & Grass \\
Euphorbia capitellata & EUCA & Forb \\
Evolvulus alsinoides & EVAL & Forb \\
Hibiscus coulteri & HICO & Subshrub \\
Marina parryi & MAPA & Perennial/annual forb \\
Olneya tesota & OLTE & Tree \\
Hilaria berlangeri & PLBE & Grass \\
Selaginella arizonica & SEAR & Forb \\
Senna bauhinioides & SEBA & Forb \\
Setaria macrostachya & SEMA & Grass \\
Sida neomexicana & SINE & Forb \\
\hline
\end{tabular}




\section{Appendix C. Cover and Density for Perennial Plant Species}

Perennial plant species cover, principal response curves, and density averaged across fires.

Table C1. Percentage cover (plus standard error) and principal response curve (PRC) scores of perennial plant species measured on burned and unburned control transects at 13 fires in the Arizona Upland subdivision of the Sonoran Desert, Arizona.

[For each species, percentage cover values were averaged across transects from all fires for burned and unburned treatment groups, and these differences were then evaluated for statistical significance with Analysis of Variance (ANOVA). F-values are from one-way ANOVA with burn treatment (burned, unburned) and transect-level cover for each species. SE, standard error; NAs denote species measured for density but not cover]

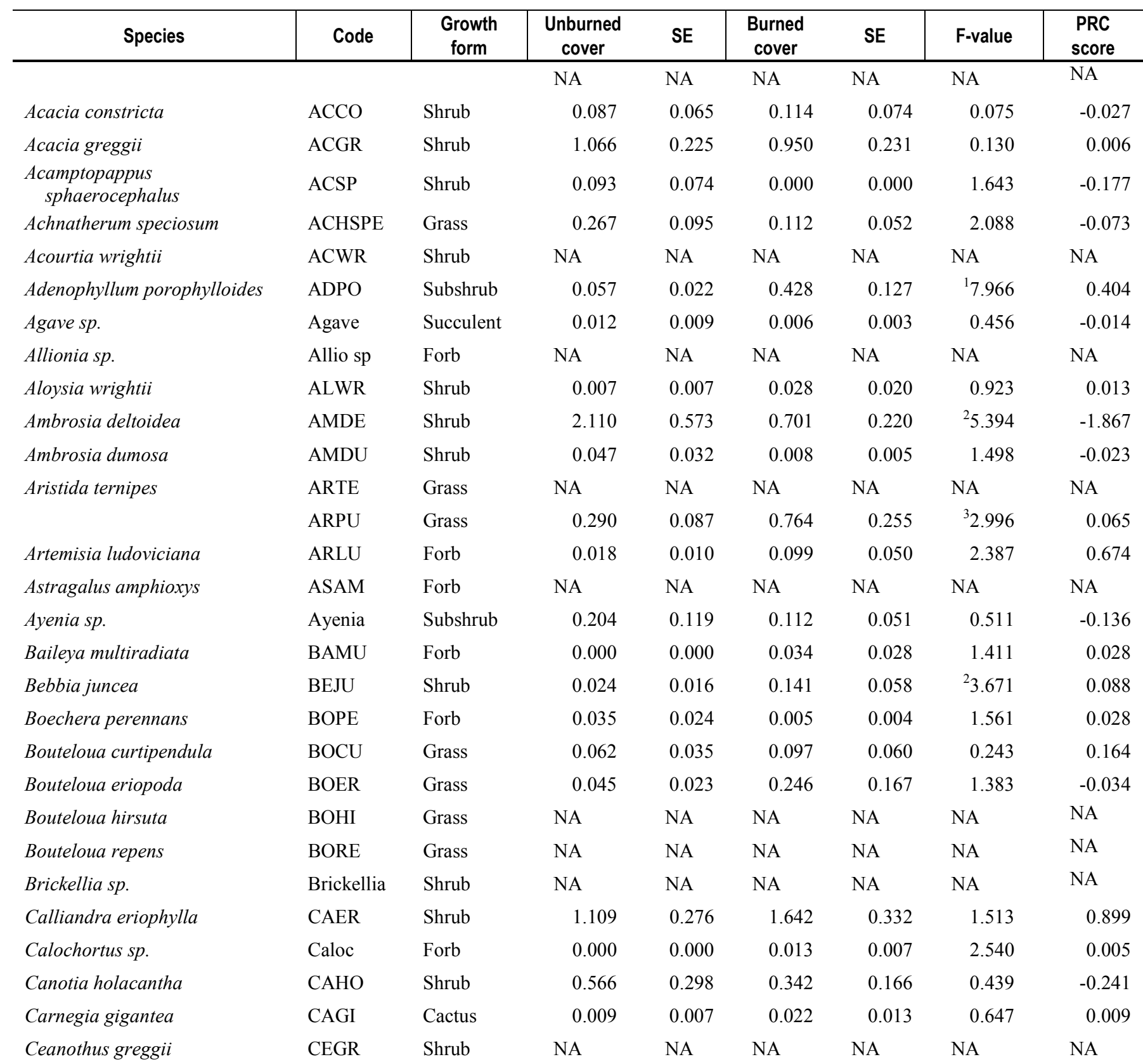









\begin{tabular}{|c|c|c|c|c|c|c|c|c|}
\hline Species & Code & $\begin{array}{l}\text { Growth } \\
\text { form }\end{array}$ & $\begin{array}{c}\text { Unburned } \\
\text { cover }\end{array}$ & SE & $\begin{array}{c}\text { Burned } \\
\text { cover }\end{array}$ & SE & F-value & $\begin{array}{l}\text { PRC } \\
\text { score }\end{array}$ \\
\hline Fouquieria splendens & FOSP & Shrub & 0.336 & 0.084 & 0.087 & 0.035 & ${ }^{1} 7.64$ & -0.273 \\
\hline Gaura sp. & Gaura.sp & Forb & NA & NA & NA & NA & NA & NA \\
\hline Gutierrezia sarothrae & GUSA & Subshrub & 0.406 & 0.119 & 0.801 & 0.250 & 1.983 & 0.533 \\
\hline Horsfordia sp. & Hors sp & Subshrub & NA & NA & NA & NA & NA & NA \\
\hline Hybanthus verticillatus & HYVE & Forb & NA & NA & NA & NA & NA & NA \\
\hline Hymenoclea salsola & HYSA & Shrub & 0.000 & 0.000 & 0.026 & 0.024 & 1.169 & 0.039 \\
\hline Hyptis emoryi & HYEM & Shrub & 0.016 & 0.011 & 0.056 & 0.042 & 0.819 & 0.017 \\
\hline Justicia longii & JULO & Forb & 0.012 & 0.009 & 0.004 & 0.003 & 0.881 & -0.016 \\
\hline Krameria grayi & KRGR & Shrub & 0.110 & 0.063 & 0.063 & 0.036 & 0.438 & 0.15 \\
\hline Krameria sp. & Krameria & Shrub & 0.050 & 0.040 & 0.050 & 0.035 & 0.000 & -0.045 \\
\hline Larrea tridentata & LATR & Shrub & 1.847 & 0.454 & 0.535 & 0.156 & ${ }^{1} 7.682$ & -1.303 \\
\hline Lotus rigidus & LORI & Forb & 0.084 & 0.038 & 0.307 & 0.112 & ${ }^{3} 3.45$ & 0.303 \\
\hline Lycium berlandieri & LYBE & Shrub & 0.008 & 0.008 & 0.118 & 0.053 & ${ }^{2} 3.995$ & 0.113 \\
\hline Lycium exsertum & LYEX & Shrub & 0.287 & 0.133 & 0.182 & 0.116 & 0.350 & -0.111 \\
\hline Lycium sp. & Lycium & Shrub & 0.245 & 0.079 & 0.276 & 0.142 & 0.037 & -0.047 \\
\hline Mammillaria grahamii & MAGR & Cactus & 0.001 & 0.001 & 0.001 & 0.001 & 0.001 & 0 \\
\hline Mammillaria sp. & Mamm sp & Cactus & NA & NA & NA & NA & NA & NA \\
\hline Muhlenbergia porteri & MUPO & Grass & 0.251 & 0.118 & 0.043 & 0.024 & ${ }^{3} 3.067$ & -0.323 \\
\hline Nolina bigelovii & NOBI & Shrub & 0.139 & 0.105 & 0.107 & 0.107 & 0.045 & -0.029 \\
\hline Nolina microcarpa & NOMI & Shrub & 0.000 & 0.000 & 0.084 & 0.066 & 1.575 & 0.086 \\
\hline Opuntia chlorotica & $\mathrm{OPCH}$ & Cactus & NA & NA & NA & NA & NA & NA \\
\hline Opuntia engelmannii & OPEN & Cactus & 0.421 & 0.119 & 0.566 & 0.248 & 0.271 & -0.039 \\
\hline Opuntia phaeacantha & $\mathrm{OPPH}$ & Cactus & 0.065 & 0.043 & 0.061 & 0.043 & 0.005 & -0.004 \\
\hline Parkinsonia florida & PAFL & Tree & 0.000 & 0.000 & 0.078 & 0.077 & 0.983 & 0.065 \\
\hline Parkinsonia microphylla & PAMI & Tree & 4.715 & 0.689 & 2.603 & 0.459 & ${ }^{2} 6.589$ & -2.498 \\
\hline Pellaea truncata & PETR & Fern & 0.000 & 0.000 & 0.010 & 0.007 & 2.240 & -0.189 \\
\hline Pennisetum ciliare & PECI & Grass & 0.175 & 0.170 & 0.011 & 0.011 & 0.965 & -0.002 \\
\hline \multirow[t]{2}{*}{ Penstemon sp. } & Penst sp & Forb & NA & NA & NA & NA & NA & NA \\
\hline & PESU & Forb & 0.002 & 0.002 & 0.000 & 0.000 & 1.801 & 0.012 \\
\hline Pleuraphis mutica & PLMU & Grass & 0.040 & 0.027 & 0.170 & 0.170 & 0.554 & 0.104 \\
\hline Pleuraphis rigida & PLRI & Grass & 0.830 & 0.201 & 1.960 & 0.554 & ${ }^{3} 3.584$ & 1.057 \\
\hline Porophyllum gracile & POGR & Subshrub & 0.062 & 0.031 & 0.119 & 0.047 & 0.984 & 0.095 \\
\hline
\end{tabular}






${ }^{1} P<0.01$.

${ }^{2} P<0.05$.

${ }^{3} P<0.1$. 
Table C2. Perennial plant species density values (plants per square meter) and standard errors for species measured on burned and unburned control transects at 13 fires in the Arizona Upland subdivision of the Sonoran Desert, Arizona.

[For each species, density values were averaged across transects from all fires for burned and unburned treatment groups, and these differences were then evaluated for statistical significance with Analysis of Variance (ANOVA). F-values are from one-way ANOVA with burn treatment (burned, unburned) and transect-level cover for each species. B/U, burned to unburned; $\mathrm{m}^{2}$, square meter; SE, standard error; NAs denote species measured for cover but not density]

\begin{tabular}{|c|c|c|c|c|c|c|c|c|}
\hline Species & Code & $\begin{array}{l}\text { Growth } \\
\text { form }\end{array}$ & $\begin{array}{c}\text { Burned } \\
\text { density } \\
\left(/ \mathrm{m}^{2}\right)\end{array}$ & SE & $\begin{array}{c}\text { Unburned } \\
\text { density } \\
\left(/ \mathrm{m}^{2}\right) \\
\end{array}$ & SE & F-value & $\begin{array}{l}B / U \\
\text { ratio }\end{array}$ \\
\hline & & & 0.003 & 0.002 & 0.003 & 0.001 & 0.029 & 1.128 \\
\hline Acacia constricta & $\mathrm{ACCO}$ & Shrub & 0.002 & 0.001 & 0.003 & 0.002 & 0.199 & 0.645 \\
\hline Acacia greggii & ACGR & Shrub & 0.021 & 0.005 & 0.035 & 0.007 & 2.437 & 0.613 \\
\hline Acamptopappus sphaerocephalus & ACSP & Shrub & 0.000 & 0.000 & 0.009 & 0.007 & 1.618 & 0.050 \\
\hline Achnatherum speciosum & ACHSPE & Grass & 0.018 & 0.007 & 0.080 & 0.037 & ${ }^{3} 2.787$ & 0.222 \\
\hline Acourtia wrightii & ACWR & Shrub & 0.001 & 0.001 & 0.000 & 0.000 & 0.180 & 1.936 \\
\hline Adenophyllum porophylloides & $\mathrm{ADPO}$ & Subshrub & 0.135 & 0.034 & 0.026 & 0.005 & ${ }^{1} 9.729$ & 5.234 \\
\hline Agave sp. & Agave & Succulent & 0.010 & 0.006 & 0.009 & 0.004 & 0.007 & 1.068 \\
\hline Allionia sp. & Allio sp & Forb & 0.004 & 0.003 & 0.005 & 0.005 & 0.038 & 0.773 \\
\hline Aloysia wrightii & ALWR & Shrub & 0.001 & 0.001 & 0.000 & 0.000 & 0.302 & 1.936 \\
\hline Ambrosia deltoidea & AMDE & Shrub & 0.065 & 0.019 & 0.189 & 0.050 & ${ }^{2} 5.628$ & 0.341 \\
\hline Ambrosia dumosa & AMDU & Shrub & 0.002 & 0.001 & 0.009 & 0.005 & 2.242 & 0.204 \\
\hline \multirow[t]{2}{*}{ Aristida ternipes } & ARTE & Grass & 0.003 & 0.002 & 0.000 & 0.000 & 1.154 & 6.766 \\
\hline & ARPU & Grass & 0.463 & 0.103 & 0.342 & 0.110 & 0.646 & 1.354 \\
\hline Artemisia ludoviciana & ARLU & Forb & 0.020 & 0.011 & 0.002 & 0.001 & 2.585 & 8.511 \\
\hline Astragalus amphioxys & ASAM & Forb & 0.000 & 0.000 & 0.007 & 0.006 & 1.368 & 0.000 \\
\hline Ayenia sp. & Ayenia & Subshrub & 0.098 & 0.035 & 0.114 & 0.059 & 0.053 & 0.862 \\
\hline Baileya multiradiata & BAMU & Forb & 0.015 & 0.015 & 0.002 & 0.002 & 0.763 & 6.574 \\
\hline Bebbia juncea & BEJU & Shrub & 0.016 & 0.008 & 0.001 & 0.001 & ${ }^{2} 3.748$ & 17.404 \\
\hline Boechera perennans & BOPE & Forb & 0.010 & 0.005 & 0.010 & 0.004 & 0.000 & 1.010 \\
\hline Bouteloua curtipendula & BOCU & Grass & 0.020 & 0.008 & 0.024 & 0.010 & 0.130 & 0.817 \\
\hline Bouteloua eriopoda & BOER & Grass & 0.103 & 0.051 & 0.076 & 0.035 & 0.192 & 1.362 \\
\hline Bouteloua hirsuta & $\mathrm{BOHI}$ & Grass & 0.000 & 0.000 & 0.004 & 0.004 & 1.036 & 0.000 \\
\hline Bouteloua repens & BORE & Grass & 0.000 & 0.000 & 0.006 & 0.006 & 1.036 & 0.000 \\
\hline Brickellia sp. & Brickellia & Shrub & 0.002 & 0.002 & 0.002 & 0.001 & 0.001 & 0.966 \\
\hline Calliandra eriophylla & CAER & Shrub & 0.340 & 0.070 & 0.254 & 0.058 & 0.881 & 1.338 \\
\hline Calochortus sp. & Caloc & Forb & 0.035 & 0.016 & 0.015 & 0.008 & 1.240 & 2.368 \\
\hline Canotia holacantha & $\mathrm{CAHO}$ & Shrub & 0.250 & 0.132 & 0.223 & 0.104 & 0.024 & 1.121 \\
\hline Carnegia gigantea & CAGI & Cactus & 0.003 & 0.001 & 0.004 & 0.002 & 0.596 & 0.644 \\
\hline Ceanothus greggii & CEGR & Shrub & 0.000 & 0.000 & 0.002 & 0.001 & 1.669 & 0.000 \\
\hline Cercocarpus montanus & CEMO & Shrub & 0.000 & 0.000 & 0.007 & 0.005 & 1.516 & 0.068 \\
\hline Chamaesyce sp. & Cham & Forb & 0.817 & 0.218 & 0.401 & 0.103 & ${ }^{3} 2.908$ & 2.038 \\
\hline Cheilanthes sp. & Cheil & Fern & 0.001 & 0.001 & 0.007 & 0.004 & 1.700 & 0.138 \\
\hline
\end{tabular}




\begin{tabular}{|c|c|c|c|c|c|c|c|c|}
\hline Species & Code & $\begin{array}{l}\text { Growth } \\
\text { form }\end{array}$ & $\begin{array}{c}\text { Burned } \\
\text { density } \\
\left(/ \mathrm{m}^{2}\right) \\
\end{array}$ & SE & $\begin{array}{c}\text { Unburned } \\
\text { density } \\
\left(/ \mathrm{m}^{2}\right) \\
\end{array}$ & SE & F-value & $\begin{array}{l}\mathrm{B} / \mathrm{U} \\
\text { ratio }\end{array}$ \\
\hline Cirsium neomexicanum & CINE & Forb & 0.002 & 0.001 & 0.001 & 0.001 & 0.364 & 1.936 \\
\hline Cottsia gracilis & COGR & Subshrub & 0.114 & 0.029 & 0.081 & 0.017 & 0.937 & 1.404 \\
\hline Crossosoma bigelovii & CRBI & Shrub & 0.000 & 0.000 & 0.002 & 0.002 & 0.941 & 0.191 \\
\hline Cylindropuntia acanthocarpa & CYAC & Cactus & 0.040 & 0.007 & 0.094 & 0.018 & ${ }^{1} 8.05$ & 0.432 \\
\hline Cylindropuntia bigelovii & CYBI & Cactus & 0.034 & 0.025 & 0.200 & 0.113 & 2.109 & 0.170 \\
\hline Cylindropuntia fulgida & CYFU & Cactus & NA & NA & NA & NA & NA & NA \\
\hline Dalea mollis & DAMO & Subshrub & 0.078 & 0.049 & 0.018 & 0.011 & 1.332 & 4.236 \\
\hline Dasyochloa pulchella & DAPU & Grass & 0.028 & 0.013 & 0.025 & 0.009 & 0.028 & 1.109 \\
\hline Delphinium $s p$ & Delph sp & Forb & 0.008 & 0.004 & 0.005 & 0.004 & 0.249 & 1.579 \\
\hline Dichelostemma capitatum & DICA & Forb & 0.249 & 0.093 & 0.029 & 0.010 & ${ }^{2} 5.304$ & 8.660 \\
\hline Ditaxis lanceolata & DILA & Forb & 0.023 & 0.009 & 0.014 & 0.005 & 0.861 & 1.642 \\
\hline Ditaxis neomexicana & DINE & Forb & 0.048 & 0.025 & 0.070 & 0.034 & 0.278 & 0.685 \\
\hline Dodonaea viscosa & DOVI & Shrub & 0.001 & 0.001 & 0.000 & 0.000 & 0.302 & 1.936 \\
\hline Dudleya saxosa & DUSA & Succulent & 0.000 & 0.000 & 0.009 & 0.009 & 1.036 & 0.000 \\
\hline Echinocereus engelmannii & ECEN & Cactus & 0.012 & 0.003 & 0.037 & 0.009 & ${ }^{17} 7.401$ & 0.322 \\
\hline Echinocereus sp. & Echino sp & Cactus & 0.001 & 0.001 & 0.001 & 0.001 & 0.001 & 0.968 \\
\hline Echinomastus johnsonii & ECJO & Cactus & 0.000 & 0.000 & 0.002 & 0.001 & 1.070 & 0.239 \\
\hline Elymus elymoides & ELEL & Grass & 0.000 & 0.000 & 0.005 & 0.004 & 1.266 & 0.000 \\
\hline Encelia farinosa & ENFA & Shrub & 0.624 & 0.124 & 0.289 & 0.072 & ${ }^{2} 5.356$ & 2.158 \\
\hline Encelia frutescens & ENFR & Shrub & 0.031 & 0.015 & 0.009 & 0.004 & 1.790 & 3.285 \\
\hline Encelia virginensis & ENVI & Shrub & 0.029 & 0.015 & 0.014 & 0.006 & 0.825 & 2.098 \\
\hline Ephedra aspera & EPAS & Shrub & 0.001 & 0.001 & 0.002 & 0.001 & 0.564 & 0.484 \\
\hline Ephedra fasciculata & EPFA & Shrub & 0.000 & 0.000 & 0.002 & 0.002 & 2.390 & 0.000 \\
\hline Ephedra nevadensis & EPNE & Shrub & 0.002 & 0.001 & 0.005 & 0.002 & 1.162 & 0.482 \\
\hline Ephedra sp. & Ephedra & Shrub & 0.001 & 0.001 & 0.006 & 0.003 & 1.781 & 0.161 \\
\hline Ephedra viridis & EPVI & Shrub & 0.023 & 0.023 & 0.094 & 0.083 & 0.708 & 0.244 \\
\hline Ericameria braychylepis & ERBR & Shrub & 0.000 & 0.000 & 0.004 & 0.004 & 1.036 & 0.000 \\
\hline Ericameria laricifolia & ERLA & Shrub & 0.005 & 0.004 & 0.037 & 0.015 & ${ }^{2} 4.346$ & 0.147 \\
\hline Ericameria linearifolia & ERLI & Shrub & 0.001 & 0.001 & 0.012 & 0.009 & 1.733 & 0.074 \\
\hline Ericameria sp. & Ericameria & Shrub & 0.003 & 0.001 & 0.014 & 0.006 & 3.276 & 0.193 \\
\hline Erigeron concinnus & ERCO & Forb & 0.004 & 0.004 & 0.000 & 0.000 & 0.966 & NA \\
\hline Eriogonum fasciculatum & ERFA & Shrub & 0.134 & 0.035 & 0.379 & 0.060 & ${ }^{1} 12.62$ & 0.354 \\
\hline Eriogonum inflatum & ERIN & Forb & 0.134 & 0.066 & 0.126 & 0.050 & 0.010 & 1.067 \\
\hline Eriogonum wrightii & ERWR & Shrub & 0.110 & 0.041 & 0.088 & 0.041 & 0.152 & 1.255 \\
\hline Euphorbia eriantha & EUER & Forb & 0.001 & 0.001 & 0.001 & 0.001 & 0.076 & 1.447 \\
\hline Evolvulus nuttallianus & EVNU & Forb & 0.017 & 0.017 & 0.001 & 0.001 & 0.853 & 12.248 \\
\hline Fagonia laevis & FALA & Subshrub & 0.068 & 0.049 & 0.039 & 0.021 & 0.294 & 1.755 \\
\hline Ferocactus cylindraceus & FECY & Cactus & 0.003 & 0.001 & 0.008 & 0.003 & ${ }^{3} 3.346$ & 0.375 \\
\hline Fouquieria splendens & FOSP & Shrub & 0.004 & 0.002 & 0.008 & 0.002 & 1.979 & 0.511 \\
\hline Galium stellatum & GAST & Shrub & 0.026 & 0.009 & 0.022 & 0.008 & 0.113 & 1.192 \\
\hline
\end{tabular}




\begin{tabular}{|c|c|c|c|c|c|c|c|c|}
\hline Species & Code & $\begin{array}{l}\text { Growth } \\
\text { form }\end{array}$ & $\begin{array}{c}\text { Burned } \\
\text { density } \\
\left(/ \mathrm{m}^{2}\right)\end{array}$ & SE & $\begin{array}{c}\text { Unburned } \\
\text { density } \\
\left(/ \mathrm{m}^{2}\right) \\
\end{array}$ & SE & F-value & $\begin{array}{l}B / U \\
\text { ratio }\end{array}$ \\
\hline Gaura sp. & Gaura.sp & Forb & 0.000 & 0.000 & 0.001 & 0.001 & 1.036 & 0.000 \\
\hline Gutierrezia sarothrae & GUSA & Subshrub & 0.140 & 0.040 & 0.072 & 0.023 & 2.168 & 1.951 \\
\hline Hibiscus coulteri & $\mathrm{HICO}$ & Shrub & 0.007 & 0.004 & 0.001 & 0.001 & 1.746 & 4.837 \\
\hline Horsfordia sp. & Hors sp & Subshrub & 0.001 & 0.001 & 0.000 & 0.000 & 0.966 & NA \\
\hline Hybanthus verticillatus & HYVE & Forb & 0.004 & 0.002 & 0.002 & 0.001 & 0.453 & 1.740 \\
\hline Hymenoclea salsola & HYSA & Shrub & 0.001 & 0.001 & 0.002 & 0.002 & 0.066 & 0.723 \\
\hline Hyptis emoryi & HYEM & Shrub & 0.008 & 0.004 & 0.000 & 0.000 & ${ }^{2} 3.748$ & 17.404 \\
\hline Justicia longii & JULO & Forb & 0.007 & 0.005 & 0.008 & 0.003 & 0.014 & 0.906 \\
\hline Keckiella antirrhinoides & KEAN & Shrub & 0.001 & 0.001 & 0.000 & 0.000 & 0.180 & 1.936 \\
\hline Krameria erecta & KRER & Shrub & 0.095 & 0.029 & 0.061 & 0.014 & 1.119 & 1.557 \\
\hline Krameria grayi & KRGR & Shrub & 0.002 & 0.001 & 0.007 & 0.003 & ${ }^{3} 2.749$ & 0.258 \\
\hline Krameria sp. & Krameria & Shrub & NA & NA & NA & NA & NA & NA \\
\hline Larrea tridentata & LATR & Shrub & 0.015 & 0.004 & 0.037 & 0.009 & ${ }^{2} 5.355$ & 0.391 \\
\hline Lotus rigidus & LORI & Forb & 0.125 & 0.034 & 0.048 & 0.013 & ${ }^{2} 4.308$ & 2.588 \\
\hline Lycium berlandieri & LYBE & Shrub & 0.003 & 0.002 & 0.001 & 0.001 & 0.944 & 2.255 \\
\hline Lycium exsertum & LYEX & Shrub & 0.010 & 0.006 & 0.006 & 0.003 & 0.393 & 1.770 \\
\hline Lycium sp. & Lycium & Shrub & 0.008 & 0.003 & 0.010 & 0.003 & 0.317 & 0.790 \\
\hline Mammillaria grahamii & MAGR & Cactus & 0.007 & 0.002 & 0.009 & 0.002 & 0.437 & 0.773 \\
\hline Mammillaria sp. & Mamm sp & Cactus & 0.001 & 0.001 & 0.000 & 0.000 & 0.180 & 1.936 \\
\hline Matelea parvifolia & MAPA & Forb & 0.015 & 0.007 & 0.013 & 0.006 & 0.064 & 1.180 \\
\hline Melampodium leucanthum & MELE & Forb & 0.031 & 0.014 & 0.046 & 0.025 & 0.271 & 0.677 \\
\hline Menodora scabra & MESC & Subshrub & 0.067 & 0.021 & 0.117 & 0.040 & 1.281 & 0.570 \\
\hline Metastelma arizonicum & MEAR & Forb & 0.002 & 0.001 & 0.003 & 0.001 & 0.349 & 0.645 \\
\hline Mirabilis laevis & MILA & Forb & 0.040 & 0.009 & 0.033 & 0.008 & 0.414 & 1.228 \\
\hline Muhlenbergia porteri & MUPO & Grass & 0.006 & 0.003 & 0.019 & 0.007 & ${ }^{3} 2.79$ & 0.338 \\
\hline Nolina bigelovii & NOBI & Shrub & 0.002 & 0.002 & 0.005 & 0.004 & 0.372 & 0.482 \\
\hline Nolina microcarpa & NOMI & Shrub & 0.005 & 0.005 & 0.000 & 0.000 & 1.142 & NA \\
\hline Opuntia chlorotica & $\mathrm{OPCH}$ & Cactus & 0.000 & 0.000 & 0.001 & 0.001 & 0.428 & 0.319 \\
\hline Opuntia engelmannii & OPEN & Cactus & 0.022 & 0.010 & 0.032 & 0.011 & 0.425 & 0.696 \\
\hline Opuntia phaeacantha & OPPH & Cactus & 0.001 & 0.001 & 0.006 & 0.004 & 1.743 & 0.222 \\
\hline Parkinsonia florida & PAFL & Tree & 0.001 & 0.001 & 0.001 & 0.001 & 0.093 & 1.447 \\
\hline Parkinsonia microphylla & PAMI & Tree & 0.046 & 0.007 & 0.021 & 0.004 & ${ }^{1} 9.29$ & 2.168 \\
\hline Pellaea truncata & PETR & Fern & 0.017 & 0.006 & 0.005 & 0.002 & ${ }^{2} 4.549$ & 3.667 \\
\hline Pennisetum ciliare & PECI & Grass & 0.000 & 0.000 & 0.012 & 0.011 & 1.036 & 0.038 \\
\hline \multirow[t]{2}{*}{ Penstemon sp. } & Penst sp & Forb & 0.003 & 0.002 & 0.002 & 0.001 & 0.120 & 1.452 \\
\hline & PESU & Forb & 0.003 & 0.002 & 0.000 & 0.000 & 1.585 & 6.766 \\
\hline Pleuraphis mutica & PLMU & Grass & 0.026 & 0.026 & 0.019 & 0.011 & 0.053 & 1.368 \\
\hline Pleuraphis rigida & PLRI & Grass & 0.453 & 0.112 & 0.342 & 0.084 & 0.622 & 1.325 \\
\hline Porophyllum gracile & POGR & Subshrub & 0.074 & 0.021 & 0.032 & 0.013 & ${ }^{3} 2.72$ & 2.301 \\
\hline Prosopis velutina & PRVE & Tree & NA & NA & NA & NA & NA & NA \\
\hline
\end{tabular}




\begin{tabular}{|c|c|c|c|c|c|c|c|c|}
\hline Species & Code & $\begin{array}{l}\text { Growth } \\
\text { form }\end{array}$ & $\begin{array}{c}\text { Burned } \\
\text { density } \\
\left(/ \mathrm{m}^{2}\right)\end{array}$ & SE & $\begin{array}{c}\text { Unburned } \\
\text { density } \\
\left(/ \mathrm{m}^{2}\right)\end{array}$ & SE & F-value & $\begin{array}{l}B / U \\
\text { ratio }\end{array}$ \\
\hline Psilostrophe cooperi & PSCO & Subshrub & 0.015 & 0.009 & 0.010 & 0.005 & 0.232 & 1.518 \\
\hline Quercus turbinella & QUTU & Shrub & 0.004 & 0.004 & 0.008 & 0.008 & 0.252 & 0.455 \\
\hline Salazaria mexicana & SAME & Shrub & 0.051 & 0.020 & 0.085 & 0.039 & 0.618 & 0.598 \\
\hline Salvia mohavensis & SAMO & Shrub & 0.003 & 0.003 & 0.000 & 0.000 & 0.966 & NA \\
\hline Senna covesii & SECO & Forb & 0.182 & 0.105 & 0.043 & 0.020 & 1.646 & 4.246 \\
\hline Simmondsia chinensis & $\mathrm{SICH}$ & Shrub & 0.065 & 0.012 & 0.101 & 0.023 & 1.916 & 0.642 \\
\hline Sphaeralcea ambigua & SPAM & Forb & 0.082 & 0.021 & 0.040 & 0.008 & ${ }^{3} 3.318$ & 2.070 \\
\hline Sporobolus cryptandrus & SPCR & Grass & 0.002 & 0.002 & 0.008 & 0.006 & 0.667 & 0.301 \\
\hline Stephanomeria sp. & Steph & Subshrub & 0.052 & 0.015 & 0.017 & 0.004 & ${ }^{2} 4.699$ & 3.086 \\
\hline Thamnosma montana & THMO & Shrub & 0.000 & 0.000 & 0.005 & 0.004 & 1.218 & 0.087 \\
\hline Tridens muticus & TRMU & Grass & 0.070 & 0.022 & 0.079 & 0.037 & 0.040 & 0.891 \\
\hline Trixis californica & TRCA & Subshrub & 0.004 & 0.002 & 0.006 & 0.004 & 0.136 & 0.724 \\
\hline Viguiera parishii & VIPA & Shrub & 0.119 & 0.028 & 0.116 & 0.031 & 0.003 & 1.021 \\
\hline \multirow[t]{2}{*}{ Xanthisma spinulosum } & XASP & Forb & 0.057 & 0.025 & 0.049 & 0.034 & 0.036 & 1.161 \\
\hline & XYTO & Subshrub & 0.001 & 0.001 & 0.002 & 0.001 & 0.143 & 0.723 \\
\hline Yucca baccata & YUBA & Shrub & 0.004 & 0.002 & 0.017 & 0.006 & ${ }^{2} 4.595$ & 0.215 \\
\hline Ziziphus obtusifolia & $\mathrm{ZIOB}$ & Shrub & NA & NA & NA & NA & NA & NA \\
\hline
\end{tabular}

${ }^{1} P<0.01$.

${ }^{2} P<0.05$.

${ }^{3} P<0.1$. 


\section{Appendix D. Frequencies of Invasive Annual Species Observed}

Table D1. Frequencies (presence/absence) of invasive annual plant species observed on burned or unburned transects at 9 fires in Arizona Upland Subdivision vegetation of the Sonoran Desert, Arizona.

[Frequencies were calculated as the percentage occurrence of each species across 25 quadrats per transect. For each fire, frequency values were averaged across transects in each treatment (burned, unburned). F-values are from one-way Analysis of Variance (ANOVA) with burn treatment (burned, unburned) and transectlevel species frequencies. SE, standard error]

\begin{tabular}{|c|c|c|c|c|c|c|c|c|c|c|c|c|c|c|c|c|}
\hline \multirow{2}{*}{ Fire } & \multirow{2}{*}{ Year } & \multicolumn{5}{|c|}{ Bromus rubens } & \multicolumn{5}{|c|}{ Schismus spp. } & \multicolumn{5}{|c|}{ Erodium cicutarium } \\
\hline & & Burned & SE & Unburned & SE & F-value & Burned & SE & Unburned & SE & F-value & Burned & SE & Unburned & SE & F-value \\
\hline Arrastra & 1999 & 84.000 & 10.583 & 70.857 & 13.114 & 0.580 & 16.667 & 8.728 & 48.571 & 14.221 & 3.356 & 50.000 & 14.413 & 32.000 & 12.313 & 0.914 \\
\hline Harcuvar & 1999 & 81.000 & 8.726 & 86.667 & 7.775 & 0.235 & 5.667 & 3.132 & 6.333 & 2.932 & 0.024 & 15.000 & 5.660 & 17.000 & 7.154 & 0.048 \\
\hline Harquahala & 1993 & 52.667 & 20.302 & 21.333 & 10.311 & 1.894 & 6.000 & 3.830 & 2.000 & 1.366 & 0.968 & 9.333 & 9.333 & 0.667 & 0.667 & 0.858 \\
\hline Hualapai & 1980 & 98.667 & 0.843 & 91.333 & 7.186 & 1.027 & 0.000 & 0.000 & 0.000 & 0.000 & $\mathrm{~N} / \mathrm{A}$ & 15.333 & 12.411 & 0.667 & 0.667 & 1.392 \\
\hline Nuke & 2005 & 0.000 & 0.000 & 0.000 & 0.000 & N/A & 32.000 & 7.448 & 16.000 & 7.155 & 2.400 & 0.000 & 0.000 & 0.000 & 0.000 & $\mathrm{~N} / \mathrm{A}$ \\
\hline Rock & 1989 & 88.000 & 7.589 & 91.200 & 7.838 & 0.086 & 0.800 & 0.800 & 0.000 & 0.000 & 1.000 & 32.800 & 20.877 & 4.000 & 4.000 & 1.836 \\
\hline San Tan & 1993 & 0.400 & 0.400 & 0.000 & 0.000 & 0.790 & 42.400 & 8.500 & 55.000 & 10.050 & 0.928 & 29.600 & 7.035 & 12.000 & 5.071 & ${ }^{3} 3.737$ \\
\hline Wades & 1980 & 40.667 & 16.344 & 39.200 & 13.351 & 0.005 & 4.667 & 1.909 & 33.600 & 20.576 & 2.396 & 0.000 & 0.000 & 7.200 & 6.248 & 1.630 \\
\hline $\begin{array}{l}\text { White } \\
\text { Canyon }\end{array}$ & 1995 & 33.714 & 13.989 & 27.333 & 14.364 & 0.100 & 3.429 & 3.429 & 54.000 & 15.449 & ${ }^{1} 11.88$ & 50.286 & 15.635 & 50.000 & 18.265 & 0.000 \\
\hline All Fires & & 51.687 & 5.560 & 49.640 & 5.540 & 0.068 & 13.687 & 2.608 & 23.870 & 4.170 & ${ }^{2} 4.373$ & 22.500 & 3.864 & 14.557 & 3.302 & 2.421 \\
\hline
\end{tabular}

${ }^{1} P<0.01$.

${ }^{2} P<0.05$.

${ }^{3} P<0.1$. 
Publishing support provided by the U.S. Geological Survey

Science Publishing Network, Tacoma Publishing Service Center

For more information concerning the research in this report, contact the Director, Western Ecological Research Center

U.S. Geological Survey

3020 State University Drive East

Sacramento, California 95819

http://werc.usgs.gov/ 
